UNIVERSIDADE DE SÃO PAULO

FACULDADE DE FILOSOFIA, LETRAS E CIÊNCIAS HUMANAS

DEPARTAMENTO DE LETRAS CLÁSSICAS E VERNÁCULAS

PROGRAMA DE PÓS-GRADUAÇÃO EM FILOLOGIA E LÍNGUA PORTUGUESA

\title{
OS GÊNEROS DISCURSIVOS NO LIVRO DIDÁTICO DO ENSINO MÉDIO
}

Lucimar Regina Santana Rodrigues 
UNIVERSIDADE DE SÃO PAULO

FACULDADE DE FILOSOFIA, LETRAS E CIÊNCIAS HUMANAS

DEPARTAMENTO DE LETRAS CLÁSSICAS E VERNÁCULAS

PROGRAMA DE PÓS-GRADUAÇÃO EM FILOLOGIA E LÍNGUA PORTUGUESA

\section{OS GÊNEROS DISCURSIVOS NO LIVRO DIDÁTICO DO ENSINO MÉDIO}

Lucimar Regina Santana Rodrigues

Dissertação apresentada ao Programa de PósGraduação em Filologia e Língua Portuguesa, do Departamento de Letras Clássicas e Vernáculas da Faculdade de Filosofia, Letras e Ciências Humanas da Universidade de São Paulo, para obtenção do título de Mestre em Letras.

Orientadora: Profa. Dra. Maria Lúcia da Cunha Victório de Oliveira Andrade

São Paulo

2007 
Ao meu esposo Márcio aos meus filhos Ana Paula e Caio e aos meus pais queridos 


\section{AGRADECIMENTOS}

A Deus, por me impulsionar e não permitir que eu desistisse por mais doloroso que fosse o momento.

A minha orientadora, Profa.Dra. Maria Lúcia da Cunha Victório de Oliveira Andrade, pela dedicação e paciência durante todo processo de meu mestrado.

Às professoras Dra. Elisa Guimarães e Dra.Sueli Cristina Marquesi pelas contribuições teóricas na banca de qualificação.

A todos os professores da USP que contribuíram de forma direta na concretização deste sonho.

A toda minha família, pelo carinho e incentivo e a minha irmã Valdirene que infelizmente não pôde partilhar diretamente deste meu momento ímpar.

Aos amigos Saul, Célia, Kelly e muitos outros pela força e pela vibração positiva. 
"O irrealizável de um sonho está na inércia de quem sonha."

(Anônimo) 


\section{RESUMO}

No presente estudo, analisamos os gêneros discursivos no livro didático do Ensino Médio e a perspectiva de uma abordagem adequada das modalidades oral e escrita da língua portuguesa. O aluno do Ensino Médio tem de saber fazer uso eficaz da linguagem em qualquer instância de sua vida, o que compreende a habilidade de leitura, interpretação, produção e adequação dos diferentes gêneros do discurso com os quais ele se defronta nas mais variadas situações sociais. Para que o aluno tenha acesso aos diferentes gêneros discursivos, um dos facilitadores é, sem dúvida, o livro didático. O livro didático tem desempenhado papel importante no dia-a-dia educacional. Merece muitas críticas sobre sua qualidade e sua utilização em sala de aula, mas constitui-se, muitas vezes, na principal ferramenta de trabalho do professor e no suporte pelo qual o aluno entra em contato com os diversos textos nas modalidades oral e escrita da língua. Os livros didáticos apresentam uma grande variedade de gêneros discursivos, mas e a exploração desses gêneros? Os exercícios propostos para o estudo dos textos estão levando o aluno a perceber aqueles que estão relacionados às situações de comunicação oral e imediata e aqueles que estão relacionados às situações mais complexas? Partindo da análise das propostas de três livros didáticos do primeiro ano do Ensino Médio, observamos e discutimos como os gêneros discursivos são abordados no primeiro ano do Ensino Médio, a partir da perspectiva teórica de Bakhtin, Bronckart, Brandão, Marcuschi e outros.

Palavras-chave: Gêneros discursivos. Livro didático. Aluno. Ensino Médio. 


\begin{abstract}
In the following study we will analyze the types of speech in high school workbooks and the perspective of an appropriate approach regarding the verbal and written modalities of the Portuguese language. The high school student must know how to efficiently use the language in every aspect of his/her life. This means the ability to read, interpret, produce and adapt to the different types of speech in which he/she will encounter in the most varied of social situations. Without a doubt, it is much easier for the student to gain access to the different types of speech with workbooks. The workbook has a very important role in day-to-day education. Criticism is often deserved in respect to the quality and utilization of workbooks in the classroom, but many times they are the main tool that the teacher has as well as being the main support by which the student has contact with the various types of text in the verbal and written modalities of the language. The workbooks present a large variety of speech types, but how can these different types be explored? Are the proposed exercises for the study of texts allowing the student to understand those that are related to immediate and verbal communication situations as well as those that are related to more complex situations? Starting from the analysis of three proposed high school workbooks, we will observe and discuss how the speech types are approached in the first year of high school from the theoretical perspectives of Bakhtin, Bronckart, Brandão, Marcuschi and others.
\end{abstract}

Key Words: Speech types. Workbooks. Student. High School. 


\section{Lista de figuras}

Figura 1.1 Dimensões dos gêneros do discurso...................................... 19

\section{Lista de gráficos}

Gráfico 3.1 Gêneros contemplados na unidade 1

Gráfico 3.2 Gêneros contemplados na unidade 2

Gráfico 3.3 Gêneros contemplados na unidade 3

Gráfico 3.4 Gêneros contemplados na unidade 4

Gráfico 3.5 Gêneros contemplados na unidade 5

Gráfico 3.6 Gêneros contemplados na unidade 6

Gráfico 3.7 Gêneros contemplados na unidade 7

Gráfico 3.8 Gêneros contemplados na unidade 8

Gráfico 3.9 Gêneros contemplados na unidade 9 .

Gráfico 3.10 Gêneros contemplados na unidade 10

Gráfico 3.11 Gêneros contemplados na unidade 11

Gráfico 3.12 Gêneros discursivos no livro Língua e Literatura ............................ 63

Gráfico 3.13 Gêneros contemplados na parte 1 ............................................ 66

Gráfico 3.14 Gêneros contemplados na parte 2........................................... 67

Gráfico 3.15 Gêneros contemplados na parte 3............................................. 68

Gráfico 3.16 Gêneros discursivos no livro Língua, Literatura e Produção de Texto 69

Gráfico 3.17 Gêneros contemplados na parte 1 …………………………...... 72

Gráfico 3.18 Gêneros contemplados na parte 2 …………........................... 73

Gráfico 3.19 Gêneros contemplados na parte 3 ……................................... 74

Gráfico 3.20 Gêneros contemplados na parte 4 ………................................. 75

Gráfico 3.21 Gêneros discursivos no livro Português Linguagens ....................... 76

\section{Lista de quadros}

Quadro 1.1 Representação das seqüências .................................................. 24

Quadro 1.2 Aspectos tipológicos dos gêneros discursivos ................................... 28

Quadro 1.3 Representação dos gêneros textuais …………………………...... 30

Quadro 4.1 Condições de produções de oralidade e escrita ................................ 80

\section{Lista de tabelas}

Tabela 3.1 Gêneros discursivos no livro Língua e Literatura ............................... 56

Tabela 3.2 Gêneros discursivos no livro Língua, Literatura e Produção de Texto .. 65

Tabela 3.3 Gêneros discursivos no livro Português Linguagens 


\section{SUMÁRIO}

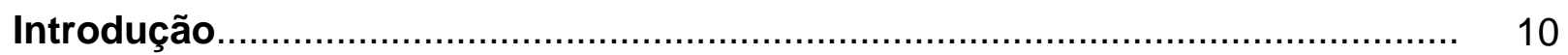

1 Gêneros discursivos: classificações e concepções ..................................... 18

1.1 Os gêneros discursivos em Bakhtin ........................................................... 18

1.2 Os gêneros discursivos em Bronckart ...................................................... 21

1.3 Os gêneros discursivos na perspectiva de Brandão ...................................... 25

1.4 Outras formas de classificação do gênero ..................................................... 27

1.5 Os gêneros discursivos em PCN do Ensino Médio ......................................... 31

20 livro didático: uma breve revisão ....................................................... 34

2.1 Perspectivas histórica e política ……………………............................... 34

2.2 O papel do livro didático …………...................................................... 37

2.3 O livro didático de português........................................................................ 39

2.3.1 Origem e evolução do livro didático de português ....................................... 40

2.3.2 O livro didático de português segundo o Catálogo do Programa Nacional do Livro para o Ensino Médio - PNLEM/2005 ……………..................................... 42

2.4 O gênero discursivo no Manual do Professor do livro didático do Ensino Médio.

45

2.4.1 O Manual do Professor ............................................................................. 45

2.4.2 O Manual do Professor do livro Língua e Literatura ................................... 47

2.4.3 O Manual do Professor do livro Língua, Literatura e Produção de Textos ...... 50

2.4.4 O Manual do Professor do livro Português Linguagens ................................ 52

3 A circulação dos gêneros discursivos nos livros didáticos selecionados .... 55

3.1 Língua e Literatura .......................................................................... 55

3.2 Língua, Literatura e Produção de Textos .................................................... 64

3.3 Português Linguagens ........................................................................ 69

4 Os gêneros discursivos no livro didático: Análise do corpus ........................ 77

4.1 Língua e Literatura ................................................................................ 77

4.2 Língua, Literatura e Produção de Textos .................................................... 82

4.3 Português Linguagens ...................................................................... 87

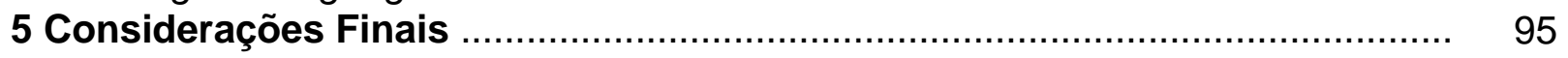

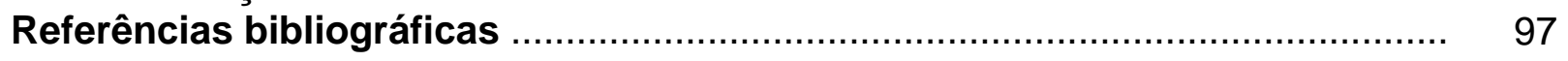

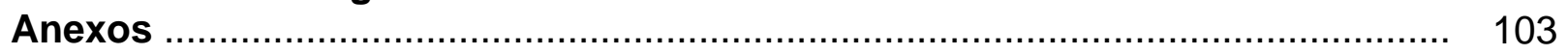




\section{INTRODUÇÃO}

O desenvolvimento da habilidade de leitura no aprendiz é o grande desafio da educação contemporânea. Tal habilidade engloba o uso adequado da linguagem, pois é por meio dela que as pessoas se comunicam, expressam e defendem suas idéias, constroem e dividem experiências e produzem cultura.

O aluno do ensino médio tem de saber fazer uso eficaz da linguagem em qualquer instância de sua vida, o que compreende a habilidade de leitura, interpretação, produção e adequação dos diferentes gêneros discursivos com os quais ele se defronta nas mais variadas situações sociais.

O que é a Leitura? Este é também um questionamento do autor francês Bellenger (apud COSTE, 1997, p.17)

Em que se baseia a leitura? No desejo. Esta resposta é uma opção. É
tanto o resultado de uma observação como de uma intuição vivida. Ler é
identificar-se com o apaixonado ou com o místico. É ser um pouco
clandestino, é abolir o mundo exterior, deportar-se para uma ficção, abrir
o parêntese do imaginário. Ler é muitas vezes trancar-se (no sentido
próprio e figurado). É manter uma ligação através do tato, do olhar, até
mesmo do ouvido (as palavras ressoam). As pessoas lêem com seus
corpos. Ler é também sair transformado de uma experiência de vida, é
esperar alguma coisa. É um sinal de vida, um apelo, uma ocasião de
amar sem a certeza de que se vai amar. Pouco a pouco o desejo
desaparece sob o prazer.

Apesar de ser uma atividade tão importante e crucial em nossa sociedade, a queixa mais comumente ouvida entre professores é: "Os meus alunos não gostam de ler", e é sabido que a leitura tem no cotidiano de muitos brasileiros um lugar cada vez mais insignificante. A atividade árida e tortuosa de decifração de palavras, que é chamada de leitura em sala de aula, não tem nada a ver com a atividade prazerosa descrita por Bellenger. O que é urgente saber é que, para formar leitores, deve-se despertar nas pessoas o interesse pela leitura. 
As palavras de Bakhtin (1992 [1953], p.301-302) revelam a importância que o autor dá aos gêneros discursivos e a partir delas podemos perceber a necessidade de seu aprendizado em sala de aula:

\begin{abstract}
As formas da língua e as formas típicas de enunciados, isto é, os gêneros de discurso, introduzem-se em nossa experiência e em nossa consciência conjuntamente e sem que sua estreita relação seja rompida. Aprender a falar é aprender a estruturar enunciados.
\end{abstract}

Como o aluno pode ter acesso aos diferentes gêneros discursivos?

Um dos facilitadores é, sem dúvida, o livro didático. O livro didático tem desempenhado papel importante no dia-a-dia educacional. Merece muitas críticas sobre sua qualidade e sua utilização em sala de aula, mas constitui, muitas vezes, a principal ferramenta de trabalho do professor e no suporte pelo qual o aluno entra em contato com textos escritos de gêneros diversificados.

Os gêneros discursivos são muitos e sua classificação é bastante diversificada, complexa e abrangente não havendo uma única nomenclatura para defini-los. Brandão (2000) cita, por exemplo, a distinção clássica entre poesia e prosa; a distinção entre lírico, épico e dramático, a classificação antiga entre tragédia e comédia; a teoria dos três estilos elevado, médio e humilde; a classificação da retórica antiga entre deliberativo, judiciário e epidítico; até a tipologia utilizada no campo da lingüística: as tipologias funcionais, as tipologias enunciativas, as tipologias cognitivas e a tipologia sócio-interacionista.

Que gêneros discursivos são encontrados nos livros didáticos? Como aparecem os diversos gêneros discursivos no livro didático do ensino médio? Como está sendo explorado tão rico material, que pode levar o aluno não só a aprender a ler as estratégias discursivas com que se tecem os diversos gêneros como também a desenvolver raciocínio crítico?

É sabido que da escrita à leitura e da leitura à escrita, o domínio do material gráfico suscita nas pessoas o aparecimento de necessidades novas de tipo intelectual, cultural, social, lúdico-afetivo e estético. Mas:

Para além das diferenças resultantes do diferente tipo de suporte, o oral e o escrito individualizam-se como tipos distintos de utilização da 
linguagem com especificidade própria enquanto modos alternativos de pensar a relação entre o falante e a linguagem e entre a linguagem e 0 mundo. (BASTOS, 2000, p.23)

O objetivo geral deste trabalho é contribuir para o aprofundamento de questões voltadas para o estudo dos gêneros discursivos na escola, observando quais são os gêneros presentes na sala de aula do primeiro ano do ensino médio e como são explorados no livro didático.

Os objetivos específicos são:

> abordar a pertinência dos gêneros nos estudos discursivos atuais;

> apresentar as teorias de Bakhtin, Bronckart e Brandão sobre os gêneros discursivos e verificar a sua adequação para o trabalho com o livro didático;

> investigar o ensino dos gêneros discursivos em livros didáticos do primeiro ano do ensino médio;

> examinar quais gêneros discursivos se fazem presentes na sala de aula por meio do trabalho com o livro didático;

> interpretar e analisar as estratégias e as técnicas de estudo dos gêneros discursivos apresentados nos livros didáticos selecionados.

Segundo Abreu (2000, p.11), "entre as competências necessárias para que o País continue líder mundial no próximo século, está a de gerenciamento da informação por meio da comunicação oral e escrita, ou seja, a capacidade de ler, falar e escrever bem".

Harold Bloom ${ }^{1}$, um dos mais respeitados críticos literários em atividade, diz que:

Lemos, intensamente, por várias razões, a maioria das quais conhecidas: porque, na vida real, não temos condições de 'conhecer' tantas pessoas, com tanta intimidade; porque precisamos nos conhecer melhor; porque necessitamos de conhecimento, não apenas de terceiros e de nós mesmos, mas das coisas da vida. Lemos plenamente, não para acreditar, nem para concordar, tampouco para refutar, mas para buscar empatia com a natureza que escreve e lê.

Há uma certa preocupação da educação brasileira com essa problemática, os PCN do ensino fundamental e médio, na Apresentação da Área de Língua 
Portuguesa, por exemplo, apontam os problemas do ensino da escrita e leitura, as necessidades do aluno e algumas soluções para melhoria de sua leitura e escrita.

Segundo os PCN (1999) do ensino médio no tocante ao ensino da Língua Portuguesa:

\begin{abstract}
A linguagem verbal, oral e escrita, representada pela língua materna, ocupa na área o papel de viabilizar a compreensão e o encontro dos discursos utilizados em diferentes esferas da vida social. É com e pela língua que as formas sociais arbitrárias de visão e divisão de mundo são incorporadas e utilizadas como instrumentos de conhecimento e comunicação. Aprende-se, com a língua, um "sentido imediato de mundo", que deve ser desvendado, no decorrer de um processo de resgate desse e de outros sentidos possíveis. (p.131)
\end{abstract}

Luciana Salgado, professora preparadora de textos e Projeto Editorial Cursinho da Poli e integrante do núcleo Confraria de Textos, observa o seguinte:

Se a escola se pretende formadora de seres criativos, precisa dar a ler, contar por que é bom, mostrar que leu, oferecer possibilidades de instigar comparações, o que depende de professores familiarizados com o processo, experimentados nesse exercício, com repertório farto não só de leituras canônicas, mas sobretudo de escolhas pessoais que engendram habilidades como o destemor da entrega a novos títulos e a escolhas distintas das que se tem por hábito supor evidentes. ${ }^{2}$

A isso, acrescenta Adriano Schwuartz ${ }^{3}$, na mesma matéria: "Caberia ao educador limpar terreno, destruir bloqueios bobos e medos infundados, em suma, dar uma mãozinha para que o gosto do leitor se estabeleça com mais facilidade".

Por outro lado, não se pode esquecer de que o professor está muitas vezes "engessado" no famoso livro didático. O livro didático acabou assumindo um papel central nas práticas escolares. Os diversos textos e livros de gramática, usados pelos professores até a década de 60, foram substituídos pelos livros didáticos.

Os livros didáticos passaram a ocupar um papel maior do que o de simples fornecedor de referências. Acabaram por definir o currículo, a metodologia e a até mesmo a avaliação, reduzindo assim o papel do docente, que encontrou um certo conforto no uso do livro didático, pois este passou a ser considerado mais do que um instrumento de trabalho.

\footnotetext{
${ }^{1}$ Em matéria publicada no Revista Educação, ano 28, n. 242, jun. 2001.

${ }^{2}$ RIZZO, Sérgio. Clássico é clássico. Educação, ano 28, no. 242, junho de 2001, p. 25.

${ }^{3}$ Jornalista, Doutor em Teoria Literária-USP e professor na EACH - USP Leste.
} 
Sem voz e sem poder de decisão, os alunos aprenderam a lidar com esse tipo de material, que se repete na forma de organização a cada ano, incansavelmente.

Para Batista (2001, p.24), os livros didáticos se organizam em torno:

- $\quad$ [...] da apresentação não apenas de conteúdos curriculares mas também de um conjunto de atividades para o ensino-aprendizado desses conteúdos;

- da distribuição desses conteúdos e atividades de ensino, de acordo com a progressão do tempo escolar, particularmente com as séries e unidades de ensino.

Enfim, são diversas as razões que determinam o espaço ocupado hoje pelo livro didático na escola e ele, por sua vez, desempenha um papel de destaque na veiculação de textos e na formação de opinião dos alunos.

A partir da premissa e da importância de se trabalhar com diferentes tipos de textos ao longo do período escolar, os livros didáticos e os professores passaram a apresentar, aos seus alunos, diferentes tipos de textos, apesar de nem sempre explorá-los da forma adequada, conforme destaca Chiapini (2000, p.10):

[...] textos dos mais diversos gêneros e funções distintos, verbais ou não verbais, poéticos ou não, são trabalhados nas escolas observadas, segundo sugestões dos manuais didáticos. Da mesma maneira, os exercícios que a eles se aplicam são quase idênticos, o que na maior parte das vezes leva alunos e professores a leituras demasiadamente limitadas, pouco críticas e criativas, quando não totalmente inadequadas ou equivocadas, limitando também o conhecimento da realidade tematizada.

Os textos dos mais diversos gêneros e funções de que trata Chiapini, são, na verdade, os tipos relativamente estáveis de enunciados a que Bakhtin denomina gêneros do discurso, caracterizados pelo seu conteúdo temático, pelo seu estilo (estrutura lingüística) e pela sua construção composicional (organização textual e relação entre locutor e interlocutor).

Bakhtin (1992 [1953]), divide os diferentes gêneros em: primários, que são aqueles que estão relacionados às situações de comunicação oral e imediata, como as conversas informais, e secundários, aqueles que envolvem a escrita e que estão, portanto, relacionados a situações mais complexas.

O autor considera a língua como um instrumento de mediação usado pelo ser humano para agir com a linguagem, por isso abstrair a língua de seu contexto 
de produção é desconsiderar sua natureza. Faz-se necessário, portanto, estudar a inter-relação entre os gêneros primários e secundários e a "correlação entre língua, ideologia e visões de mundo" (BAKHTIN, 1992 [1953], p.282).

As palavras do autor comprovam a importância que Bakhtin dá aos gêneros de discurso e à necessidade de seu aprendizado.

Outros autores seguem o pensamento bakhtiniano quanto à necessidade do estudo dos gêneros discursivos, apesar disso, alguns defendem a utilização da expressão "gêneros de texto" ou "gêneros textuais" como sinônimos de gênero do discurso.

Observamos portanto, que a primeira questão que se levanta é com relação a terminologia utilizada pelos diversos autores e estudiosos do assunto.

Schneuwly \& Dolz (2004, p. 74), por exemplo, utilizam a expressão gênero textuais, partem da hipótese que "é através dos gêneros que as práticas de linguagem materializam-se nas atividades dos aprendizes" e consideram que:

Os gêneros textuais, por seu caráter genérico, são um termo de referência intermediário para a aprendizagem. Do ponto de vista do uso e da aprendizagem, o gênero pode, assim, ser considerado um megainstrumento que fornece um suporte para a atividade nas situações de comunicação, e uma referência para os aprendizes. (p. 75)

Bronckart (2003, p.77) define texto como:

uma unidade concreta de produção de linguagem, que pertence necessariamente a um gênero, composta por vários tipos de discurso, e que também apresenta os traços das decisões tomadas pelo produtor individual em função da sua situação de comunicação particular.

e opta pela expressão gênero de texto. Quando discute a noção de gênero de texto, comenta que:

[...] a partir de Bakhtin, essa noção tem sido progressivamente aplicada ao conjunto das produções verbais organizadas: às formas escritas usuais (artigo científico, resumo, notícia, publicidade, etc.) e ao conjunto das formas textuais orais, ou normatizadas, ou pertencentes à 'linguagem ordinária' (exposição, relato de acontecimentos vividos, conversação, etc). Disso resulta que qualquer espécie de texto pode atualmente ser designada em termos de gênero e que, portanto, todo 
exemplar de texto observável pode ser considerado como pertencente a um determinado gênero. (p.73).

O autor apresenta, ainda na mesma página, a dificuldade de classificação dos gêneros e menciona que apesar do acima exposto "[...] os gêneros de textos continuam sendo entidades profundamente vagas; as múltiplas classificações existentes são divergentes e parciais e nenhuma delas pode ser considerada como um modelo de referência estabilizado e coerente."

Optar-se-á, no presente trabalho, pela denominação gêneros discursivos, em vez de gêneros textuais ou gênero de texto, cunhadas pelos autores acima mencionados.

Independentemente da denominação dada, "o gênero é tratado por eles como uma forma de articulação das práticas de linguagem" (CRISTÓVÃO, 2001, p.23), por isso torna-se fundamental observar a necessidade do estudo dos gêneros discursivos na escola.

Faz-se necessário e urgente, portanto, um estudo para se selecionar, analisar e interpretar os diferentes tipos de gêneros discursivos constantes dos livros didáticos do primeiro ano do ensino médio, analisando como eles são explorados no livro didático o que é objeto e intenção do presente trabalho.

O corpus utilizado é formado por três livros para o primeiro ano do ensino médio, de três autores e de três editoras diferentes, a saber: Língua, literatura e produção de textos - José de Nicola - Editora Scipione - v.1, 2005; Língua e Literatura - Carlos Emílio Faraco e Francisco Marto Moura - Editora Ática - v. 1, 2005; Português: Linguagens: Literatura, Produção de textos e Gramática William Roberto Cereja e Thereza Cochar Magalhães - Atual Editora - v. 1, 2004.

A seleção do corpus deu-se da seguinte maneira: os livros Língua, Literatura e produção de Textos e Língua e Literatura foram selecionados porque são utilizados como suporte na escola em que leciona a autora da presente dissertação e o livro Português: Linguagens porque consta como analisado e aprovado no Catálogo do Programa Nacional do Livro do Ensino Médio PNLEM/2005. 
Serão selecionados textos e exercícios propostos nos livros didáticos acima mencionados e elaborada a análise e a avaliação do conteúdo de tais materiais. Para que essa análise e avaliação se concretizem, serão seguidas as seguintes etapas:

1) Pesquisa bibliográfica em livros, revistas especializadas e materiais disponíveis na Internet sobre algumas teorias existentes sobre gêneros. Além de Bakhtin e Bronckart, analisar-se-á a questão do gênero discursivo no livro didático na perspectiva da teórica brasileira Brandão, no capítulo 1.

2) No capítulo 2, apresentação de breve histórico sobre o livro didático no Brasil e seu papel em sala de aula e leitura do Manual do Professor em busca da presença do conceito de gênero discursivo e observar se este instrumento está cumprindo seu importante papel de apoio ao professor.

4) No capítulo 3, levantamento dos gêneros discursivos constantes dos livros didáticos selecionados no qual apresentaremos tabelas e gráficos dos resultados apurados.

5) No capítulo 4, análise da coerência entre a proposta do manual do professor, a proposta dos PCN e as atividades realizadas no corpus, o que, junto às outras etapas, dará a conhecer as respostas relativas às nossas perguntas de pesquisa.

6) E por fim, as considerações finais, as referências bibliográficas e o anexos. Como anexo, estamos considerando as páginas originais dos livros didáticos das quais retiramos as atividades para análise.

A presente dissertação destina-se ao professor que deve refletir e expandir os trabalhos com os gêneros discursivos no livro didático junto ao aluno do ensino médio. 


\section{GÊNEROS DISCURSIVOS: CLASSIFICAÇÕES E CONCEPÇÕES}

\subsection{Os gêneros discursivos em Bakhtin}

Bakhtin é um importante estudioso dos gêneros discursivos. O conceito de gênero discursivo já aparece em suas obras Marxismo e Filosofia da Linguagem e Problemas da Poética de Dostoiévski, do chamado "circulo de Bakhtin". A tradução do artigo "Os gêneros do discurso" é da década de cinqüenta, mas, no Brasil, teve-se acesso amplo a ela somente na década de noventa.

Em Estética da criação verbal (1992), quando trata da problemática e definição do gênero, o autor apresenta o termo gêneros do discurso da seguinte forma: "Qualquer enunciado considerado isoladamente é, claro, individual, mas cada esfera de utilização da língua elabora seus tipos relativamente estáveis de enunciados, sendo isso que denominamos gêneros do discurso." (op.cit., p.279). Para Bakhtin, gêneros do discurso são tipos relativamente estáveis de enunciados, mas bastante diversos, dadas as infinitas potencialidades das formas de discurso que a língua configura nos diversos campos sociais.

O autor menciona a heterogeneidade dos gêneros e os divide, como já dissemos anterioremente, em: primários, aqueles mais simples, como o diálogo cotidiano, a carta pessoal etc., e secundários, aqueles que aparecem em situação cultural mais complexa, por exemplo, o romance, o teatro, o discurso científico etc. Apesar das diferenças essenciais entre um e outro, afirma que "durante o processo de sua formação, esses gêneros secundários absorvem e transmutam os gêneros primários (simples) [...]" (op.cit., p.281)

Considera três aspectos constitutivos na produção dos gêneros: o tema, a forma composicional e o estilo. As dimensões dos gêneros discursivos de Bakhtin podem ser assim representadas: 


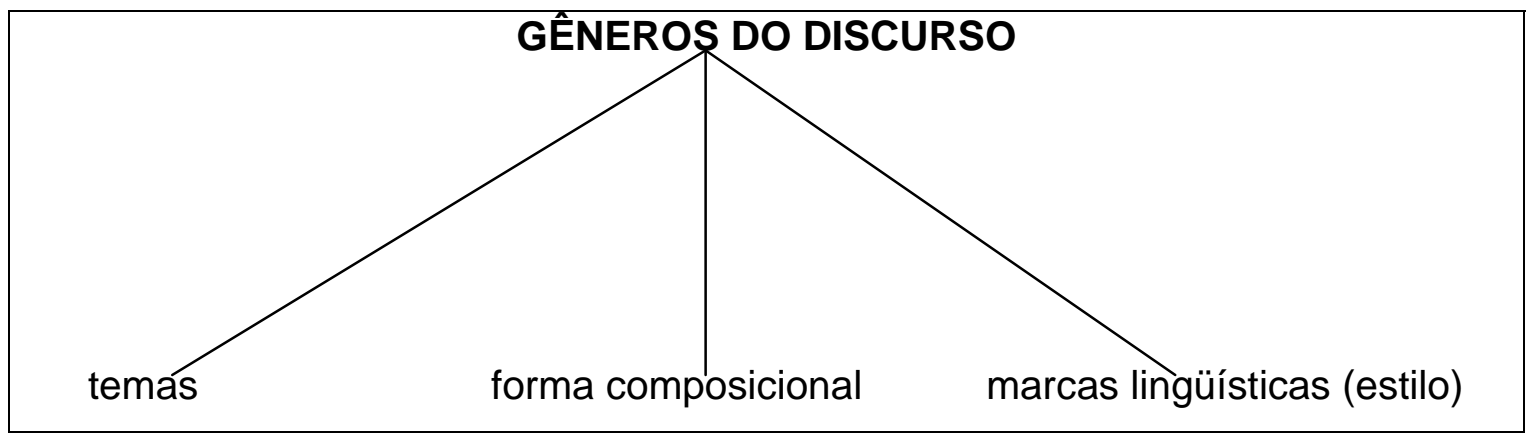

Fonte: ROJO, 2005, p. 196.

\section{Figura 1.1 Dimensões dos Gêneros do discurso}

Bakhtin define cada um desses aspectos da seguinte forma:

a) tema: é definido com a finalidade de provocar uma reação no leitor, para isso os sujeitos falantes que compõem o contexto compartilham informações de acordo com as esferas criativas a que estão vinculados. Tal processo é o objeto do tema, que ganha acabamento total garantindo compreensão e reação.

b) forma composicional: implica a estrutura e a organização do enunciado produzido por um falante. A forma composicional relaciona-se às estratégias lexicais, semânticas e pragmáticas, das quais o falante se apropria para que seu enunciado cumpra sua função comunicativa. Apesar disso, a forma composicional não é inventada cada vez que um falante se comunica através de um gênero do discurso; pois, segundo o autor, "um uso criativo livre não significa ainda a recriação de um gênero: para usá-los livremente, é preciso um bom domínio dos gêneros." (p.303). Os gêneros, na verdade, organizam nossa fala, mesmo que sua existência teórica seja desconhecida por nós. Para que um enunciado seja entendido precisamos saber escolher as articulações composicionais necessárias. c) estilo: pode ser geral, quando oferecido com formas padronizadas, por exemplo, uma ordem judicial, uma nota fiscal etc, que não dão lugar à característica ou estilo individual do produtor. Por outro lado, o estilo pode ser individual, uma vez que as palavras assumem determinado valor conforme o locutor que delas se apropria e contextualiza. Quando escolhemos uma palavra, partimos de intenções que direcionam o enunciado que será sempre expressivo. Conforme Bakhtin, o 
estilo também depende do modo como o locutor compreende e percebe seu destinatário, e do modo com que ele prevê sua atitude responsiva.

Nessa perspectiva, todos os falantes fazem uso dos gêneros discursivos, pois todos os enunciados possuem uma forma padrão e relativamente estável de estruturação. O autor acrescenta ainda que todo falante possui um rico repertório dos gêneros discursivos orais e escritos.

Enunciado para Bakhtin "é a unidade real da comunicação verbal. A fala só existe, na realidade, na forma concreta dos enunciados de um indivíduo[...]" (op.cit.,p.293)., por isso o autor salienta que:

O gênero do discurso não é uma forma de língua, mas uma forma do enunciado que, como tal, recebe do gênero uma expressividade determinada, típica, própria do gênero dado. No gênero, a palavra comporta certa expressão típica. Os gêneros correspondem a circunstâncias e a temas típicos da comunicação verbal e, por conseguinte, a certos pontos de contato típicos entre as significações da palavra e a realidade concreta." (op. cit, p.312)

Assim, o locutor escolhe suas palavras, suas orações, o que determina o estilo de seus enunciados, por outro lado o destinatário não pode ser ignorado, pois é dessa consideração que resulta o processo de escolhas do locutor. Bakhtin (1992 [1953]) conclui que é a partir da influência do destinatário que o locutor seleciona os recursos lingüísticos dos quais necessita.

Além dos recursos lingüísticos, a relação entre locutor e destinatário é determinada e estruturada de acordo com o que Bakhtin designa por esferas comunicativas, que são os lugares sociais nas diferentes instituições e situações sociais de produção de discursos. Tais esferas comunicativas podem ser divididas em: esferas do cotidiano: familiares, íntimas, comunitárias etc e esferas dos sistemas ideológicos constituídos: moral social, científicas, artísticas, religiosas, políticas, escolares e da imprensa.

Em um ato de comunicação, faz-se necessário adequar o gênero discursivo àquela situação de comunicação, por isso deve-se reconhecer, identificar e usar o gênero mais indicado. A comunicação verbal - escrita ou oral - será mais facilmente possibilitada se, logo no início da troca, for possível distinguir-se o gênero utilizado, seu tema e sua estrutura composicional. Para Bakhtin (1992 [1953], p. 302): 
Se não existissem os gêneros de discurso e se não os dominássemos, se tivéssemos de criá-los pela primeira vez no processo da fala, se tivéssemos de construir cada um de nossos enunciados, a comunicação verbal seria quase impossível.

As concepções contemporâneas de gênero discursivo (Bakhtin) ou gênero textual - termo bastante usado atualmente por alguns teóricos, como Bronckart -, evidenciam principalmente a dimensão social da linguagem. A linguagem verbal é uma atividade de interação social, compreendendo, portanto, a noção de audiência: quem escreve ou fala tem sempre em mente a idéia de um interlocutor, esteja ele presente ou não.

Apesar de a atenção do círculo bakhtiniano não ter recaído sobre o ensinoaprendizagem, seus estudos têm impulsionado muito as discussões teóricas, assim como, desenvolvimento pedagógico na área do ensino dos gêneros.

\title{
1.2 Os gêneros discursivos em Bronckart
}

Bronckart aparece nas referências bibliográficas de diversos pesquisadores que trabalham com o uso da linguagem escrita em sala de aula. Ele parte da teoria bakhtiniana e faz uma abordagem conceitual sobre o gênero de texto.

O autor abandonou a noção de "tipo de texto", que utilizava anteriormente, preferindo gêneros de texto e tipo de discurso. De acordo com seu pensamento, os gêneros podem ser identificados pelos tipos de discurso que os compõem. Observa-se que Bronckart usa o termo gênero de texto como sinônimo dos gêneros do discurso de Bakhtin.

Segundo Bronckart (2003, p.137):

\begin{abstract}
os textos são produtos da atividade de linguagem em funcionamento permanente nas formações sociais; em função de seus objetivos, interesses e questões específicas, essas formações elaboram diferentes espécies de textos, que apresentam características relativamente estáveis (justificando-se que sejam chamadas de gêneros de texto) (grifo do autor).
\end{abstract}

O autor considera gêneros de texto: o artigo científico, o romance, o editorial, a receita etc., e tipos de discurso: o discurso interativo, o discurso teórico, o relato interativo, a narração etc. Para melhor compreender esse posicionamento do autor é preciso saber que ele considera a linguagem uma operação ativa 
estruturada e representada por signos lingüísticos, por isso, possui uma característica individual que tem como finalidade a comunicação.

O autor vê dificuldade para o estabelecimento de um critério de classificação dos gêneros e, conseqüentemente, ele faz uma análise dos tipos de discurso atrelados às marcas lingüísticas em que observa as ações de linguagem num determinado contexto de produção.

A linguagem é uma atividade que precisa se organizar e se cristalizar sob a forma de discursos ou de textos, diversificando-se nos gêneros em função da necessidade individual de cada ser. Bronckart, assim como Bakhtin, valoriza a importância do meio social nas ações de linguagem dos agentes.

O uso de uma variedade de gêneros em situações imediatas de produção exige o domínio de diferentes gêneros. O autor reconhece que qualquer texto pode ser considerado como gênero e que os critérios que o designam são vários como a atividade humana, o efeito comunicativo desejado, o suporte, o tamanho, o tema abordado. Sustenta ainda que os gêneros desaparecem e aparecem. Desaparecem como ocorreu com a narração épica e aparecem como é o caso do editorial eletrônico.

Bronckart concebe os discursos primários como formas discursivas que se manifestam em situações de produção que exigem uma estrutura verbal e discute a terminologia bakhtiniana, definindo-a como flutuante e quanto ao gênero propõe que os gêneros do discurso de Bakhtin podem ser chamados de gêneros de textos e que os enunciados podem ser chamados de textos.

O mesmo autor ressalta que nenhum agente domina todos os gêneros, que cada indivíduo é exposto a um certo número de gêneros, os quais aprende a reconhecer, compreender e experimentar.

Reside aí, portanto, uma excelente justificativa para o trabalho com o maior número possível de gêneros discursivos na escola, para que o aluno possa reconhecê-los, compreendê-los e usá-los , quando necessário.

Além de discutir as noções de gêneros de texto e tipo de discurso, Bronckart (2003) aborda também os cinco tipos básicos de seqüências, que são: a seqüência narrativa, a seqüência descritiva, a seqüência argumentativa, a 
seqüência explicativa e a seqüência dialogal. $O$ autor afirma que as diferentes seqüências podem ser combinadas em um texto e que é da diversidade das seqüências e das modalidades de articulação que resulta a heterogeneidade composicional de grande número dos textos.

A noção de seqüência foi sugerida por Adam em artigo publicado em 1987 e aprofundada em vários outros artigos e livros do mesmo autor. Aproveitando a teoria bakhitiana, Adam (1992) propõe que por se tratarem de tipos nucleares, menos heterogêneos, os gêneros primários podem ser concebidos como seqüências textuais. O autor entende gêneros como componentes de interação social e seqüências como esquemas em interação dentro de um gênero. Em 1987 Adam concebeu as seqüências: narrativa, descritiva, argumentativa, expositivoexplicativa, injuntivo-instrucional, conversacional e poético-autotélica. Em 1992 reduziu o número das seqüências para cinco, que são: narrativa, descritiva, explicativa, argumentativa e dialogal.

Bronckart aproveita essa segunda proposta de Adam e, sucintamente, podemos descrevê-las da seguinte forma:

a) Seqüência narrativa: é sustentada por um processo de intriga, envolve personagens e consiste em uma história completa, com início, meio e fim.

b) Seqüência descritiva: é composta de fases organizadas em uma ordem não linear, mas hierárquica ou vertical.

c) Seqüência argumentativa: é uma sucessão de quatro fases, as premissas, a apresentação de argumentos, a apresentação de contra-argumentos e a conclusão.

d) Seqüência explicativa: origina-se na constatação de um fenômeno incontestável.

e) Seqüência dialogal: concretiza-se somente nos segmentos de discursos interativos dialogados.

O autor admite ainda um outro tipo de seqüência que ele passa a chamar de seqüência injuntiva. Segundo Bronckart, tais seqüências contribuem para a organização da infra-estrutura textual. 
Apresentamos abaixo um quadro de seqüências, representações dos efeitos e fases correspondentes, sugerido por Machado (2005, p.246-247)

\begin{tabular}{|c|c|c|}
\hline SEQUÊNCIAS & REPRESENTAÇÕES DOS EFEITOS PRETENDIDOS & FASES \\
\hline Descritiva & $\begin{array}{l}\text { Fazer o destinatário ver em pormenor elementos de } \\
\text { objeto de discurso, conforme a orientação dada a seu } \\
\text { olhar pelo produtor }\end{array}$ & $\begin{array}{l}\text { Ancoragem } \\
\text { Aspectualização } \\
\text { Relacionamento } \\
\text { Reformulação }\end{array}$ \\
\hline Explicativa & $\begin{array}{l}\text { Fazer o destinatário compreender um objeto de } \\
\text { discurso, visto pelo produtor como incontestável, mas } \\
\text { também como de difícil compreensão para o } \\
\text { destinatário. }\end{array}$ & $\begin{array}{l}\text { Constatação } \\
\text { Problematização } \\
\text { Resolução } \\
\text { Conclusão/avaliação }\end{array}$ \\
\hline Argumentativa & $\begin{array}{l}\text { Convencer o destinatário da validade de } \\
\text { posicionamento do produtor diante de um objeto de } \\
\text { discurso visto como contestável (pelo produtor e/ou } \\
\text { pelo destinatário) }\end{array}$ & $\begin{array}{l}\text { Estabelecimento de: } \\
\text { - premissas } \\
\text { - suporte argumentativo } \\
\text { - contra-argumentativo } \\
\text { - conclusão }\end{array}$ \\
\hline Narrativa & $\begin{array}{l}\text { Manter a atenção do destinatário, por meio da } \\
\text { construção de suspense, criado pelo estabelecimento } \\
\text { de uma tensão e subseqüente resolcução. }\end{array}$ & $\begin{array}{l}\text { Apresentação de: } \\
\text { - situação inicial } \\
\text { - complicação } \\
\text { - ações desencadeadas } \\
\text { - resolução } \\
\text { - situação final }\end{array}$ \\
\hline Injuntiva & $\begin{array}{l}\text { Fazer o destinatário agir de certo modo ou em } \\
\text { determinada direção. }\end{array}$ & $\begin{array}{l}\text { Enumeração de ações } \\
\text { temporalmente subseqüentes. }\end{array}$ \\
\hline Dialogal & Fazer o destinatário manter-se na interação proposta. & $\begin{array}{l}\text { Abertura } \\
\text { Operações transacionais } \\
\text { Fechamento }\end{array}$ \\
\hline
\end{tabular}

\section{Quadro 1.1 Representação das seqüências}

A partir do quadro 1.1, é possível observar que a identificação dos tipos de seqüência não é suficiente para um projeto de identificação-definiçãoclassificação dos textos. Por outro lado, não se pode afirmar que as seqüências não tenham utilidade, pois elas podem contribuir para a caracterização de determinado gênero.

Segundo Bonini (2005, p. 218): 
A diferença fundamental da seqüência em relação ao gênero [...] é sua menor variabilidade. Os gêneros marcam situações sociais específicas, sendo essencialmente heterogêneos. Já as seqüências, como componentes que atravessam todos os gêneros, são relativamente estáveis, logo, mais facilmente delimitáveis [...]

Por serem menos variáveis que os gêneros, as seqüências apresentam maior facilidade de delimitação. Sua contribuição está em caracterizar os diferentes gêneros, pois são componentes que atravessam todos os gêneros.

\subsection{Os gêneros discursivos na perspectiva de Brandão}

A discussão sobre as diversas classificações de tipos e gêneros permeiam os estudos da autora Brandão que apresenta uma vasta classificação dos diferentes tipos textuais e gêneros do discurso.

Brandão (2000) apresenta em uma primeira parte dos estudos, as diversas classificações/tipologias existentes. Ela comenta que "tem-se usado às vezes indistintamente os termos: gêneros, tipos, modos, modalidade de organização textual, espécies de texto e de discursos"(p.19). Reconhece que toda tipologia apresenta problemas, ora porque é restrita demais ora porque é ampla demais, problemas justificados pela heterogeneidade e complexidade do próprio texto.

A autora apresenta e discute as tipologias funcionais (de Bühler e Jakobson), as tipologias enunciativas (de Benveniste), as tipologias cognitivas (de Adam), a tipologia discursivo-interacionista (de Bakhtin) e a tipologia baseada no contínuo fala-escrita (de Marcuschi).

Os estudos da autora vão além das diversas tipologias. Na parte II do artigo já mencionado, os estudos adentram o processo ensino-aprendizagem, campo que mais interessa ao presente trabalho. Brandão (2002, p.5) afirma que "as noções de gênero do discurso e tipos textuais constituem ferramentas importantes no processo ensino/aprendizagem."

A autora cita Schneuwly e Dolz (2004, p.51) quando os autores afirmam que:

O trabalho escolar [...] faz-se sobre os gêneros, quer se queira ou não. Eles constituem o instrumento de mediação de toda estratégia de ensino e o material de trabalho, necessário e inesgotável, para o ensino da textualidade. A análise de suas características fornece uma primeira 
base de modelização instrumental para organizar as atividades de ensino que esses objetos de aprendizagem requerem.

Isso nos parece demonstrar a importância que Brandão vê na circulação dos gêneros discursivos na escola e corrobora a necessidade de discutirmos e abordarmos a presença e perfeita exploração desses gêneros no livro didático do primeiro ano do ensino médio.

Na página 6 do referido artigo, Brandão (2002) acrescenta que:

Cabe a escola cuidar para que os educandos ampliem ao longo dos anos de escolaridade seu contato e sua capacidade de manejar toda a gama heterogênea dos gêneros do discurso (orais e escritos) incluindo desde réplicas do diálogo cotidiano [...], o relato familiar, a carta [...], o repertório bastante diversificado dos documentos oficiais, as variadas formas de narrativas [...], o universo das declarações públicas [...] até as variadas formas de exposição científica e todos os modos literários.

A partir da seleção da tipologia gêneros do discurso e da forma de divisão dos gêneros (primários e secundários), podemos perceber que a autora opta pelo pressuposto bakhtiniano, o que será também a nossa opção na presente dissertação.

Brandão encerra o artigo afirmando que o contato e a capacidade de manejar os gêneros do discurso proporciona

ao educando todas as possibilidades para que ele se aproprie dos diferentes gêneros do discurso que circulam socialmente e saiba moverse no espaço intervalar, entre o sistemático e o não-sistemático, entre o canônico e não-canônico,entre o novo e o dado que caracteriza a dinâmica do gênero e que é próprio do plano discursivo, o exercício da linguagem será o lugar da sua autonomização e da sua constituição como sujeito. (idem, p.6)

Em seu estudo "Gêneros do discurso e tipos textuais"4, quando trata do equívoco que algumas abordagens pedagógicas cometem, Brandão menciona a contribuição do professor na adequada apropriação do educando quanto aos gêneros do discurso e comenta que: "O professor não pode perder de vista a

\footnotetext{
${ }^{4}$ Versão adaptada do texto publicado em BRANDÃO, H.H.N. (coord.) Gêneros do discurso na escola:mito, conto, cordel, discurso político, divulgação científica. São Paulo: Cortez,v.5, 2000 (coleção Aprender e Ensinar com Textos). Fornecido pela autora nas aulas da disciplina Análise do Discurso: enunciação, polifonia e construção do sentido, ministrada no segundo semestre de 2004, na USP-SP.
} 
dimensão histórico-cultural que a noção de gênero implica em decorrência do caráter dialógico e social da linguagem." (p.17)

Não restam dúvidas de que o aluno do ensino médio precisa vivenciar os diversos gêneros discursivos sugeridos por Bakhtin e aprender a construí-los adequadamente. Isso não só contribuirá para a vida acadêmica do aluno, mas, principalmente, para o seu convívio social, sua manutenção, sua independência e para o seu crescimento como indivíduo.

\subsection{Outras formas de classificação do gênero}

Meurer (2002) classifica os gêneros como gêneros textuais e apresenta sua importância para o crescimento do indivíduo; pois, segundo ele, é através dos textos que os alunos produzem, reproduzem ou desafiam a realidade social na qual vivem e dentro da qual vão construindo suas próprias narrativas pessoais.

Schneuwly e Dolz (2004) afirmam que por meio dos gêneros as práticas de linguagem encarnam-se nas atividades dos aprendizes e consideram ainda que:

Os gêneros constituem um ponto de comparação que situa as práticas de linguagem. Eles abrem uma porta de entrada, para estas últimas, que evita que delas se tenha uma imagem fragmentária no momento da sua apropriação. (p.74)

Shneuwly e Dolz (2004, p.121) separaram e classificaram os gêneros discursivos da seguinte forma: 


\begin{tabular}{|c|c|c|}
\hline $\begin{array}{l}\text { DOMÍNIOS SOCIAIS DE } \\
\text { COMUNICAÇÃO }\end{array}$ & $\begin{array}{l}\text { CAPACIDADES DE } \\
\text { LINGUAGEM } \\
\text { DOMINANTES }\end{array}$ & $\begin{array}{l}\text { EXEMPLOS DE GÊNEROS } \\
\text { ORAIS E ESCRITOS }\end{array}$ \\
\hline Cultura literária ficcional & $\begin{array}{l}\text { NARRAR } \\
\text { Mimeses da ação através da } \\
\text { criação de intriga }\end{array}$ & $\begin{array}{l}\text { Conto maravilhoso } \\
\text { Fábula } \\
\text { Lenda } \\
\text { Narrativa de aventura } \\
\text { Narrativa de ficção científica } \\
\text { Narrativa de enigma } \\
\text { Novela fantástica } \\
\text { Conto parodiano }\end{array}$ \\
\hline $\begin{array}{l}\text { Documentação e } \\
\text { memorização de ações } \\
\text { humanas }\end{array}$ & $\begin{array}{l}\text { RELATAR } \\
\text { Representação pelo } \\
\text { discurso de experiências } \\
\text { vividas, situadas no tempo }\end{array}$ & $\begin{array}{l}\text { Relato de experiência vivida } \\
\text { Relato de viagem } \\
\text { Testemunho } \\
\text { Curriculum vitae } \\
\text { Notícia } \\
\text { Reportagem } \\
\text { Crônica esportiva } \\
\text { Ensaio biográfico }\end{array}$ \\
\hline $\begin{array}{l}\text { Discussão de problemas } \\
\text { sociais contorversos }\end{array}$ & $\begin{array}{l}\text { ARGUMENTAR } \\
\text { Sustentação, refutação e } \\
\text { negociação de tomadas de } \\
\text { posição }\end{array}$ & $\begin{array}{l}\text { Texto de opinião } \\
\text { Diálogo argumentativo } \\
\text { Carta ao leitor } \\
\text { Carta de reclamação } \\
\text { Deliberação informal } \\
\text { Debate regrado } \\
\text { Discurso de defesa (adv.) } \\
\text { Discurso de acuação (adv.) }\end{array}$ \\
\hline $\begin{array}{l}\text { Transmissão e construção } \\
\text { de saberes }\end{array}$ & $\begin{array}{l}\text { EXPOR } \\
\text { Apresentação textual de } \\
\text { diferentes formas de } \\
\text { saberes }\end{array}$ & $\begin{array}{l}\text { Seminário } \\
\text { Conferência } \\
\text { Artigo ou verbete de } \\
\text { enciclopédia } \\
\text { Entrevista de especialista } \\
\text { Tomada de notas } \\
\text { Resumo de textos }\end{array}$ \\
\hline
\end{tabular}




\begin{tabular}{|l|l|l|}
\hline & & $\begin{array}{l}\text { "expositivos" ou explicativos } \\
\text { Relatório científico } \\
\text { Relato de experiência } \\
\text { científica }\end{array}$ \\
\hline Instruções e prescrições & $\begin{array}{l}\text { DESCREVER AÇÕES } \\
\text { Regulação mútua de } \\
\text { comportamentos }\end{array}$ & $\begin{array}{l}\text { Instruções de montagem } \\
\text { Receita } \\
\text { Regulamento } \\
\text { Regras do jogo } \\
\text { Instruções de uso } \\
\text { Instruções }\end{array}$ \\
\hline
\end{tabular}

Quadro 1.2 Aspectos tipológicos dos gêneros discursivos

Marcuschi (2005) também discute as definições e funcionalidades dos gêneros textuais e observa que os tipos textuais resumem-se em meia dúzia e são conhecidos como: narração, argumentação, exposição, descrição e injunção. Já os gêneros textuais (como ele classifica os gêneros discursivos) são inúmeros e podem ser exemplificados como: carta comercial, telefonema, resenha, inquérito, conferência, bate-papo por computador, cardápio, lista de compras, romance etc.

O autor comenta que "a expressão 'tipo de texto', muito usada nos livros didáticos e no nosso dia-a-dia, é equivocadamente empregada e não designa tipo, mas sim um gênero de texto." (p.25). Complementa ainda que: "Gêneros textuais não são fruto de invenções individuais, mas formas socialmente maturadas em práticas comunicativas." (p.35).

Marcuschi também menciona a necessidade da adequação do gênero ao tempo ou lugar, pois violam-se as normas sociais relativas aos gêneros textuais quando, por exemplo, conta-se uma piada em lugar não adequado às piadas.

O autor considera importante o trabalho com os gêneros, pois o vê como uma "extraordinária oportunidade de se lidar com a língua em seus mais diversos usos autênticos no dia-a-dia." (p.35).

Quando da classificação e representação dos gêneros textuais na fala e na escrita, Marcuschi (2001, p.41) elabora o seguinte quadro: 


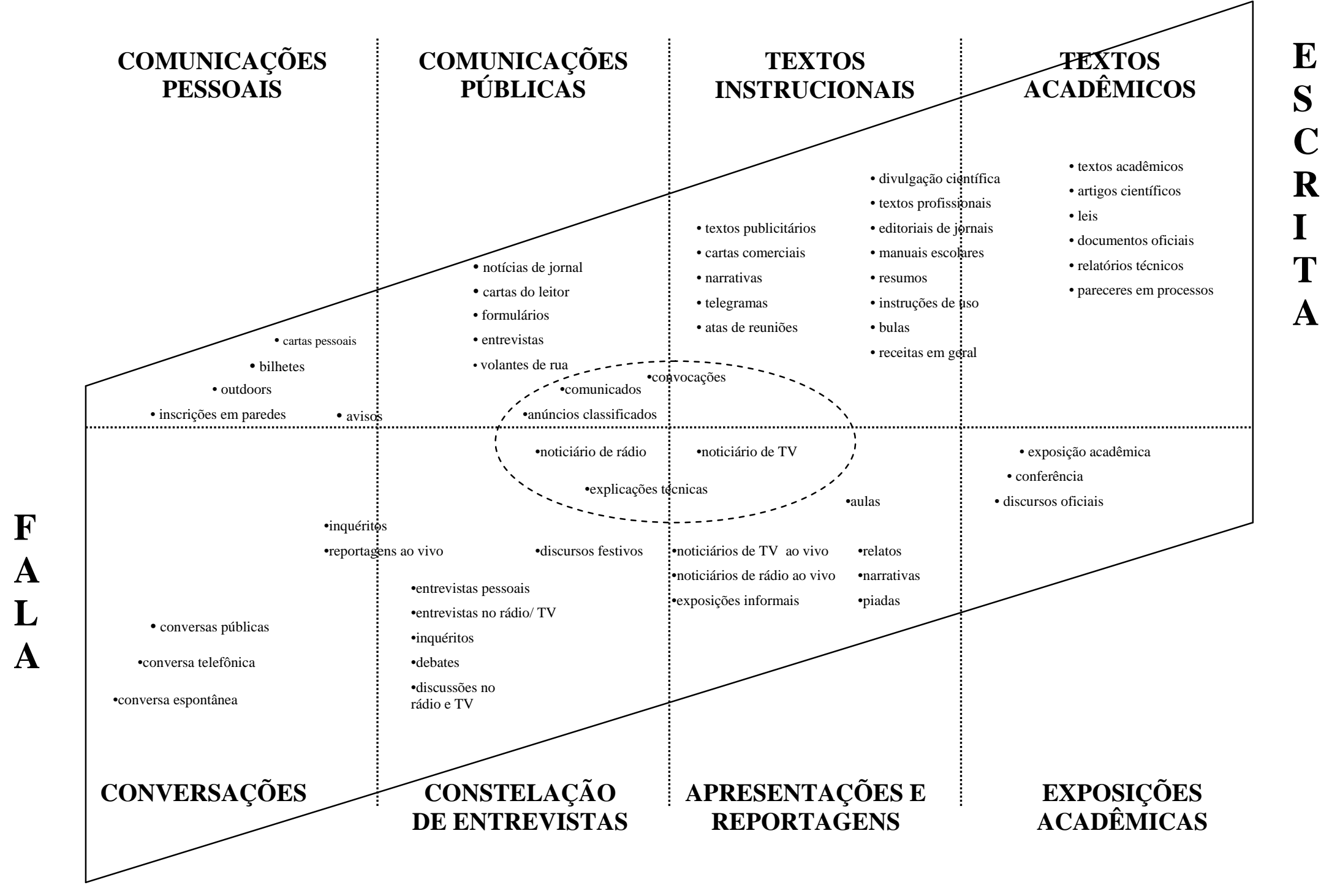

Quadro 1.3 Representação dos gêneros textuais 


\title{
1.5 Os gêneros discursivos nos PCN do Ensino Médio
}

Quando tratam das competências a serem desenvolvidas no aluno a partir da disciplina língua portuguesa, os PCN (1999) acrescentam que:

\begin{abstract}
O desenvolvimento da competência lingüística do aluno no Ensino Médio [...] não está pautado na exclusividade do domínio técnico de uso da língua legitimada pela norma padrão, mas, principalmente, no saber utilizar a língua, em situações subjetivas e/ou objetivas que exijam graus de distanciamento e reflexão sobre contextos e estatutos de interlocutores - a competência comunicativa vista pelo prisma da referência do valor social e simbólico da atividade lingüística e dos inúmeros discursos concorrentes. (p.131)
\end{abstract}

Isso já remete a um estudo da língua que vai além do saber ler e escrever corretamente e conduz às propostas dos estudos dos gêneros discursivos. Além de citar Bakhtin, os parâmetros fazem menção aos gêneros usando a tipologia gêneros discursivos:

O contexto, os interlocutores, gêneros discursivos, recursos utilizados pelos interlocutores para afirmar o dito/escrito, os significados sociais, a função social, os valores e o ponto de vista determinam formas de dizer/escrever. [...]. (p.143) (grifo nosso).

Em outro momento os gêneros são não só mencionados, mas valorizados como recursos para ampliação das possibilidades de usos da linguagem quando os autores dos PCN afirmam que: "o estudo dos gêneros discursivos e dos modos como se articulam proporciona uma visão ampla das possibilidades de usos da linguagem, incluindo-se aí o texto literário." (p.129)

Nas propostas de mudanças qualitativas para o processo de ensinoaprendizagem no nível médio, os PCN vêem a importância das diferentes manifestações da linguagem, que levam o aluno a apropriar-se do discurso e, além de compreender o discurso do outro, esse aluno pode divulgar suas idéias com objetividade e fluência.

Na página 144, descrevem-se alguns tipos de gêneros:

Os gêneros discursivos cada vez mais flexíveis no mundo moderno nos dizem sobre a natureza social da língua. Por exemplo, o texto literário se desdobra em inúmeras formas; o texto jornalístico e a propaganda manifestam variedades, inclusive visuais; os textos orais coloquiais e formais se aproximam da escrita: as variantes lingüísticas são marcadas pelo gênero, pela profissão, camada social, idade, região. 
Os PCN definem interação como uma atividade discursiva, ou seja, dizer alguma coisa a alguém, de uma determinada forma, num determinado contexto histórico em determinadas circunstâncias de interlocução. Segundo eles, o discurso se organiza a partir de finalidades e intenções do locutor e dos conhecimentos que o interlocutor possui sobre o assunto. A partir disso é que há a escolha de um gênero no qual o discurso se realizará, dos procedimentos de estruturação e de seleção de recursos lingüísticos.

Descrevem ainda o uso da língua, acrescentando que:

\begin{abstract}
depende de se ter conhecimento sobre o dito/escrito (a leitura/análise), a escolha de gêneros e tipos de discurso. Tais escolhas refletem conhecimento e domínio de 'contratos' textuais não declarados, mas que estão implícitos. Tais contratos exigem que se fale/escreva desta ou daquela forma, segundo este ou aquele modo/gênero. Disso saem as formas textuais. (p.144)
\end{abstract}

Observa-se que eles abordam de maneira superficial e não deixam claras as diferenças entre gênero e tipos textuais. Nos PCN, considera-se gênero a família de textos que têm características comuns, embora sejam intrinsecamente heterogêneas. Marcuschi (2005) afirma que os PCN não fazem uma "distinção sistemática" entre tipos (construtos teóricos/seqüências lingüísticas) e gêneros (enquanto textos empiricamente realizados e heterogêneos).

Vimos a necessidade de apresentar essas muitas classificações, divisões, tipologias e nomenclaturas para mostrar que não existe somente a complexidade dos próprios gêneros, mas que a primeira questão que se levanta é a dificuldade de se distinguir tipo e gênero discursivo/textual. Pareceu-nos que as muitas teorias existentes utilizam conceitos de tipo/gênero, gênero discursivo/gênero textual que ora se sobrepõem ora se diferenciam.

Muito ainda poderia ser apresentado acerca dessas discussões, mas o objetivo deste trabalho é verificar quais são e como os gêneros discursivos, na perspectiva bakhtiana, estão sendo explorados na escola, mais particularmente no livro didático dos alunos do ensino médio.

Indiscutível é a necessidade de se orientar o aluno na produção textual, fazendo-o entender as especificidades de cada gênero, tornando-o consciente do processo de leitura, interpretação e produção de um determinado gênero 
discursivo em determinada situação comunicativa. A reflexão centrada nos aspectos formais da língua, sem relação direta com os gêneros discursivos, não desenvolve a competência comunicativa do aluno, visto que ignora o caráter interlocutivo da linguagem.

O livro didático deve contribuir para o desenvolvimento da competência comunicativa do aluno, motivo pelo qual selecionamos no próximo capítulo alguns autores que discutem esse polêmico suporte, suas aplicações e seus usos na sala de aula. 


\section{O LIVRO DIDÁTICO: UMA BREVE REVISÃO}

Tarefa difícil é falar sobre o livro didático, pois todos sabemos que não se trata somente de mais um livro, mas sim de um instrumento político-pedagógico, ou seja, o livro-didático é decretado e controlado pelos governos, por isso deve ser elaborado a partir de critérios préestabelecidos por eles.

É preciso retomar sua origem, seu processo de evolução e toda a política educacional voltada a esse tão discutido instrumento, a fim de se observar seu valor como ferramenta de ensino-aprendizagem e, principalmente, se as medidas tomadas pelos governos brasileiros, no intuito de melhorar a qualidade do livro didático, têm surtido os efeitos esperados.

\subsection{Perspectivas histórica e política}

O livro didático remonta à Grécia Antiga e persiste na educação até os dias atuais. Desde os anos 300 a.C eles circulavam no Ocidente e passaram a ser manipulados com a finalidade de facilitar o ensino e a aprendizagem.

No Brasil, apesar de restrita bibliografia a respeito, sabe-se que é a partir dos anos 1920, com a fundação da Associação Brasileira de Educação, cuja iniciativa era a formação de uma política educacional, que ele começa a aparecer nas escolas. O material era utilizado em poucas escolas e era importado, dada a falta de condições brasileiras para a edição e produção de tais livros.

Os livros eram importados da França e de Portugal e chegavam aqui em seus idiomas de origem. Isso nos faz perceber que os alunos das nossas escolas pertenciam às classes sociais privilegiadas. Eles precisavam, necessariamente, dominar a língua francesa.

O livro didático só desponta mesmo no Brasil a partir de 1930, com os movimentos de nacionalização e expansão da rede de ensino. Segundo Holanda (1957, p.105), "[...] a queda da nossa moeda, conjugada com o encarecimento do livro estrangeiro, provocado pela crise econômica mundial, permitiu ao compêndio brasileiro - antes mais caro do que francês - competir comerciante com este." o 
ano de 1930 também marca o início de uma política educacional mais consciente e já com pretensões democráticas.

Em 1937, o Estado Novo cria o Instituto Nacional do livro - INL, órgão subordinado ao Ministério da Educação e Cultura. Apesar disso, a primeira definição de livro didático só acontece em 1938 com o Decreto-lei 1.006:

[...] Compêndios são livros que exponham total ou parcialmente a matéria das disciplinas constantes dos programas escolares; [...] tais livros também são chamados de livros de texto, livro-texto, compêndio escolar, livro escolar, livro de classe, manual, livro didático." (OLIVEIRA, 1980 apud FREITAG, COSTA e MOTTA, 1989, p. 13)

O mesmo decreto criou a CNLD (Comissão Nacional do Livro Didático) que tinha como funções examinar, julgar e indicar livros didáticos. Em 1939, o Decretolei 1.177 aumenta o número dos membros da CNLD, comissão que será questionada quanto à sua legitimidade em 1945 . O resultado de tal questionamento é que a comissão persiste.

Nos anos 60, assinam-se vários acordos entre o governo brasileiro e o governo americano, criou-se a COLTED (Comissão do Livro Técnico e do Livro Didático) e firma-se convênio entre o Ministério da Educação e Cultura, o Sindicato Nacional de Editores de Livros e a Agência Norte-Americana para o Desenvolvimento Internacional, com o intuito de se distribuir gratuitamente, no período de três anos, livros para os estudantes brasileiros.

A ajuda da Agência Norte-Americana para o Desenvolvimento Internacional foi criticada, pois alegava-se que a ajuda era antes uma forma de o americano controlar o nosso mercado livreiro, particularmente o mercado do livro didático brasileiro.

Em 1968, surge a FENAME (Fundação Nacional de Material Escolar), com as seguintes atribuições:

1. definir as diretrizes para a produção de material escolar e didático e assegurar sua distribuição em todo o território nacional;

2. formular programa editorial;

3. executar os programas do livro didático e

4. cooperar com instituições educacionais, científicas e culturais, públicas e privadas [...] (FREITAG, COSTA e MOTTA, 1989, p.15)

Segundo os mesmos autores, é em 1980 que aparece pela primeira vez "a vinculação da política governamental do livro didático com a criança carente" 
(1989, p.15) e são lançados o PLIDEF (Programa do Livro Didático - Ensino Fundamental), PLIDEM (Programa do Livro Didático - Ensino Médio) e PLIDESU (Programa do Livro Didático - Supletivo). A lei 7.091, de abril de 1983, apóia a Secretaria de Ensino de $1^{\circ}$. e $2^{\circ}$. graus - como eram chamados na época o Ensino fundamental II e o Ensino médio - e desenvolve programas de assistência aos estudantes desde a pré-escola até o $2^{\circ}$. grau.

Percebe-se, a partir do acima exposto, que "o livro didático não tem uma história própria no Brasil. Sua história não passa de uma seqüência de decretos, leis e medidas governamentais que se sucedem [...]" (FREITAG, COSTA E MOTTA, 1989, p.11).

Nos anos 90 os livros didáticos mereceram uma atenção especial do Ministério da Educação e Cultura que criou o PNLD (Programa Nacional do Livro Didático). Esse programa estabelece critérios para avaliação do livro didático, divulga a lista dos livros aprovados pelo MEC e distribui, nas escolas públicas, livros didáticos gratuitos das disciplinas Língua Portuguesa, Matemática, Ciências, História, Geografia.

Quanto aos critérios para a avaliação dos livros didáticos do ensino médio, segundo os autores do Catálogo do PNLEM/2005, os livros são avaliados por especialistas das áreas acima mencionadas e devem atender a três principais exigências comuns: ter correção das informações, conceitos e procedimentos que integram o componente curricular; ter adequação de sua proposta didáticopedagógica em relação à situação de ensino-aprendizagem e aos objetivos visados; e ainda ter sintonia com a legislação e os demais instrumentos oficiais que regulamentam e orientam a Educação Nacional (p.11).

Dois critérios comuns, se violados, são eliminatórios na análise e avaliação dos livros didáticos: 1) correção dos conceitos e das informações básicas e 2) respeito aos princípios de construção da cidadania (PNLEM, 2005). O livro será eliminado se formular erroneamente os conceitos que veicula; fornecer informações básicas erradas ou desatualizadas; mobilizar de forma inadequada esses conceitos e informações, levando o aluno a construir de forma incorreta conceitos e procedimentos e ainda, privilegiar determinado grupo,camada social 
ou religião do País; veicular preconceitos de origem, cor, condição econômicosocial, etnia, gênero, orientação sexual, linguagem ou qualquer outra forma de discriminação; divulgar matéria contrária à legislação vigente para a criança e o adolescente, no que diz respeito a fumo, a bebidas alcoólicas, a medicamentos, a drogas e a armamentos, entre outros; fazer publicidade de artigos, de serviços ou de organizações comerciais, salvaguardada a exploração didático-pedagógica do discurso publicitário; e, por fim, fazer doutrinação religiosa (p.10-11).

Enfim, o livro didático é recomendado ou eliminado, de acordo com critérios estabelecidos pelo estado, por meio do PNLEM, por isso Deusa Souza (1999,p.27) conclui que: "Faz-se necessário entender a escola enquanto um aparelho ideológico do estado e, no seu interior, o livro didático enquanto relação social de poder".

\subsection{O papel do livro didático}

O livro didático exerce relação de poder porque cria paradigmas norteadores de transmissão de conhecimento no contexto da sala de aula, mas é também vítima do poder do sistema que impõe ao autor do livro didático uma "ilusão de autoria", ou seja, "[...] o autor do livro didático nem sempre tem autonomia para configurar seu material [...]," comenta D. Souza (1999, p.31).

Segundo Queirós (2005): "O livro didático converge todo mundo para a mesma resposta." Apesar disso, o livro didático tem papel importante no processo de ensino-aprendizagem. Por outro lado, constitui-se num grande paradoxo dos nossos tempos: ora é a principal arma pedagógica ora é um recurso de defesa "[...] em relação a algo perigoso ou em situação que envolva ameaça ou competição." , conforme D. Souza (1999, p.93).

É considerado arma quando se constitui opressor, escravizador, ou seja, algo imposto tanto por seus autores, que propõem atividades que guiam a leitura e determinam o foco de atenção do aluno, como pelo sistema educacional que seleciona e impõe os livros didáticos a serem adotados pelas escolas.

O livro didático pode constituir-se em elemento de defesa quando bem manejado e explorado, isto é, o livro didático não deve sobrepor-se ao professor 
nem constituir-se verdade absoluta e inquestionável. Reside aí a importância da ação do professor que deve levar o aluno a um questionamento sobre o papel do livro didático e ao lugar ocupado pelo aluno na inevitável convivência com esse mesmo instrumento.

O livro didático deveria ser um dentre os muitos instrumentos de uma situação de aprendizagem, porém como concluíram Freitag, Costa e Motta (1989, p.124):

O livro didático não é visto como um instrumento de trabalho auxiliar na sala de aula, mas sim como a autoridade, a última instância, o critério absoluto de verdade, o padrão de excelência a ser adotado na aula.

O livro didático não pode ser o único instrumento a ser usado pelo professor e alunos em sala de aula nem tampouco ocupar o lugar de autoridade que estabelecem os parâmetros na relação do professor e dos alunos com o texto. Acreditamos que ele deva ser mais uma ferramenta a auxiliar o trabalho do professor e um facilitador das atividades dos alunos.

Embora reconheçamos ser esse o papel do livro didático, alguns professores o têm como único material de consulta, como constata Coracini (1999) pelo que é dito nas reuniões de professores do ensino fundamental e médio da escola pública do Estado de São Paulo.

Mesmo reconhecendo os defeitos dos livros didáticos, alguns professores o adotam como material exclusivo de trabalho por uma série de razões, dentre elas: pela necessidade de parâmetros para definir o que devem ensinar; pela necessidade de nortear o aluno quanto à referência para estudar; e, pior e infelizmente, por falta de tempo para preparar as suas aulas. Ou seja, transferem a sua responsabilidade da preparação das aulas, exclusivamente aos livros didáticos.

Antes de aceitarmos simplesmente as amarras políticas do passado que se arrastam até os nossos dias, temos que sugerir ao Ministério da Educação e Cultura e aos editores dos nossos livros didáticos que reflitam sobre tais políticas públicas e que abram espaço para novas opções de manuais com concepções de ensino-aprendizagem mais modernas; portanto, mais próximas da realidade de 
nossos alunos, como é o caso da adequada exposição e exploração dos gêneros do discurso.

\subsection{O Livro Didático de Português}

Apresentaremos a trajetória do livro didático de português, mas antes consideramos relevante comentarmos o ensino da língua portuguesa, particularmente, no ensino médio que é o objeto do presente trabalho.

Segundo determina a LDB, o ensino médio é etapa final da Educação Básica e tem como finalidade "desenvolver o educando, assegurar-lhe a formação comum indispensável para o exercício da cidadania e fornecer-lhe meios para progredir no trabalho e em estudos posteriores" (Lei 9394/96, apud PCN, 1999, p.43); além disso, deve vincular o aluno à prática social e ao mundo do trabalho. Observa-se que o aluno deve sair do ensino médio com uma formação geral: deve ter condições de pesquisar, buscar informações, analisando-as, ter capacidade de aprender, criar, argumentar e formular idéias coerentes.

No tocante ao ensino da Língua Portuguesa, deve ampliar o conhecimento já interiorizado no aluno e levá-lo a interpretar e produzir textos variados e assumir a palavra nas mais diversas situações com as quais se depare. Com isso, o aluno poderá exercer a cidadania e progredir nos estudos e no trabalho.

A linguagem deve fornecer ao educando tanto a transmissão de informações como a possibilidade de acesso à informação, à defesa de idéias e à partilha de conhecimentos.

Isso posto, observamos que os conhecimentos a serem dominados pelos alunos não podem ser os da gramática normativa, conhecimentos estes abstratos e compartimentados. Os alunos precisam dominar o funcionamento dos textos, os recursos de construção e reconstrução das tramas lingüísticas e produzir, a partir disso, os sentidos pretendidos.

A gramática sempre terá um papel importante no processo ensino/aprendizagem, porém sob outra perspectiva. Em vez de conceitos, deve levar os alunos ao domínio e aperfeiçoamento de suas práticas de leitura e 
produção. O processo deve levar os alunos a intuir a gramática, mas a partir de um privilegiado trabalho realizado em sala de aula.

O ensino da língua portuguesa deve fornecer ao aluno uma excelente convivência com os diversos textos e privilegiar os gêneros discursivos que aparecem com freqüência no meio social, profissional, acadêmico e pessoal do indivíduo.

Enfim, a pessoa deve expressar-se por meio da língua, manifestar seus pontos de vista e, por isso, a necessidade de a escola "possibilitar ao educando o reconhecimento dos valores veiculados pelos discursos de outrem, bem como pelos seus próprios, levando-o a assumir efetivamente seu papel de cidadão consciente, crítico e atuante" (GAVAZZI; EDUARDO, 2005, p.87)

\subsubsection{Origem e Evolução do livro didático de português}

Até a década de 50 estudava-se português nos manuais de gramática, ou seja, liam-se textos literários nas próprias antologias. O professor preparava o seu material de aula. Ninguém lhe impunha as atividades ou exercícios a serem trabalhados em sala de aula.

Nos anos 70 o perfil do professor mudou, pois não pertencendo mais às camadas sociais elevadas, eles não possuíam aquele conhecimento amplo dos professores de outrora. Surgiu, assim, a necessidade de adoção do livro didático. Segundo Geraldi (1993, p.94), o material didático para o professor "[...] facilitou a tarefa, diminuiu sua responsabilidade pela definição do conteúdo de ensino, preparou tudo - até as respostas no manual ou guia do professor".

A partir dessa data, os livros didáticos de português passaram a trazer textos jornalísticos, histórias em quadrinhos contendo mensagens a serem decodificadas pelo aluno. Os anos 80 intensificaram esse processo aumentando ainda mais a diversidade de textos apresentados no Livro Didático de Português.

A última década remete-nos a mudanças nos conteúdos, concepções teóricas e metodologias dos livros didáticos. Apesar de ainda relevarem a gramática da palavra e frase, o texto já começa a despontar, variando-se assim os autores e gêneros discursivos disponibilizados nos livros didáticos. 
De acordo com os PCN, lançados pelo MEC em 1997, a língua portuguesa tem como objetivo levar o aluno a:

[...] expandir o uso da linguagem em instâncias privadas e utilizá-la com eficácia em instâncias públicas, sabendo assumir a palavra e produzir textos - tanto orais como escritos - coerentes, coesos, adequados a seus destinatários, aos objetivos a que se propõem e aos assuntos tratados. (PCN, 1997, p.41).

Quando tratam das aulas de língua portuguesa, os PCN sugerem um trabalho que valorize a participação crítica do aluno com relação à língua materna e que mostre também as variedades e pluralidade de uso inerente a qualquer outra língua.

O Livro Didático de Português deve trazer uma diversificada variedade de gêneros discursivos, como carta, bilhete, história em quadrinhos, notícia, reportagem, classificado, biografia, entrevista, verbetes de dicionário, artigo de opinião, editorial, propaganda, peça teatral, crônica, bula, receita, fábula etc, contribuindo assim com as propostas dos PCN.

Porém a diversidade de gêneros não basta, além disso o Livro Didático de Português deve sugerir questões que levem o aluno a refletir e trabalhar os gêneros todos em quantidade equivalente . Segundo Marcuschi (2003, p.34):

\footnotetext{
Resta esperar que as próximas gerações de Livros Didáticos de Língua Portuguesa tenham mais sensibilidade para o fenômeno da língua oral e dediquem algo mais do que as parcas 3 páginas por obra e contemplem usos efetivos da língua oral que tão rica e viva vem sendo praticado por todos os seus usuários.
}

Acrescenta ainda Marcuschi que "a maioria dos LDP trabalham regras (no estudo gramatical); identificam informações textuais (nos exercícios de compreensão) e produzem textos escritos (na atividade de redação)" .(p.21) e isso não é suficiente para um adequado estudo e exploração dos gêneros discursivos.

Em seu estudo intitulado "As condições de produção/recepção dos gêneros discursivos em atividades de leitura de livros didáticos de língua portuguesa do ensino fundamental", Grillo e Cardoso concluíram que "falta muito a percorrer para que o livro didático disponível no mercado possa ser considerado instrumento de implementação dos currículos, cuja construção está claramente sugerida nos PCN de Língua Portuguesa." (2003, p. 122). 


\subsubsection{O livro didático de português segundo o Catálogo do Programa Nacional do Livro para o Ensino Médio - PNLEM/2005}

O PNLD é o resultado da necessidade de o Estado mostrar sua preocupação com o livro didático brasileiro. Em 1985, definiu-se o Decreto-Lei no. 91.542, importante marco para o ensino brasileiro. Tal decreto estabeleceu a adoção de livros reutilizáveis, a escolha de livros pelo conjunto de professores e a distribuição gratuita desses livros às escolas. Os dois quesitos que deveriam ser observados foram a questão da qualidade do livro e as condições políticas e operacionais.

Apesar de o decreto ser datado de 1985, somente no início da década de 90 o MEC passou a participar mais diretamente das discussões sobre a qualidade do livro didático. Em 1993, foi formada uma comissão de especialistas para avaliar a qualidade dos livros mais solicitados ao MEC naquela ocasião e estabelecer critérios para a avaliação de novas aquisições de livros didáticos.

O Estado iniciou essa avaliação com o livro didático do ensino fundamental e definiu que, além da qualidade editorial e gráfica, os livros deveriam ser analisados sob alguns outros critérios, como: a adequação didática e pedagógica e a pertinência do manual do professor para uma correta utilização do livro pelo professor. Estabeleceu também alguns critérios eliminatórios. Os livros analisados passariam a ser classificados a partir de quatro categorias: excluídos, nãorecomendados, recomendados com ressalva e recomendados. Em 1997, o programa divulgou os primeiros resultados do processo de avaliação por meio de um Guia de Livros Didáticos.

Seguiram-se a essa várias outras avaliações de livros didáticos do ensino fundamental e, com isso, constatou-se uma melhor qualidade dos livros e uma preocupação crescente das editoras com a adequação desses livros aos critérios estabelecidos. Surgiram novos títulos e nova geração de autores.

Segundo Batista (ROJO; BATISTA, 2003, p.101):

[...] com livros de melhor qualidade nas escolas, o PNLD vem contribuindo para um ensino de melhor qualidade: é uma referência consensual de qualidade para a produção de livros didáticos e para sua escolha, por professores: vem possibilitando uma reformulação dos 
padrões do manual escolar brasileiro e criando condições adequadas para a renovação das práticas de ensino nas escolas.

De acordo com a mesma autora, o PNLD fez mudanças significativas na avaliação dos livros didáticos; por outro lado, o MEC ainda deve atuar de forma mais efetiva na promoção de melhor qualidade do ensino, necessitando efetuar uma ampliação da concepção do livro didático, o que resultará numa oferta maior e mais rica de materiais inscritos.

Consideramos relevante mostrar o surgimento e o desenvolvimento do Progama Nacional do Livro Didático em razão de fazer parte do corpus do presente estudo um livro que foi avaliado e aprovado pelo Catálogo do Programa Nacional do Livro para o Ensino Médio . O sucesso alcançado pelo PNLD fez com que o MEC ampliasse sua ação de avaliação e de distribuição de livros didáticos para o ensino médio em 2005.

Na carta ao professor do Catálogo do PNLEM de 2005, o livro didático é apresentado da seguinte forma:

\begin{abstract}
Longe de ser a única possibilidade de trabalho, o livro didático é um instrumento que, utilizado como complemento do projeto políticopedagógico da escola, certamente contribuirá para promover a reflexão e a autonomia dos educandos, assegurando-lhes aprendizagem efetiva e contribuindo para fazer deles cidadãos participativos. (p.8)
\end{abstract}

Observa-se, novamente, que o livro deve servir de complemento, por isso não ser o único instrumento a ser utilizado em sala de aula, como acreditam e praticam alguns educadores.

A carta ainda acrescenta que o livro

[...] deve ser isento de erros conceituais ou preconceitos, deve incentivar o debate e estimular o trabalho do professor dentro e fora da sala de aula. É importante que sua proposta seja flexível, permitindo sua utilização em diversos contextos socioculturais e regionais. (p.8)

Na Apresentação do Catálogo, seus autores reforçam a informação de que o livro didático não será sob hipótese alguma um substituto do professor, mas sim um referencial para ampliação dos trabalhos no dia-a-dia escolar. Trata também da formação dos alunos do ensino médio que

deve levar em conta fatores diversos, como o respeito ao contexto social, à diversidade e à pluralidade; deve promover o desenvolvimento 
das capacidades de inferir, argumentar, pesquisar, produzir e deve estar em consonância com as múltiplas finalidades do ensino médio [...] (p.09)

Ainda na Apresentação, orienta-se que, para a disciplina Língua Portuguesa, deverá ser escolhido um único livro didático que será utilizado durante os três anos do ensino médio.

Há no Catálogo uma seção intitulada "Orientação para Escolha" e nela apresentam-se os múltiplos papéis do livro do ensino médio, que resumidamente consistem em favorecer a ampliação dos conhecimentos já adquiridos pelos alunos; oferecer informações que contribuam para a inserção dos alunos no mercado de trabalho e oferecer formação continuada ao professor.

Nessa seção, aconselha-se o professor a fazer uma escolha criteriosa posto que esse material será utilizado por três anos consecutivos. Sugere-se que o professor promova momentos de leitura e discussão dos resumos dos livros indicados, que procure relacionar os conteúdos dos livros à sua pedagogia, que procure observar a adequação dos conteúdos à proposta pedagógica da escola e ainda que observe se as atividades sugeridas estão relacionadas a outras áreas do conhecimento e experiência de seus alunos.

Percebe-se, portanto, que o Catálogo não foi criado somente para descrever o papel do livro didático, sua proposta é apresentar e relacionar os livros avaliados e aprovados e indicar aos professores alguns livros dentre os quais ele terá que escolher um para adoção.

A partir do acima exposto e confirmando o que já dissemos anteriormente, o livro didático é "imposto" pelos órgãos competentes, isto é, os professores só podem escolher seus livros didáticos com base em análises elaboradas por especialistas. Não têm liberdade de escolher livremente seu material de apoio. Nesse processo o professor é um mero espectador, senão um falso selecionador da sua ferramenta de trabalho. 


\subsection{0 gênero discursivo no Manual do Professor do livro didático do Ensino Médio}

\subsubsection{O Manual do Professor}

Há duas principais categorias de usuários ou consumidores do livro didático: o professor e o aluno. Por isso, as editoras lançam comumente o exemplar do aluno e o exemplar do professor. Além de trazer respostas às questões, o exemplar do professor, deveria fornecer, por meio do Manual do Professor, subsídios para um adequado trabalho dos conteúdos de cada capítulo.

O Manual do Professor deve cumprir este importante papel de trazer subsídios para o professor quanto ao trabalho adequado dos conteúdos do livro didático.

Os conceitos sobre os gêneros discursivos devem aparecer no Manual do Professor de todos os livros didáticos e tais conceitos precisam ser claros e coerentes.

O Manual do Professor é produzido pela editora e autores dos livros didáticos com o intuito de explicar sua proposta pedagógica e apresentar com clareza seus objetivos, a fim de orientar o professor quanto ao uso adequado da obra. Deve, portanto, além de trazer respostas às questões, estabelecer um diálogo com o professor de forma a orientá-lo em relação ao uso do livro e, principalmente, à exploração adequada dos conteúdos.

Segundo E. Marcuschi (2003, p.141), o Manual do Professor:

deve trazer respostas a um conjunto de questionamentos, como, por exemplo: Que fundamentos teórico-metodológicos embasam a proposta do LDP? Que noções de língua, texto, conhecimentos lingüísticos subjazem ao ensino-aprendizagem pretendido? Que enfoque avaliativo é privilegiado?

Quanto às respostas contidas no Manual do Professor, a mesma autora tece o seguinte comentário:

O MP estabelece que apenas uma determinada resposta é aceitável, rotula todas as demais como erradas e coloca nas mãos do professor o poder de decidir o que é verdadeiro e falso na interpretação do aluno. Nessa polarização certo-errado, ignora totalmente que a proposta do estudante deve ser sempre considerada e analisada, pois é indicadora 
do caminho por ele percorrido, do que ele contemplou e deixou de contemplar na apresentação de sua hipótese [...] (p.142)

Além da observação feita pela autora, o que percebemos no dia-a-dia da sala de aula é que o Manual do Professor, às vezes, traz respostas às quais percebemos que os alunos nunca conseguirão chegar.

A autora critica o fato de os manuais do professor não contemplarem a avaliação, pois não trazem uma seção específica sobre ela. Ao final do trabalho, Elizabeth Marcuschi (2003) conclui que o Manual do Professor tem que contribuir para a formação de professores autônomos, que saibam trabalhar com as diferenças e possam, portanto, oferecer aos alunos condições para o perfeito exercício da cidadania.

Quando trata da qualidade do livro do professor, o PNLEM/2005 menciona a necessidade de uma seção que explicite ao professor os objetivos e pressupostos teóricos relativos à elaboração daquele livro didático. Informa que o livro do professor não pode nem deve ser uma simples cópia do livro do aluno, contendo apenas as respostas aos exercícios.

Indica que para cumprir suas funções, o livro do professor deve:

- descrever a estrutura geral da obra, explicitando a articulação pretendida entre suas unidades e os objetivos específicos de cada uma delas;

- orientar, com formulações claras e precisas, os manejos pretendidos ou desejáveis do material em sala de aula;

- sugerir atividades complementares, como projetos, pesquisas, jogos, etc.;

- fornecer respostas ou padrões de respostas para parte das atividades propostas aos alunos;

- discutir o processo de avaliação da aprendizagem e mesmo sugerir instrumentos, técnicas e atividades;

- informar e orientar o professor a respeito de conhecimentos atualizados ou especializados, indispensáveis à adequada compreensão de aspectos específicos de uma determinada atividade ou mesmo da proposta pedagógica do livro. (p. 13)

A seguir será apresentada uma análise dos manuais das obras escolhidas para o presente trabalho, com a finalidade de se constatar ou não as verdadeiras funções do Manual do Professor, assim como verificar como e se os gêneros discursivos são tratados no exemplar do professor. 


\title{
2.4.2 O Manual do Professor do livro Língua e Literatura
}

Língua e Literatura é a $40^{a}$ edição, de 2002, da Editora Ática. Seus autores são Carlos Emílio Faraco, licenciado em Letras pela Universidade de São Paulo e Francisco Marto Moura, licenciado em Letras pela Universidade de São Paulo e professor de redação do Núcleo de Atendimento e Consultoria em Educação.

Na página 1 do livro aparece uma tarja amarela na qual está escrito em preto: "De acordo com as Diretrizes Curriculares Nacionais para o Ensino Médio." O exemplar do professor, do livro didático em questão, não contém um Manual do Professor. Traz uma seção Apresentação e as respostas às questões, em vermelho, nos próprios exercícios que aparecem ao longo dos capítulos. Então, realizaremos uma análise dessa Apresentação e de algumas respostas às atividades.

$\mathrm{Na}$ Apresentação, os autores comentam a agilidade das mudanças do mundo contemporâneo e a necessidade de o aluno estar preparado para elas. Abordam a divisão do livro em unidades que obedecem à seguinte estrutura: texto, estudo do texto, literatura, gramática, recursos de estilo, redação, em outras palavras, questões de vestibular e sugestão de atividades complementares.

Os autores não utilizam, especificamente, a expressão gêneros discursivos, mas propõem um trabalho com os gêneros, como se pode perceber em:

\begin{abstract}
Partindo do princípio de que o texto não é exclusividade da palavra, selecionamos para a coleção não só textos literários mas também anúncios publicitários, gráficos, fotos, quadros, esculturas, cartuns, artigos jornalísticos ou científicos, entre outros. Esse entrelaçamento de textos de natureza diversa permite trabalho constante de intertextualidade, além de variadas formas de leitura, visando permitir que o aluno possa articular diferentes linguagens e seus contextos. (p.3)
\end{abstract}

São apresentados aí alguns gêneros como: anúncios publicitários, cartuns, artigos jornalísticos e científicos, além da linguagem visual representada pelas fotos, quadros etc. Os autores sugerem um trabalho de intertextualidade e de variadas formas de leitura, que visam levar o aluno a articular diferentes linguagens. Tal trabalho remete ao estudo dos gêneros.

Quando explicam a última seção de cada unidade, acrescentam:

No final de cada unidade, sugerem-se várias atividades, como assistir a filmes, organizar debates ou mesas-redondas, ler outros livros, pesquisar informações em outras fontes, discutir programas de rádio e 
TV, elaborar jornais, revistas, já que o livro didático é um entre os muitos materiais disponíveis para se estudar a língua portuguesa. (p.3)

Aqui os autores misturam gêneros: filmes, debates e mesas-redondas, com suporte material: programas de rádio e TV, revistas e livro didático. E ainda classificam os gêneros somente como materiais disponíveis para o estudo da língua portuguesa e não como fontes que levariam o aluno a aprender a estruturar enunciados, como propõe Bakhtin.

Em relação às respostas das questões, no interior do livro, observa-se em diversos momentos que os autores dialogam com o professor, às vezes, simplesmente, para informá-lo, como: "Prof.: as palavras apresentadas são sugestões" (p.93); outras vezes, para orientá-lo quanto às providências necessárias para uma melhor compreensão dos alunos, por exemplo: "Prof.: solicitar que mais de um aluno faça o exercício e analisar com a classe qual deles se adequou melhor à leitura proposta." (p.26). Outro exemplo: "Prof.: aprofundar o exercício para conceituar amplamente ficção. Geralmente os alunos associam apenas a ficção científica." (p.53).

Aparecem, em alguns casos, propostas de trabalhos com os gêneros discursivos, os autores sugerem a adequada interpretação do texto e discutem a questão dos traços caracterizadores do nível sociocultural, como esta: "Prof.: depois de analisar com a classe algumas respostas, conversar com os alunos a respeito da pluralidade interpretativa de um texto, enfatizando os limites dessa pluralidade. Mostrar que há interpretações inaceitáveis, por ferirem a coerência do texto. Insistir, sobretudo, no fato de que nenhuma interpretação é possível fora do contexto." (p.14). Outro exemplo aparece na página 24: "Prof.: conversar com os alunos a respeito da linguagem como traço que caracteriza o nível sociocultural da narradora. Essa marca, além da espontaneidade do relato, seria provavelmente alterada por uma revisão do texto." E ainda: "Prof.: essa proposta visa a dar seqüência ao trabalho de sensibilização do aluno para o fato de uma língua não ser necessariamente melhor que a outra, mas apenas mais adequada em determinados contextos. (grifo nosso) 
A preocupação dos autores com relação à exposição oral restringe-se a sugerir, em diversos momentos, a leitura em voz alta, como é o exemplo da página 83: "Prof.: solicitar que vários alunos façam a leitura. A classe elege a mais adequada." Por outro lado, não mostram nenhuma distinção entre os gêneros discursivos de língua oral e gêneros de língua escrita. Aqui teriam uma excelente oportunidade de levar o aluno a um estudo da modalidade oral da língua portuguesa indicado pelos PCN, mas não o fizeram, sugeriram apenas um estudo da voz.

Constata-se aqui a afirmação de Schneuwly e Dolz (2004) de que apesar de a linguagem oral estar bastante presente nas salas de aula (nas rotinas cotidianas, na leitura de instruções, na correção de exercícios etc.) é comum ouvir-se dizer que ela não é ensinada, a não ser incidentalmente.

Corrobora, ainda o pensamento acima Gomes Júnior (2005, p.28):

Dessa forma, nas propostas de atividade em que essa concepção prevalece, percebe-se a ausência de orientações para um trabalho eficiente com a oralidade. Ao se fazerem ausentes tais orientações, suprimem-se meios para que o aluno conheça os distintos gêneros [...]

Os autores do livro Língua e Literatura não fazem menção à palavra gênero discursivo nem trazem conceitos teóricos concernentes a eles. Poemas e cartum são classificados somente como textos, como pode-se observar no exemplo abaixo. Eles trabalham com textos diversos, mas não esclarecem que se trata de gêneros discursivos.

Prof.: a diferença mais evidente nos três textos (o termo aqui está empregado em sentido amplo) está na conseqüência que a observação provoca. No primeiro caso, o eu-poético sente ciúme da imagem do eu no espelho; no segundo, o eu-poético busca a identidade perdida no intervalo entre ele e o espelho; no cartum, a observação provoca surpresa e desencadeia o pedido de socorro. Comentar com os alunos que o verso 'apesar do que me revela' no primeiro poema, tem relação com o Cartum de Quino.(...). (p.115)

Observa-se, em diversos diálogos com o interlocutor do Manual, que os autores pressupõem que o professor seja competente e preparado para tais abordagens. Isso mostra que as sugestões deixam a desejar quanto à sua função 
de orientar o professor no tocante à exploração adequada dos conteúdos estudados.

\subsubsection{O Manual do Professor do livro Língua, Literatura e Produção de Textos}

Língua, Literatura e Produção de Textos foi publicado pela Editora Scipione, em 2005, seu autor é José de Nicola, professor de cursos pré-vestibular e escolas particulares de ensino médio desde 1968 e também autor de várias obras dedicadas ao ensino da língua e produção de textos para o ensino fundamental e médio.

Esse livro traz, nas páginas finais, um denso manual, com 56 páginas, intitulado "Assessoria Pedagógica". Já no sumário, o autor apresenta a divisão do trabalho em 6 partes: 1) O ensino da língua, literatura e produção de textos e mudança de paradigma; 2) Formando o leitor e o produtor de texto: as estruturas gramaticais dos textos; 3) Formando o leitor e o produtor de texto: os textos do cotidiano; 4) Formando o leitor e o produtor de texto: os textos artísticos; 5) Respostas das atividades propostas e 6) Referências bibliográficas.

$\mathrm{Na}$ primeira parte do manual, o autor lança duas perguntas que todo educador deve julgar vitais: o que queremos que nosso aluno domine, que competências e habilidades queremos trabalhar? O que faremos e como faremos para que nosso aluno atinja este objetivo?

O próprio autor responde às questões afirmando que: "Acreditamos que, no caso específico das aulas de Português, todo professor se daria por feliz e realizado se seus alunos, ao concluírem o curso, fossem leitores/ouvintes atentos e competentes produtores de texto (tanto na modalidade oral como na escrita). (p.3)

Na terceira parte do Manual, o autor traz um subitem intitulado "Gêneros e tipos textuais". Nesse subitem, cita os autores Koch, Adam, Bakhtin, Marcuschi. Avalia as afirmações dos autores e comenta que, no presente livro, seguirá a classificação de Marcuschi e de Adam apesar de isolar as seqüências conversacionais, argumentando que "não a entendemos como um tipo textual e 
sim como uma modalidade: um texto conversacional sempre será uma sequência narrativa, ou injuntiva, ou explicativa [...]" (p.11)

Acrescenta ainda o manual que:

Embora esta coleção aborde com mais ênfase a leitura no conceito restrito de atribuição de sentidos de um texto escrito, em razão das limitações do gênero 'livro didático' e do espaço [...], é importante salientar que a leitura no sentido amplo, isto é a leitura de 'textos' em diversas modalidades, de diversos tipos e com diferentes linguagens é o objetivo geral.

Apesar de o título do subitem ser: "Os gêneros e tipos textuais", o autor usa muito pouco suas próprias palavras para explicar e esclarecer a proposta do livro quanto ao trabalho com os gêneros discursivos. Na página 11, quando comenta uma citação de Marcuschi, o autor menciona que

\begin{abstract}
é importante comentar que, assim como os gêneros textuais têm um formato convencionado que se reitera e pelo qual o identificamos, os tipos textuais têm seqüências com determinadas características gramaticais que se distinguem e identificam como tais. Ambas as noções são conhecimentos básicos para a construção de sentidos ora do produtor, ora do leitor de textos.
\end{abstract}

A Quinta parte do Manual é dedicada às respostas das atividades propostas no livro didático e observamos que o autor se dirige diversas vezes ao professor tecendo comentários, como: "Professor: O trecho não expressa um fato atual, que acontece no momento da enunciação, mas sim o tempo presente do indicativo com valor de imperativo, reforçado pelo emprego do vocativo"(p.18). Outras vezes apresenta teorias, como: "Professor: Comentar que o sujeito elíptico da primeira oração tem referência catafórica, isto é, o seu referente (os sagüis), marcado pela terceira pessoa do plural no infinitivo flexionado, aparece depois." (p.19)

Quanto ao trabalho com os gêneros e tipos textuais, o autor faz observações ao professor como: "Professor(a): Espera-se que os alunos percebam elementos como: gênero textual (artigo de jornal, notícia), suporte (jornal O Estado de S.Paulo, caderno LINK, destinado ao público que trabalha e gosta de informática e tecnologia, seção RÁPIDAS, notícias rápidas) [...]" (p.28)

Em diversas outras respostas a questões, o autor não usa o vocativo professor, mas utiliza a expressão: "Espera-se que o aluno". 
O Manual traz também diversas ocorrências de comentários das universidades quanto às respostas de alguns exercícios de vestibular. Aproveitamos a oportunidade para refletir sobre a efetiva validade da preocupação com os vestibulares, posto que o livro didático em questão é para alunos que ainda estão cursando o primeiro ano do ensino médio. Observa-se nele, assim como em diversos outros livros didáticos, uma grande preocupação com a preparação do aluno para os vestibulares em detrimento da utilização de um tempo maior com a formação desse mesmo aluno, por exemplo, explorando melhor os gêneros discursivos no livro didático.

\subsubsection{O Manual do Professor do livro Português Linguagens}

Português Linguagens: Literatura, Produção de Texto, Gramática é a $4^{a}$ edição, de 2004, da editora Atual Editora. Um de seus autores é William Roberto Cereja, professor graduado em Português e Lingüística e licenciado em Português pela Universidade de São Paulo, é mestre em teoria literária pela Universidade de São Paulo, é doutor em lingüística aplicada e análise do discurso pela PUC-SP e professor da rede particular de ensino em São Paulo. Tereza Cochar Magalhães é a outra autora do livro. Professora graduada em Português e Francês pela FFCL de Araraquara, é mestre em Estudos Literários pela Unesp de Araraquara e professora da rede pública de ensino em Araraquara. Ambos são autores de outros livros didáticos para o ensino fundamental e médio.

O Manual do Professor do livro didático em questão, contrariando o que é convencionalmente esperado, não traz respostas aos exercícios do livro e sim um diálogo com o professor dividido em 5 partes: introdução, metodologia, estrutura da obra, sugestões estratégicas e bibliografia. As respostas às questões aparecem em vermelho nos próprios exercícios no interior do livro.

$\mathrm{Na}$ introdução, os autores discorrem sobre a reformulação e atualização da obra dada a necessidade de se atender às propostas feitas pelos PCNEM. Comentam a divisão da obra em literatura, produção de textos e ensino da língua e já trazem menções aos gêneros textuais ou discursivos, citando, inclusive, 
alguns gêneros orais públicos, como: debate, seminário, entrevista e mesaredonda.

É na metodologia da Produção de Texto que os autores tratam e exploram a importância do trabalho com os diversos gêneros. Os autores comentam que dada a preocupação do professor em entender a proposta do trabalho com os gêneros, faz-se necessária a apresentação de fundamentos teóricos. Perguntam e respondem à questão: O que são gêneros à luz da teoria de Bakhtin. Discorrem sobre "O gênero como ferramenta", trazendo à tona as pesquisas de Schneuwly e Dolz e Bronckart .

O Manual menciona que

Os relatos de experiências de profissionais de ensino que se propuseram a ensinar produção textual a partir do enfoque de gêneros têm demonstrado que essa abordagem não só amplia, diversifica e enriquece a capacidade dos alunos de produzir textos orais e escritos, mas também aprimora sua capacidade de recepção, isto é, de leitura/audição, compreensão e interpretação dos textos. (p.7)

Ainda na metodologia, os autores tratam do gênero a serviço da construção do sujeito e da cidadania; da diversidade textual e aprendizagem em espiral; do agrupamento de gêneros e progressão curricular e dos gêneros como democratização do texto.

No decorrer de toda a explanação sobre os gêneros textuais ou discursivos, os autores citam, como exemplos de gêneros, os seguintes: relato pessoal, notícia, conferência, receita, e-mail, bilhete, carta, telegrama, cartas argumentativas de solicitação e de reclamação, carta do leitor, editorial, poema, crônica, conto, narrativas de ficção.

Cereja e Magalhães acrescentam que a partir do aprendizado dos gêneros discursivos, "o aluno toma consciência de que pode, como cidadão, manifestar seus pontos de vista, opinar e interferir nos acontecimentos do mundo concreto." (p.8)

O Manual traz propostas para o trabalho com os gêneros discursivos e trata do papel do professor que deve ser o de professor de produção de textos e não mais professor de redação. 
São apresentados também no Manual critérios para a avaliação da produção de textos, sugestão de trabalhos e projetos com os gêneros discursivos, o jornal em sala de aula e uma vasta bibliografia que deve servir como apoio e como referência bibliográfica ao professor.

A partir dessa breve análise dos três Manuais do Professor dos livros didáticos objeto de estudo do presente trabalho, observamos que o livro Língua e Literatura, apesar de informar que está de acordo com as Diretrizes Curriculares Nacionais para o Ensino Médio não faz, no Manual, menção aos gêneros discursivos, não apresenta os fundamentos terórico-metodológicos que embasam a proposta do livro e nem se propõe a um trabalho minucioso com os gêneros discursivos. Apesar disso, o livro traz uma boa diversidade desses gêneros.

Contrariamente ao acima exposto, o Manual do Professor do Língua, Literatura e Produção de Textos traz uma proposta mais próxima das exigências do PNLEM, pois o Manual apresenta uma parte dedicada aos gêneros e tipos textuais; comenta, mas não esclarece com muita propriedade, os fundamentos teóricos e autores que norteiam o trabalho com os gêneros discursivos nesse livro; distingue gênero e suporte e dialoga com o professor em muitas repostas às questões.

Já o Manual do Professor do livro Português Linguagens faz diversas menções aos gêneros textuais ou discursivos, cita e comenta Bakhtin e Shneuwly, apresenta e explica vários gêneros discursivos, traz sugestão de bibliografia sobre o assunto e propõe, inclusive, trabalhos e projetos com os gêneros discursivos.

Observamos, portanto, que os três manuais analisados, de maneira explícita ou implícita, apresentam uma preocupação de seus autores com um trabalho envolvendo os gêneros discursivos nos livros didáticos selecionados. Constatamos também que o Manual do Professor do livro Português Linguagens atende melhor às exigências do PNLEM, quanto ao trabalho com os gêneros discursivos.

Passaremos no próximo capítulo a um levantamento dos gêneros discursivos que circulam no corpus da presente dissertação. 


\section{A CIRCULAÇÃO DOS GÊNEROS DISCURSIVOS NOS LIVROS DIDÁTICOS SELECIONADOS}

Neste capítulo, pretendemos mostrar como os gêneros discursivos são distribuídos nos livros didáticos selecionados. Será apresentada uma análise quantitativa para que o leitor tenha uma idéia de quantos e quais gêneros discursivos circulam nos três livros. Demonstraremos, com o auxílio de tabelas, as seguintes ocorrências:

- Quais gêneros discursivos aparecem nos livros.

- O que representam em termos de percentual

- Entre os gêneros discursivos, quais os mais presentes em cada livro.

- Lugar que ocupam em cada unidade dos livros.

Com a finalidade de facilitar a visualização, as ocorrências serão apresentadas em tabelas e gráficos que resumem a distribuição dos gêneros discursivos de cada um dos livros didáticos, separadamente.

Os livros didáticos selecionados apresentam uma grande diversidade de gêneros discursivos, como: poemas, artigos de jornais e revistas, tiras de quadrinhos, músicas, anúncios, crônicas, cartas, relatos, convites etc.

Pela dificuldade de um trabalho que pudesse dar conta da descrição de todos os gêneros discursivos encontrados dentro dos livros didáticos selecionados, optou-se, neste primeiro momento, por restringir-se somente àqueles que aparecem representados por textos no decorrer dos capítulos. As imagens como: pinturas, caricaturas, desenhos, mapas e outras não serão contempladas neste trabalho nem no levantamento nem na análise dos gêneros discursivos existentes nos livros didáticos escolhidos.

\subsection{Língua e Literatura}

O livro possui 11 unidades e cada unidade tem a seguinte estrutura: texto, estudo do texto, literatura, gramática, recursos de estilo, redação, em outras palavras, questões de vestibulares e sugestões de atividades complementares. 
Os gêneros que aparecem na obra são muito diversos e estão distribuídos em todas as unidades. Apresentaremos, a seguir, a tabela $3.1 \mathrm{com}$ todos os gêneros discursivos e as ocorrências que aparecem por unidade.

Tabela 3.1 Gêneros discursivos no livro Língua e Literatura

\begin{tabular}{|c|c|c|c|c|c|c|c|c|c|c|c|c|c|}
\hline GÊNERO & \begin{tabular}{|c|} 
UNDADE \\
1
\end{tabular} & $\begin{array}{c}\text { UNDADE } \\
2\end{array}$ & $\begin{array}{c}\text { UNDADE } \\
\mathbf{3}\end{array}$ & $\begin{array}{c}\text { UNDADE } \\
4\end{array}$ & $\begin{array}{c}\text { UNDADE } \\
5\end{array}$ & $\begin{array}{c}\text { UNDADE } \\
6\end{array}$ & \begin{tabular}{|c|} 
UNDADE \\
7
\end{tabular} & $\begin{array}{c}\text { UNDADE } \\
8\end{array}$ & $\begin{array}{c}\text { UNDADE } \\
9\end{array}$ & $\begin{array}{c}\text { UNDADE } \\
10\end{array}$ & $\begin{array}{c}\text { UNDADE } \\
11\end{array}$ & TOTAL & $\%$ \\
\hline Poema & 3 & 1 & 6 & 3 & 14 & 5 & 3 & 8 & 4 & 7 & 14 & 68 & $33 \%$ \\
\hline Verbete & 1 & 1 & & 3 & 5 & 2 & 1 & 4 & & & & 17 & $8 \%$ \\
\hline Trecho romance & 1 & 1 & 2 & 2 & & 3 & 4 & 1 & & & 1 & 15 & $7 \%$ \\
\hline Notícia & 1 & 2 & 2 & 3 & 4 & & & & & & 2 & 14 & $7 \%$ \\
\hline Música & & 2 & 1 & 2 & 1 & 2 & & & 1 & 1 & & 10 & $5 \%$ \\
\hline Trecho livro & & 1 & & 1 & & 1 & 1 & 3 & 1 & 1 & 1 & 10 & $5 \%$ \\
\hline Anúncio & 2 & 1 & 2 & & 3 & & & & & & 1 & 9 & $4 \%$ \\
\hline Conto & 1 & & 4 & 1 & 2 & & & & & & & 8 & $4 \%$ \\
\hline Cartum & 2 & 1 & 1 & & & 2 & 1 & & & & & 7 & $3 \%$ \\
\hline Artigo & & 1 & 1 & & 1 & 2 & 1 & & & & & 6 & $3 \%$ \\
\hline Cantiga & & & & & & 6 & & & & & & 6 & $3 \%$ \\
\hline Título notícia & 4 & & 2 & & & & & & & & & 6 & $3 \%$ \\
\hline Peça teatral & & & & 2 & & & 3 & & & & & 5 & $2 \%$ \\
\hline Sermão & & & & & & & & & & 5 & & 5 & $2 \%$ \\
\hline Tira & 1 & 1 & & 2 & & & & & & 1 & & 5 & $2 \%$ \\
\hline Carta & & & & & 1 & & & & 2 & 1 & & 4 & $2 \%$ \\
\hline Diálogo & 1 & 2 & & & & & & & & & & 3 & $1 \%$ \\
\hline Logomarca & 2 & & & & & & & & & & & 2 & $1 \%$ \\
\hline Bate-papo & & & & & & 1 & & & & & & 1 & \multirow{8}{*}{$4 \%$} \\
\hline Crítica & & & & & & & & 1 & & & & 1 & \\
\hline Crônica & 1 & & & & & & & & & & & 1 & \\
\hline Diário & 1 & & & & & & & & & & & 1 & \\
\hline Gráfico & 1 & & & & & & & & & & & 1 & \\
\hline Horóscopo & & 1 & & & & & & & & & & 1 & \\
\hline Instrução & & 1 & & & & & & & & & & 1 & \\
\hline Prosa poética & & & & 1 & & & & & & & & 1 & \\
\hline TOTAL & 22 & 16 & 21 & 20 & 31 & 24 & 14 & 17 & 8 & 16 & 19 & 208 & \\
\hline
\end{tabular}

Observações:

1) $\mathrm{Na}$ contagem, consideramos, no caso dos poemas, contos, notícias, músicas, cartas, peças teatrais, sermões, cantigas, artigos, críticas, crônicas, diários, prosas poéticas, tanto os textos completos como trechos deles.

2) Como trechos de livros consideramos textos teóricos.

3) O Bate-papo que aparece na unidade 6 é um diálogo em salas de batepapo na internet. 
4) Diálogos são falas de pessoas, para os quais não são apresentados nem contextos nem referências bibliográficas.

5) As ocorrências cartas que aparecem nesse livro didático são trechos da Carta de Caminha.

6) Como artigos, consideramos todos os textos de jornais e revistas que não são notícias.

Observamos no presente livro didático que, com relação à quantidade, o gênero discursivo que mais aparece é o poema e os que menos aparecem são: bate-papo, crítica, crônica, diário, gráfico, horóscopo, instrução e prosa poética.

Os gráficos abaixo resumem os números coletados na tabela anterior em cada unidade do livro didático em questão.

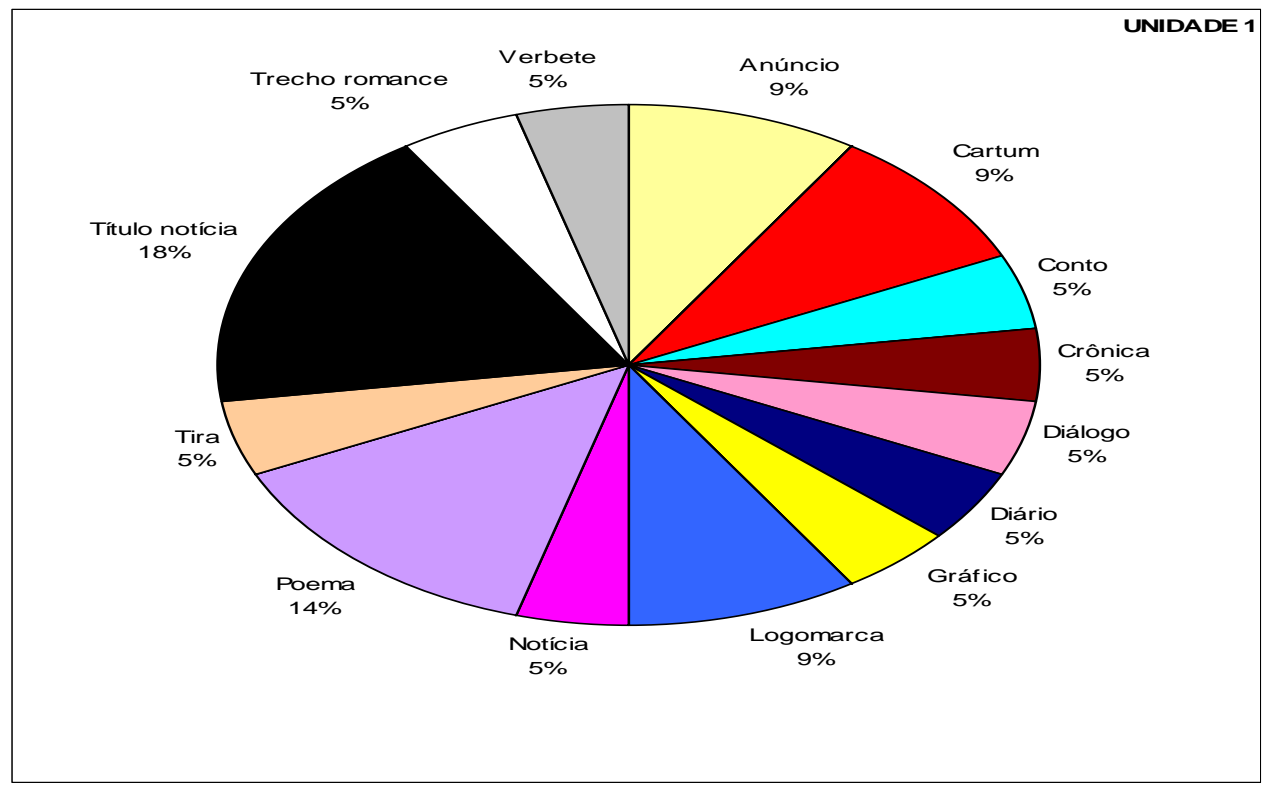

Gráfico 3.1 Gêneros contemplados na unidade 1 


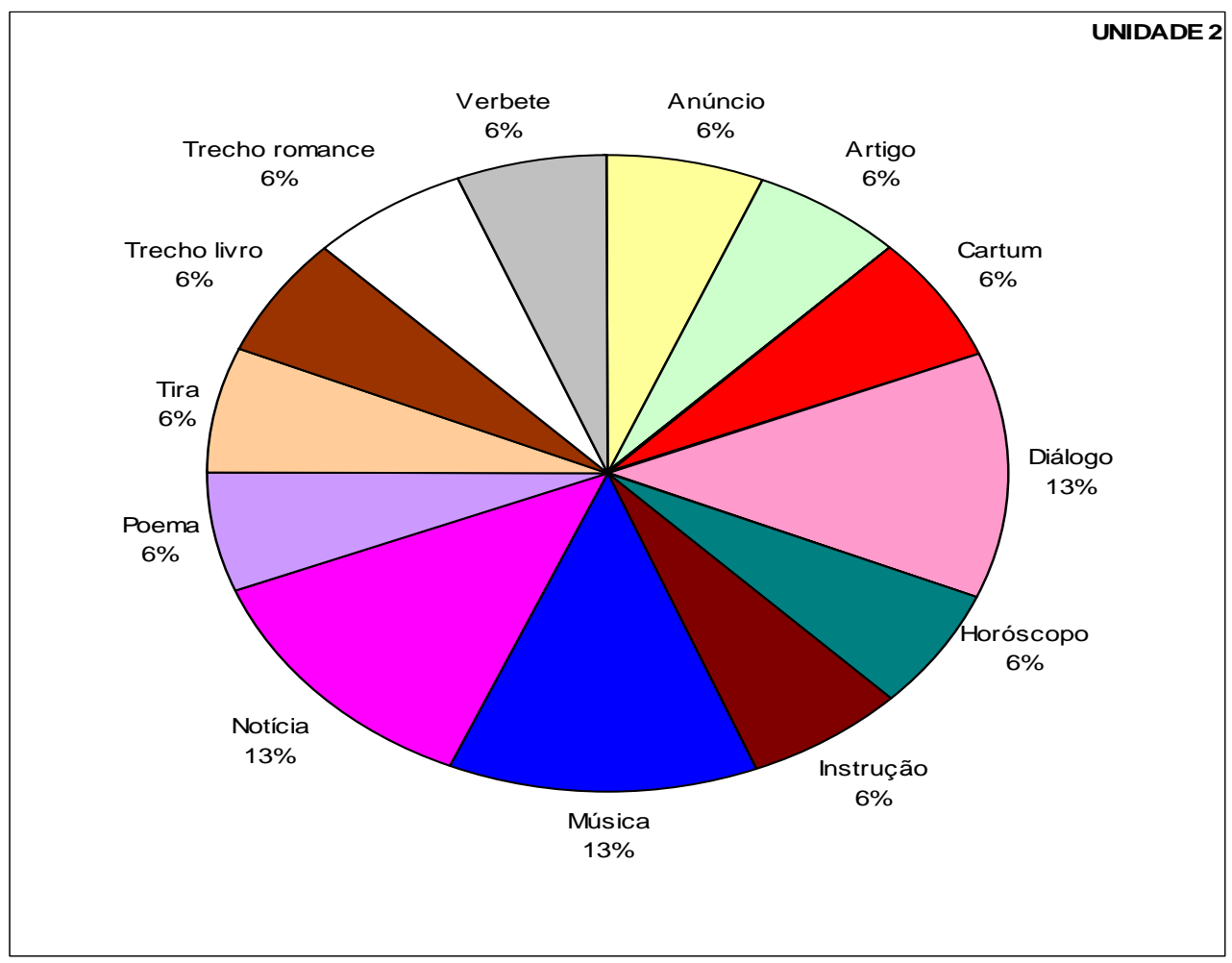

Gráfico 3.2 Gêneros contemplados na unidade 2

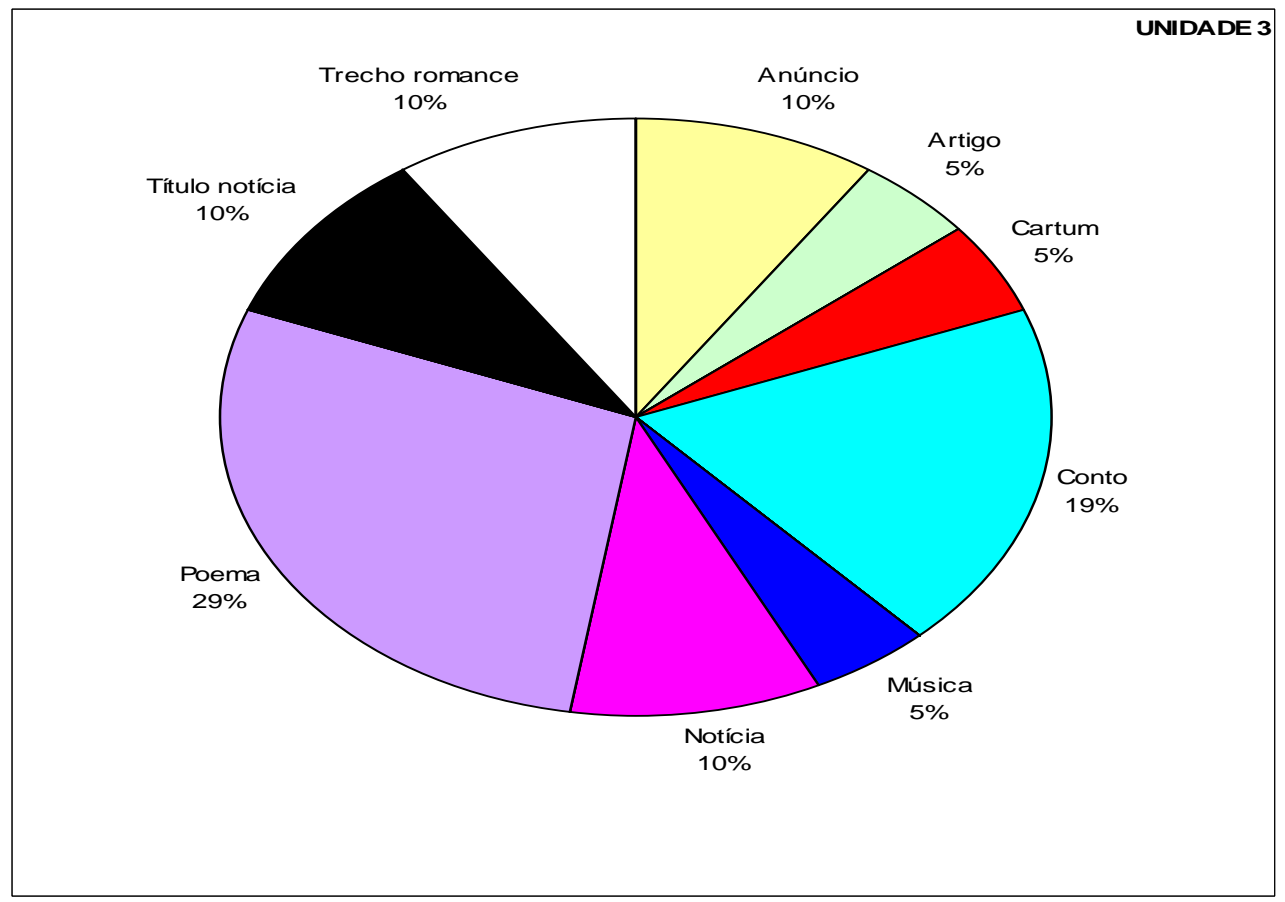

Gráfico 3.3 Gêneros contemplados na unidade 3 
59

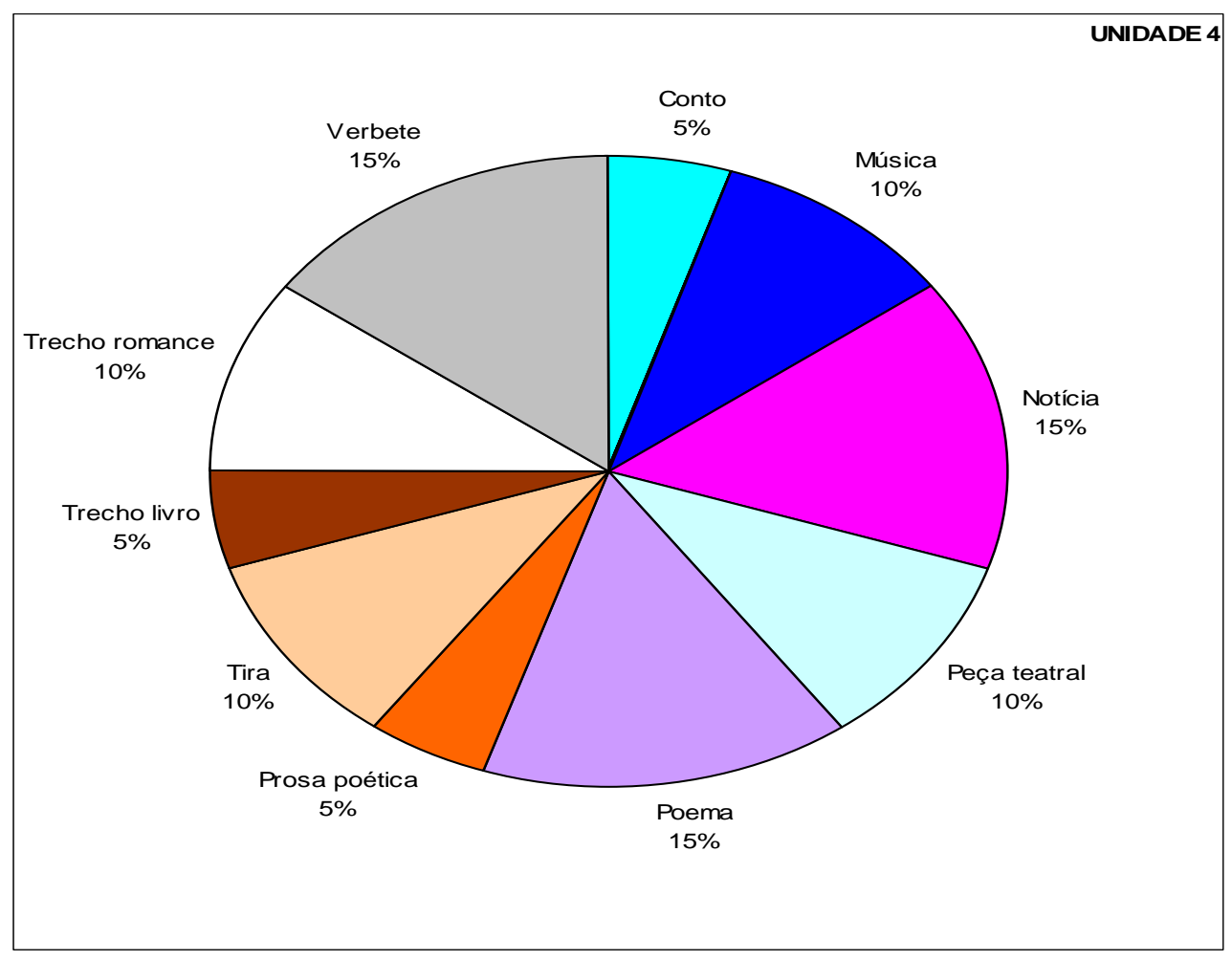

Gráfico 3.4 Gêneros contemplados na unidade 4

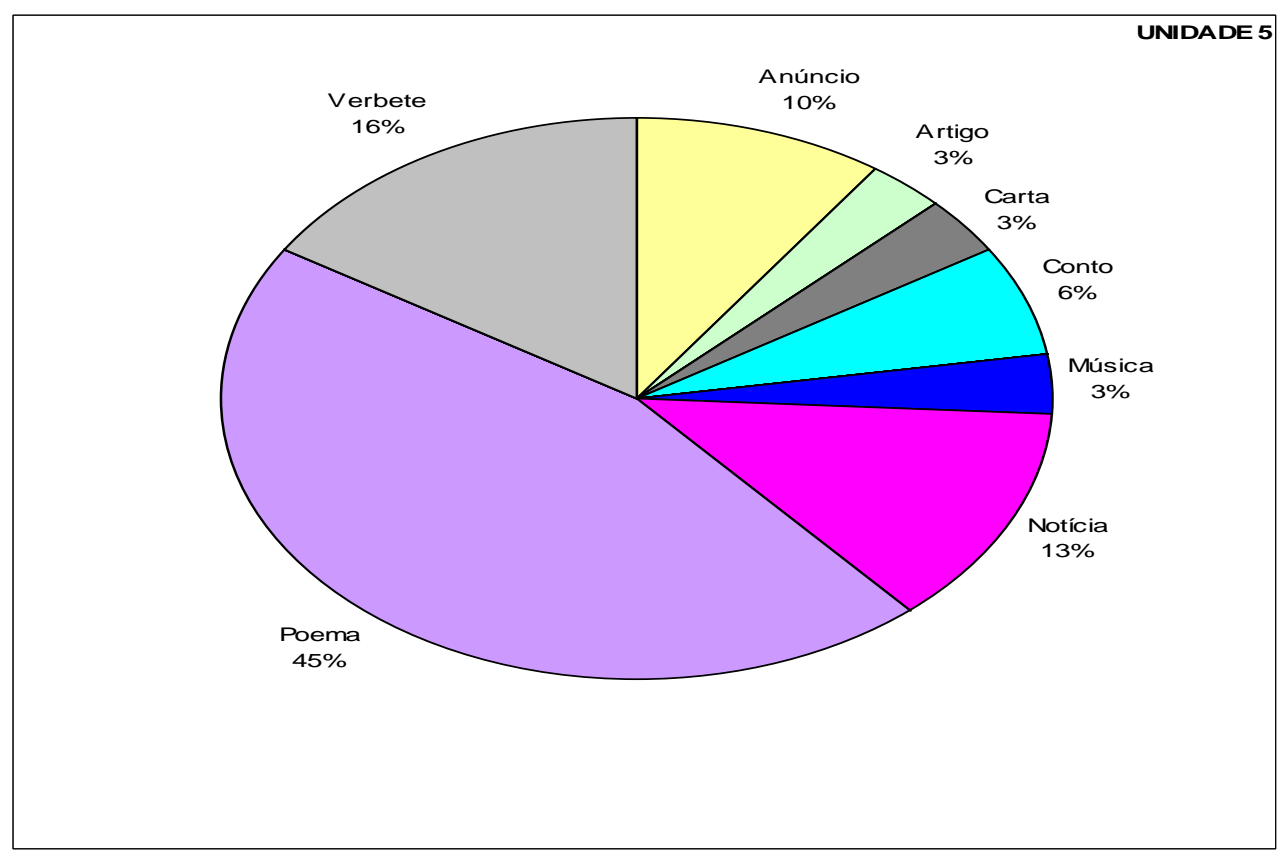

Gráfico 3.5 Gêneros contemplados na unidade 5 
60

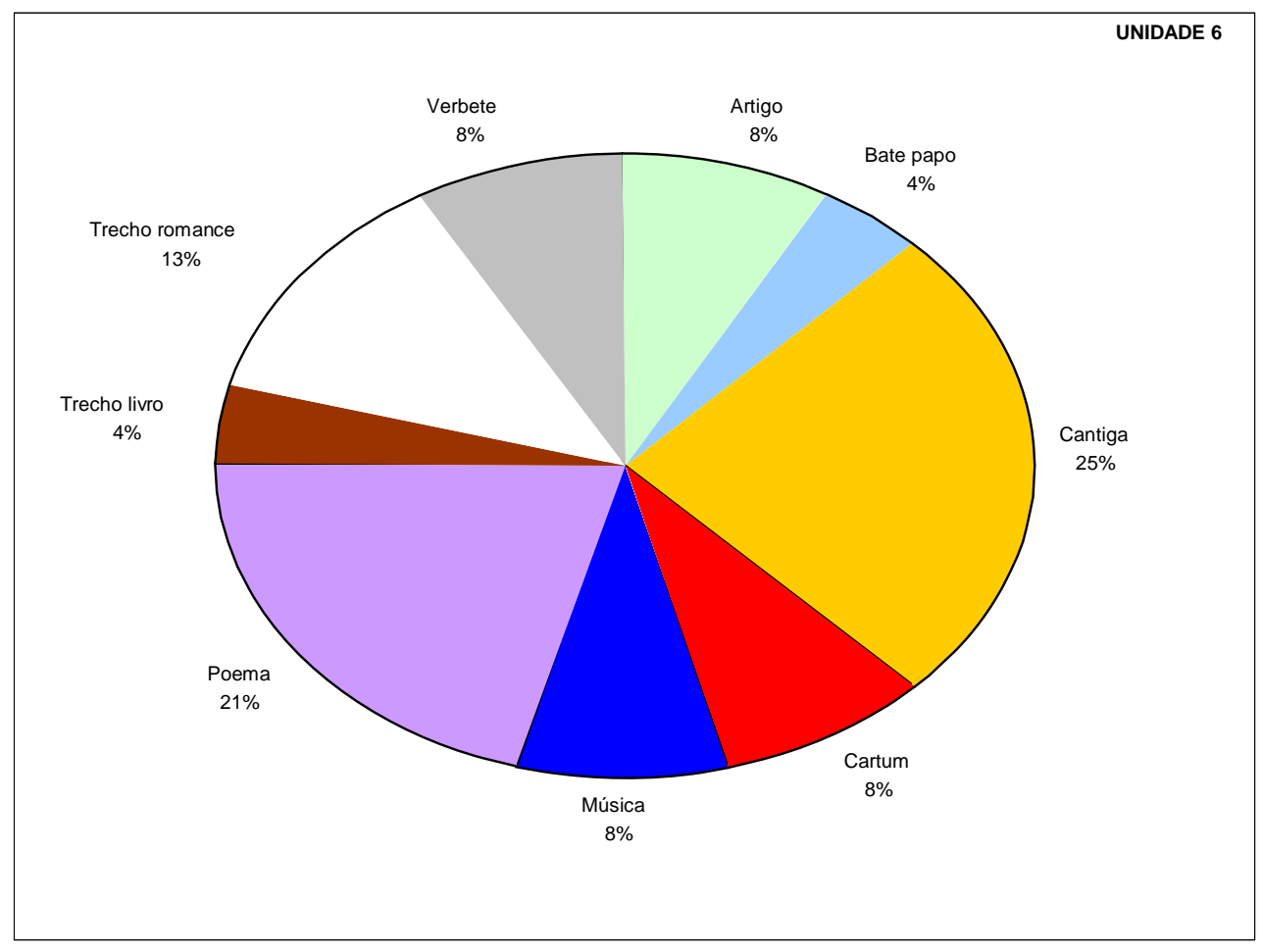

Gráfico 3.6 Gêneros contemplados na unidade 6

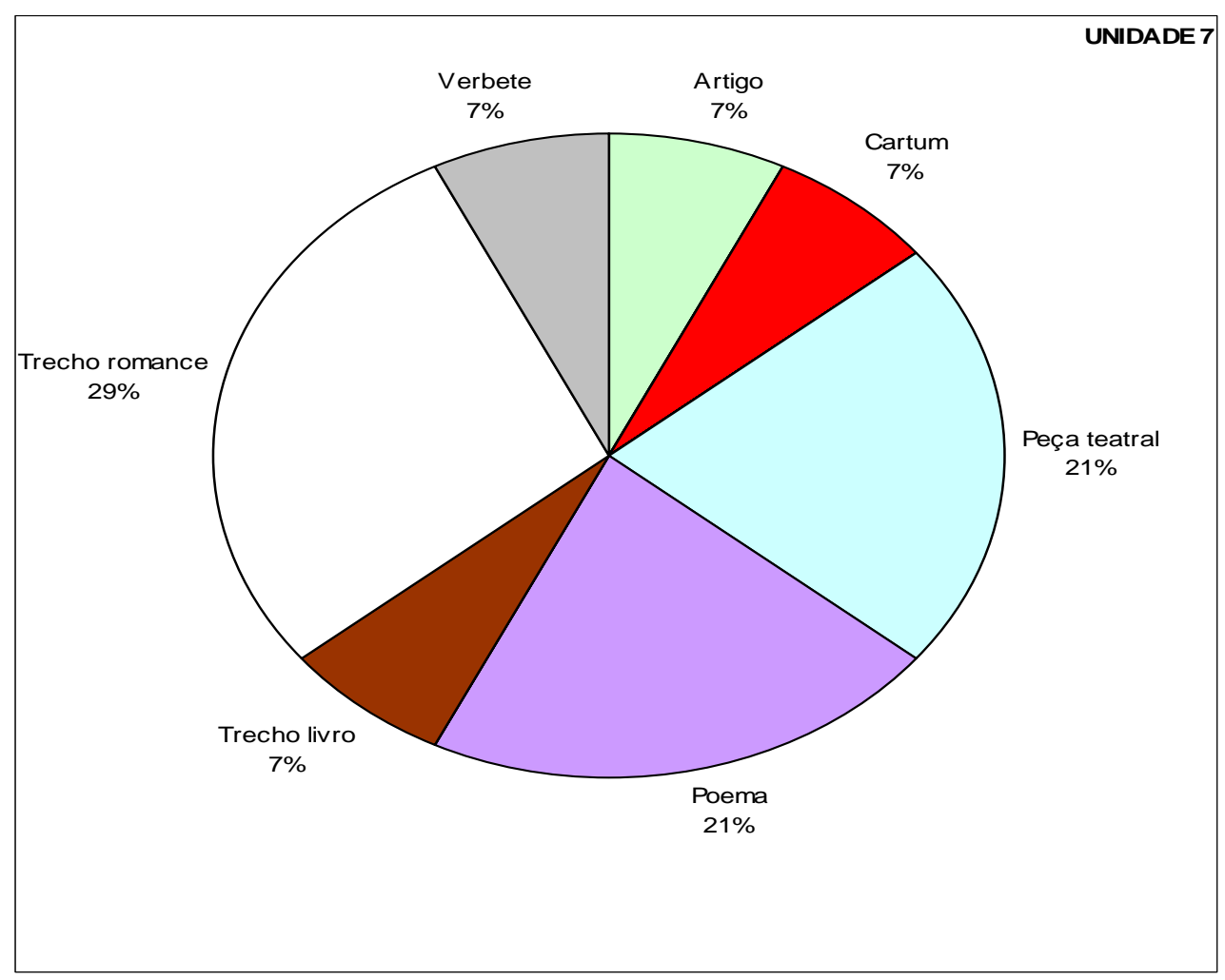

Gráfico 3.7 Gêneros contemplados na unidade 7 


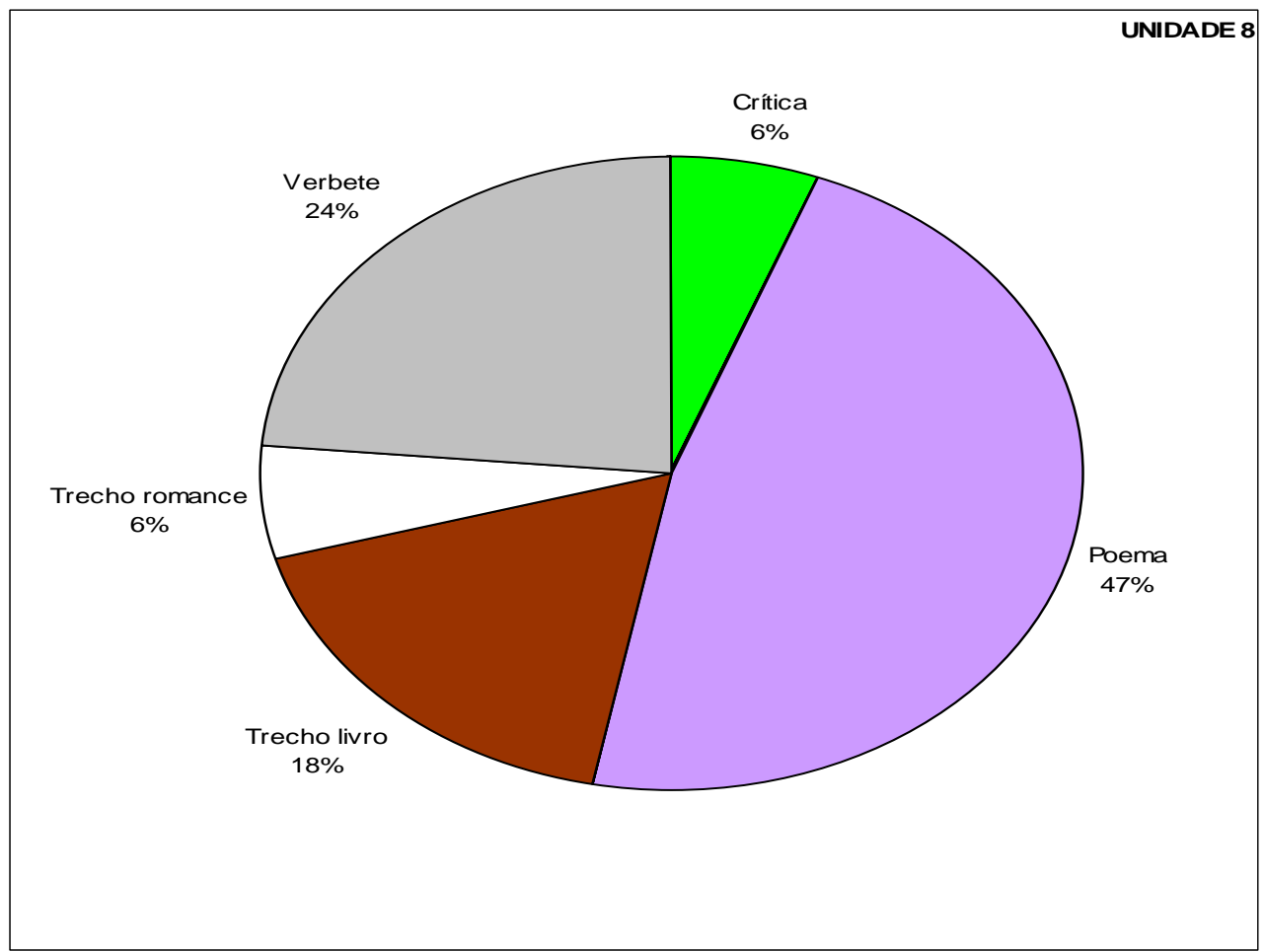

Gráfico 3.8 Gêneros contemplados na unidade 8

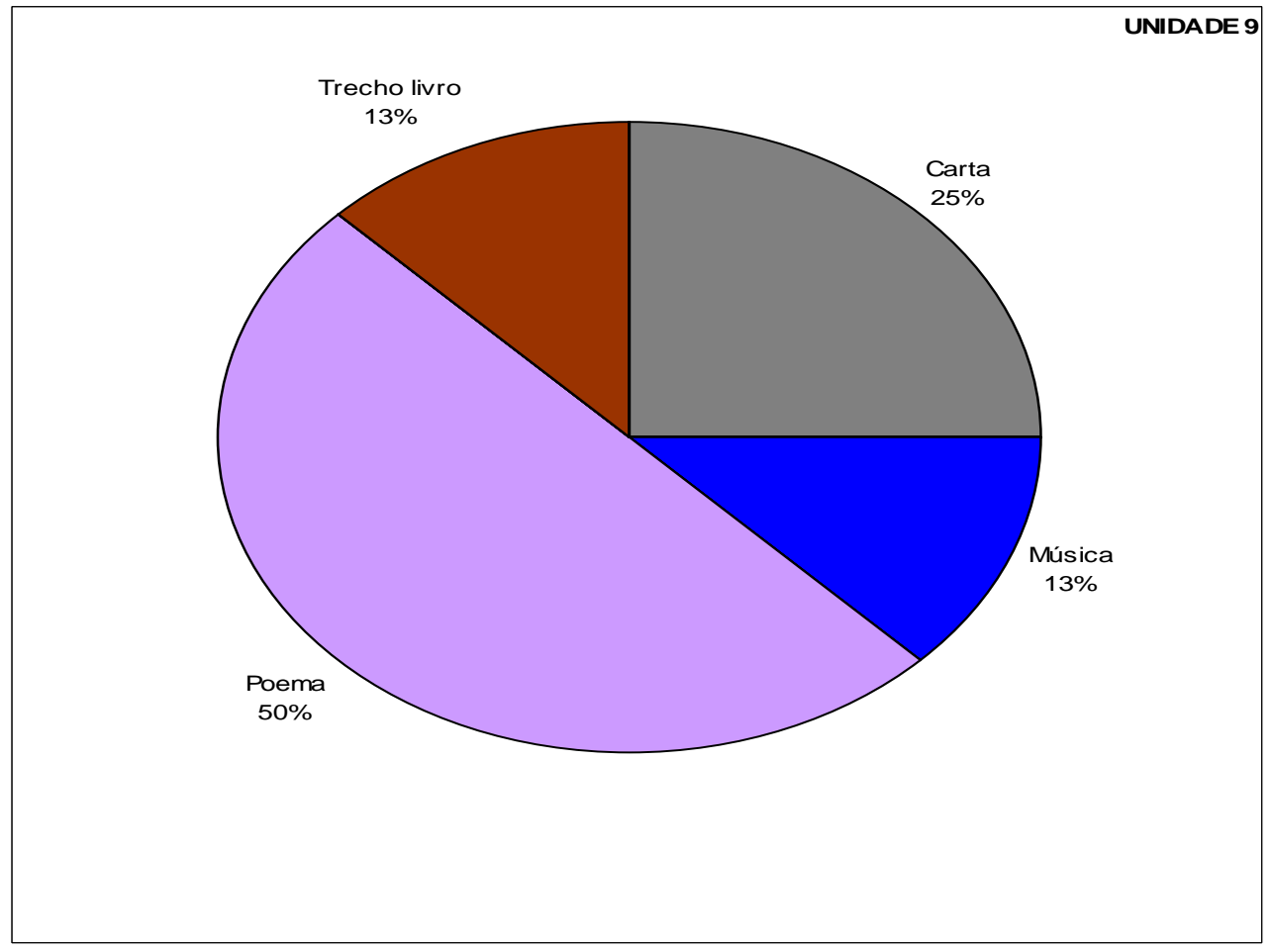

Gráfico 3.9 Gêneros contemplados na unidade 9 


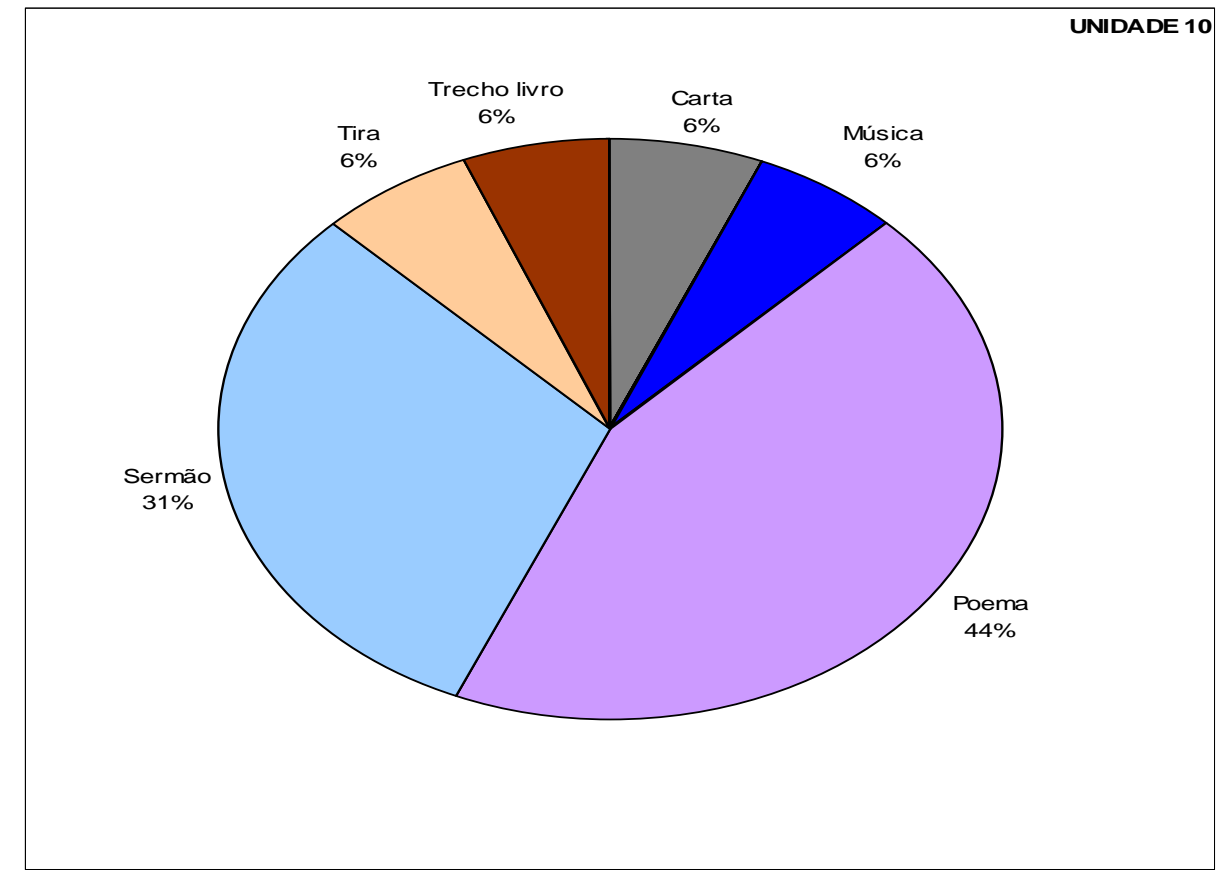

Gráfico 3.10 Gêneros contemplados na unidade 10

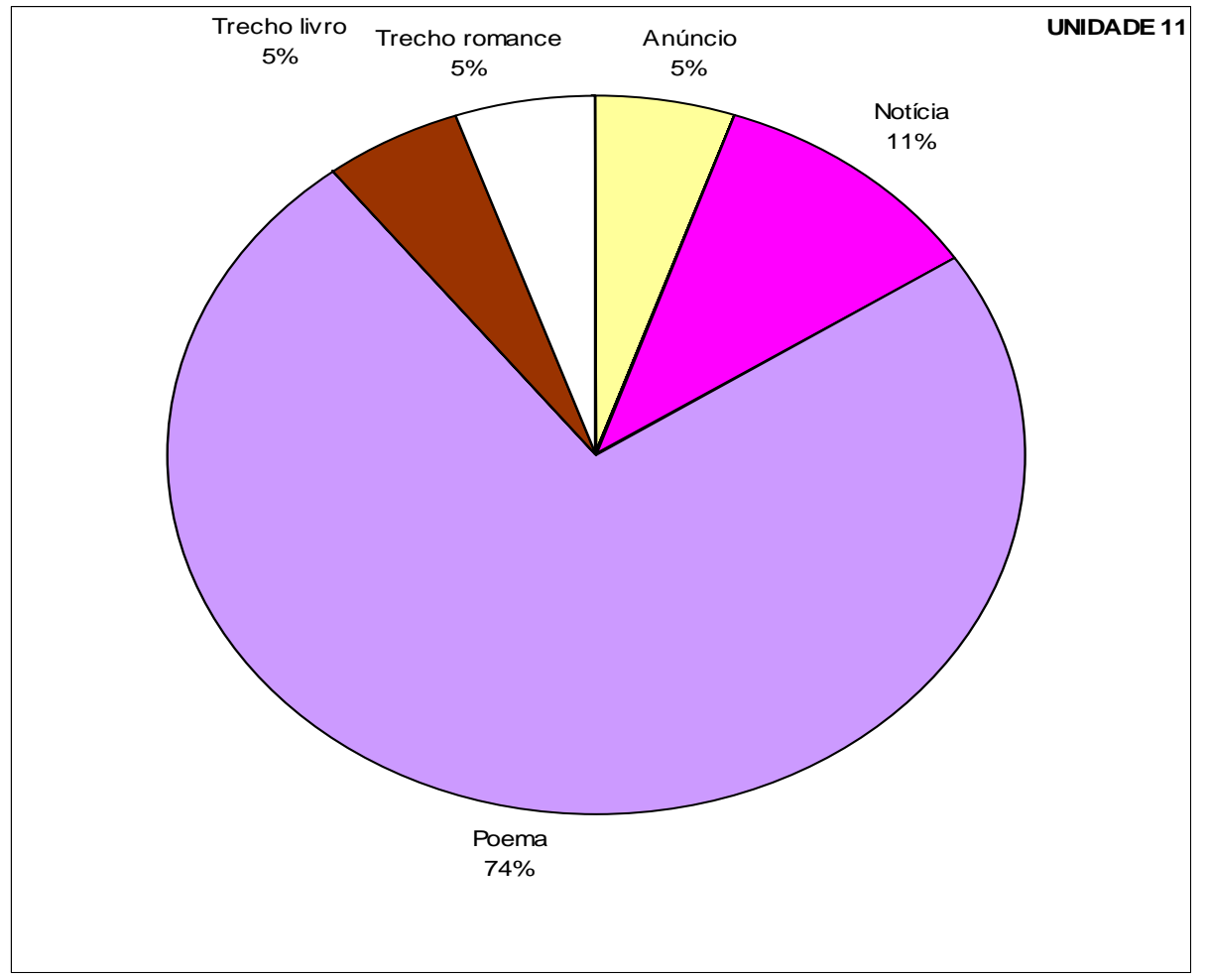

Gráfico 3.11 Gêneros contemplados na unidade 11 
Notamos que no Língua e Literatura aparecem 208 ocorrências de gêneros discursivos, destas 68 são poemas, representando 33\%, com apenas uma ocorrência (menos de 1\%) encontramos o bate-papo, a crítica, a crônica, o diálogo, o diário, o gráfico, o horóscopo, a instrução e a prosa poética.

Observamos que a quantidade de gêneros discursivos estudados em cada unidade está relativamente em equilíbrio, aparecem nas unidades de 14 a 24 ocorrências, exceto a unidade 9 que traz apenas 8 ocorrências. Quanto à diversidade delas, não encontramos a mesma realidade, em algumas unidades aparecem 13 gêneros diferentes em outras somente 4 ou 5 gêneros. Consideramos pertinente comentar que as primeiras unidades do livro apresentam mais diversidade de gêneros discursivos que as últimas.

Pensamos ser relevante mostrar, a seguir, um gráfico geral que representa todos os gêneros discursivos encontrados no livro Língua e Literatura em todos as suas 11 unidades.

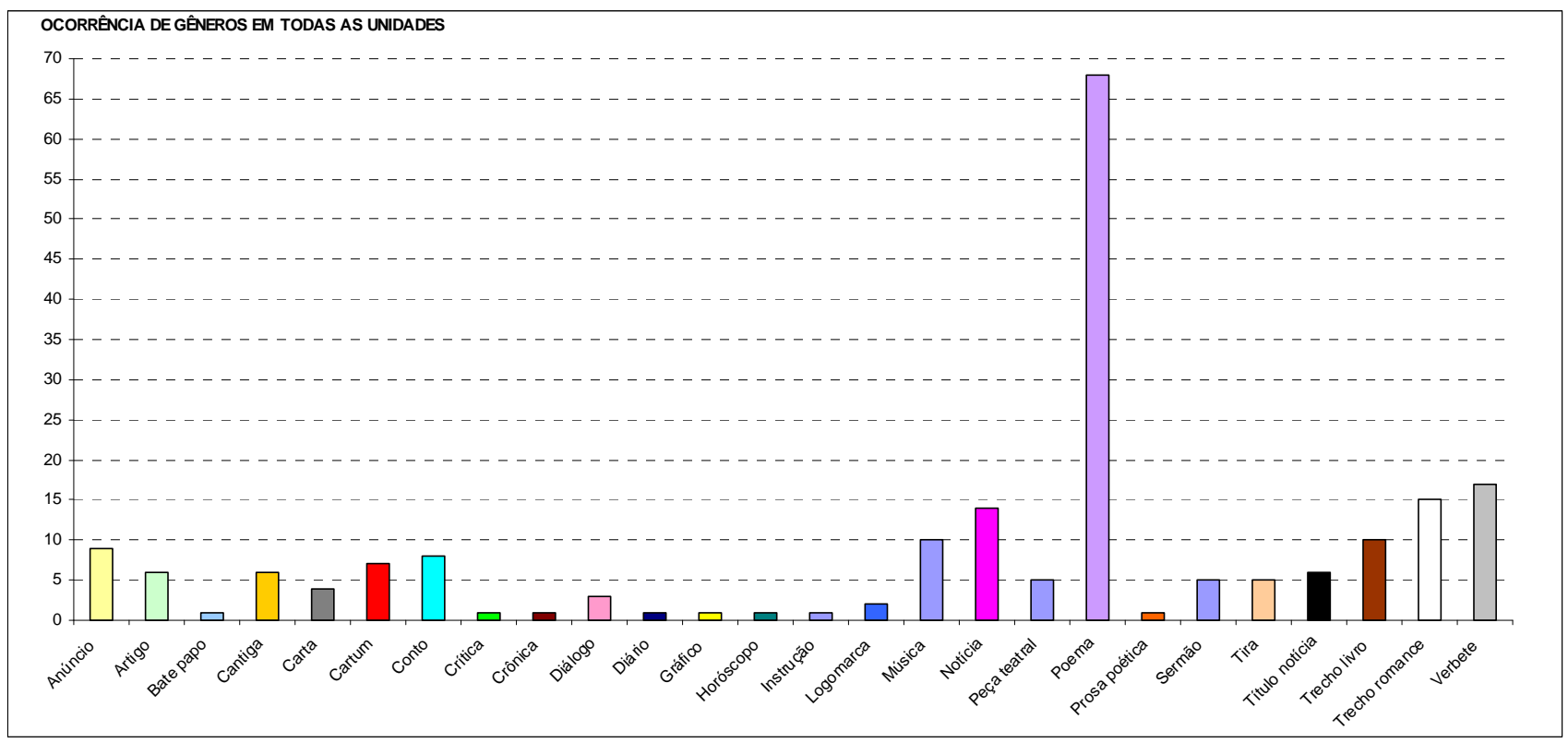

Gráfico 3.12 Gêneros discursivos no livro Língua e Literatura 


\subsection{Língua, Literatura e Produção de Textos}

O livro possui 3 partes e cada parte está dividida em capítulos. A parte 1 , intitulada "Formando o leitor e o produtor de texto: as estruturas gramaticais dos textos" tem 8 capítulos; a parte 2, "Formando o leitor e o produtor de texto: os textos do cotidiano", tem 9 capítulos e a parte 3, "Formando o leitor e produtor de texto: os textos artísticos", tem 10 capítulos. Na parte 2, há um capítulo chamado "Gêneros e tipos textuais no cotidiano".

Os gêneros discursivos que aparecem na obra são muito diversos e estão distribuídos em todas as partes. Apresentaremos uma tabela com todos os gêneros discursivos e as ocorrências que aparecem por partes do livro.

Observações:

1) $\mathrm{Na}$ contagem, consideramos, no caso dos poemas, contos, notícias, músicas, cartas, peças teatrais, sermões, cantigas, artigos, crônicas, biografia, entrevistas, tanto os textos completos como trechos deles.

2) Como trechos de livros consideramos textos teóricos.

3) O Bate-papo que aparece na parte 2 é um diálogo em salas de bate-papo na internet.

4) Documentos eletrônicos são textos que só apresentam como fonte um endereço eletrônico.

5) As ocorrências cartas que aparecem nesse didático são trechos da Carta de Caminha.

6) Como artigos, consideramos todos os textos de jornais e revistas que não são notícias.

7) As críticas encontradas no livro didático são críticas a filmes, livros etc.

8) Como constituição, consideramos um artigo da constituição brasileira que serviu como subsídio para exercícios do livro. 
Tabela 3.2 Gêneros discursivos no livro Língua, Literatura e Produção de Textos

\begin{tabular}{|c|c|c|c|c|c|}
\hline G Ê N E R O & PARTE 1 & PARTE 2 & PARTE 3 & TO T A L & $\%$ \\
\hline Poem a & 3 & 30 & 68 & 101 & $31 \%$ \\
\hline Trecho livro & 1 & 13 & 13 & 27 & $8 \%$ \\
\hline Doc.eletrônico & 8 & 14 & 1 & 23 & $7 \%$ \\
\hline Trechorom ance & 2 & 15 & 4 & 21 & $6 \%$ \\
\hline Artigo & 8 & 10 & 2 & 20 & $6 \%$ \\
\hline Notícia & 10 & 8 & & 18 & $5 \%$ \\
\hline Tira & 5 & 11 & 1 & 17 & $5 \%$ \\
\hline Cantiga & & 2 & 14 & 16 & $5 \%$ \\
\hline Música & 3 & 5 & 8 & 16 & $5 \%$ \\
\hline Peça teatral & & & 9 & 9 & $3 \%$ \\
\hline Conto & 2 & 5 & & 7 & $2 \%$ \\
\hline A núncio & 3 & 3 & & 6 & $2 \%$ \\
\hline Título notícia & 5 & & & 5 & $2 \%$ \\
\hline Verbete & 2 & 1 & 2 & 5 & $2 \%$ \\
\hline Carta & & 1 & 3 & 4 & $1 \%$ \\
\hline Serm ão & 1 & & 3 & 4 & $1 \%$ \\
\hline Crítica & 1 & & 2 & 3 & $1 \%$ \\
\hline Receita & 1 & 2 & & 3 & $1 \%$ \\
\hline Cartum & 1 & 1 & & 2 & $1 \%$ \\
\hline Charge & & 2 & & 2 & $1 \%$ \\
\hline Classificado & 1 & 1 & & 2 & $1 \%$ \\
\hline Crônica & & 1 & 1 & 2 & $1 \%$ \\
\hline Placa & 2 & & & 2 & $1 \%$ \\
\hline Trecho filme & & 2 & & 2 & $1 \%$ \\
\hline B a te-papo & & 1 & & 1 & \multirow{12}{*}{$4 \%$} \\
\hline Biografia & & 1 & & 1 & \\
\hline B u la & & 1 & & 1 & \\
\hline Cartaz & & 1 & & 1 & \\
\hline Constituição & & 1 & & 1 & \\
\hline Entrevista & & 1 & & 1 & \\
\hline Horóscopo & & 1 & & 1 & \\
\hline O ração & & 1 & & 1 & \\
\hline Previsão tem po & 1 & & & 1 & \\
\hline R e dação aluno & & 1 & & 1 & \\
\hline Slogan & & 1 & & 1 & \\
\hline Texto bíblico & & & 1 & 1 & \\
\hline TO T A L & 60 & 137 & 132 & 329 & \\
\hline
\end{tabular}

Observamos pela tabela que no presente livro didático, com relação à quantidade, há 329 ocorrências de gêneros discursivos, sendo o poema 101 dessas ocorrências (31\%) e com apenas 1 ocorrência (menos de 1\%): o bate- 
papo, a biografia, a bula, o cartaz, a constituição, a entrevista, o horóscopo, a oração, a previsão do tempo, a redação de aluno, o slogan, o texto bíblico.

Percebemos que a quantidade de gêneros discursivos estudados em cada parte do livro varia de 60 a 137. Quanto à diversidade dos gêneros discursivos, encontramos na parte 1, 19 gêneros diferentes, na parte 2, 29 gêneros e na parte 3 , apenas 15. Consideramos pertinente comentar que nas duas primeiras partes do livro há maior diversidade de gêneros e na última, menor diversidade.

Os gráficos, a seguir, resumem os números coletados na tabela anterior em cada parte do livro didático em questão.

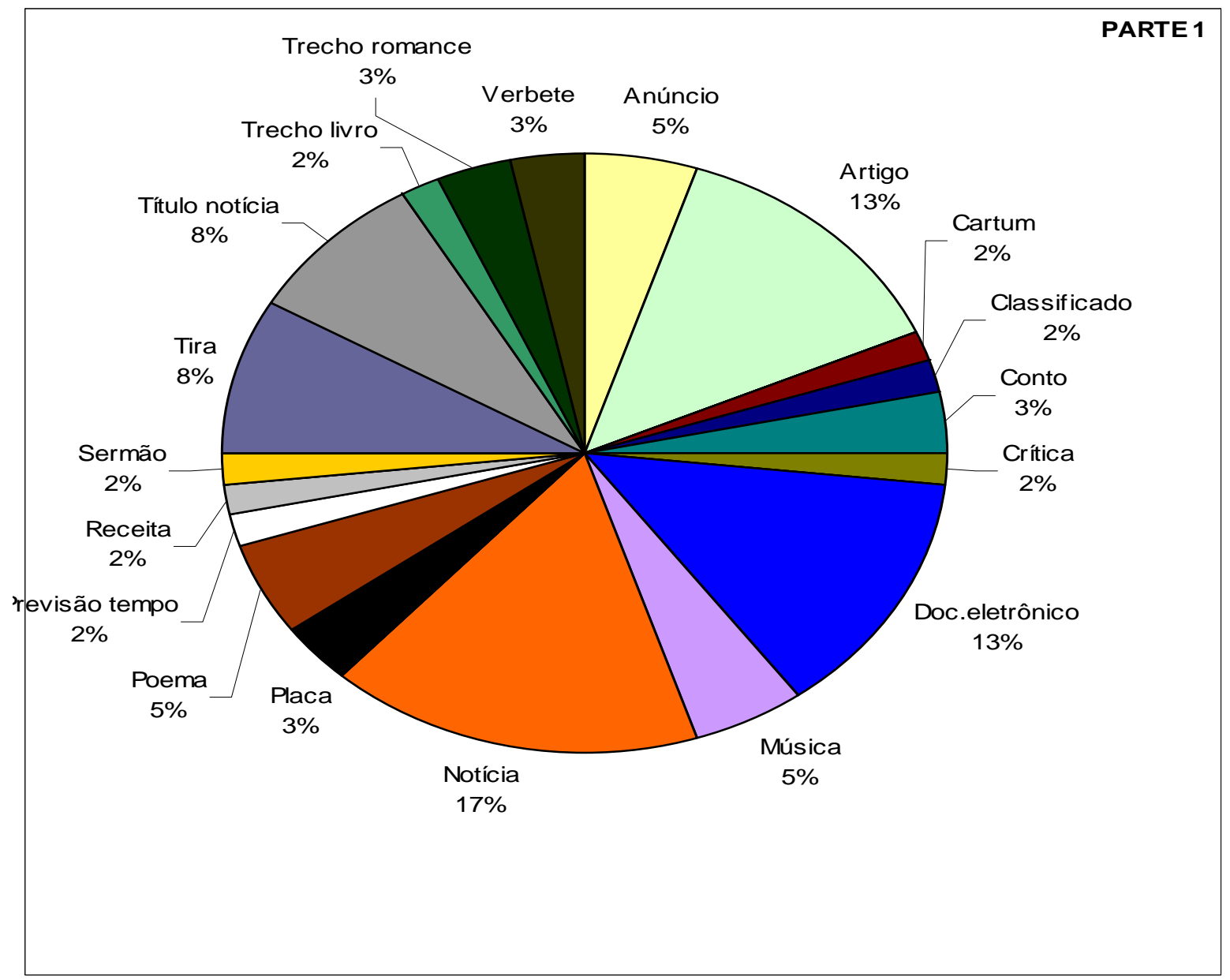

Gráfico 3.13 Gêneros contemplados na parte 1 


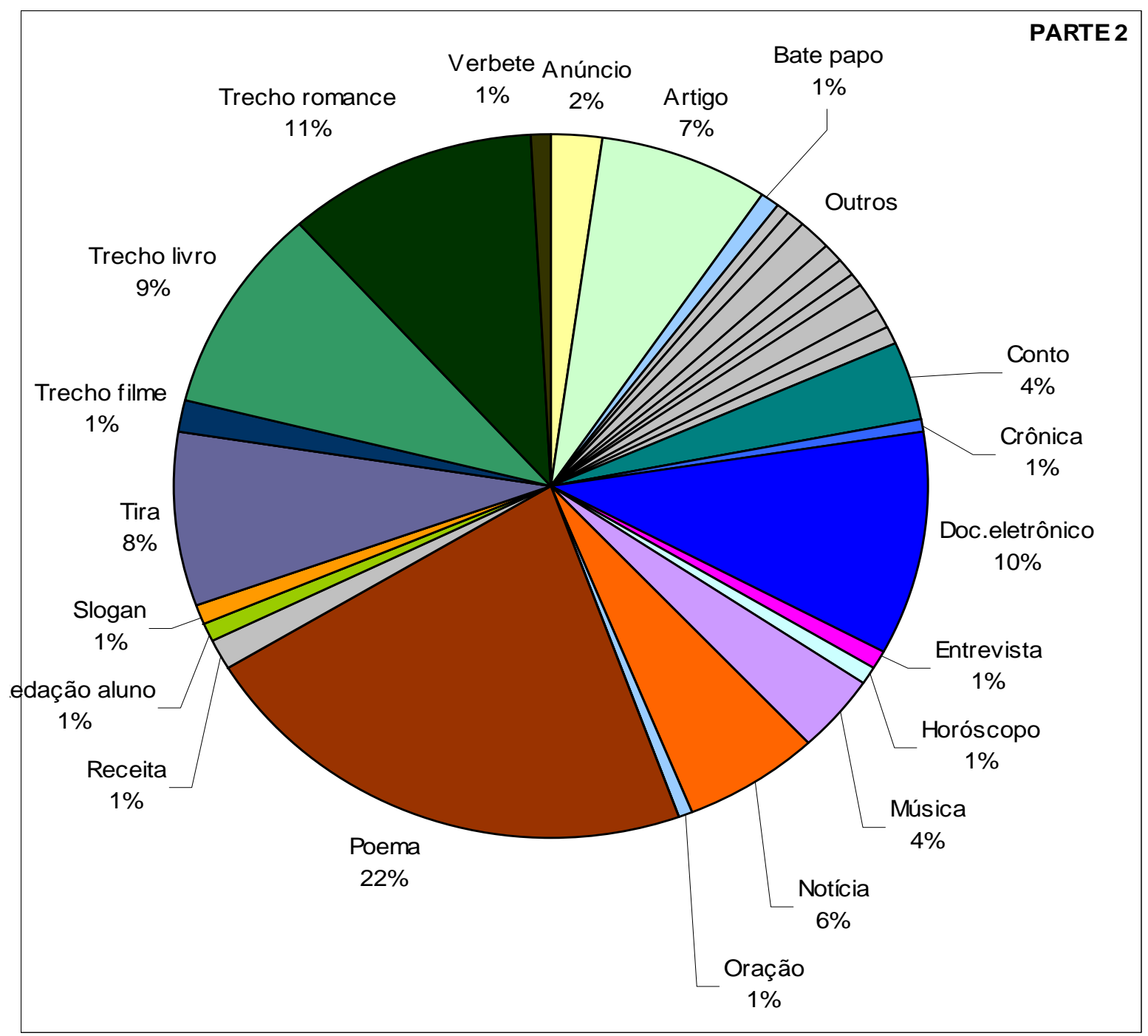

\section{Gráfico 3.14 Gêneros contemplados na parte 2}

Observação:

- Dada a excessiva diversidade de gêneros discursivos que aparece nesta parte 2 do livro didático e a dificuldade de representá-los no gráfico, consideramos como outros: biografia, bula, cartaz, constituição, previsão do tempo, texto bíblico. 


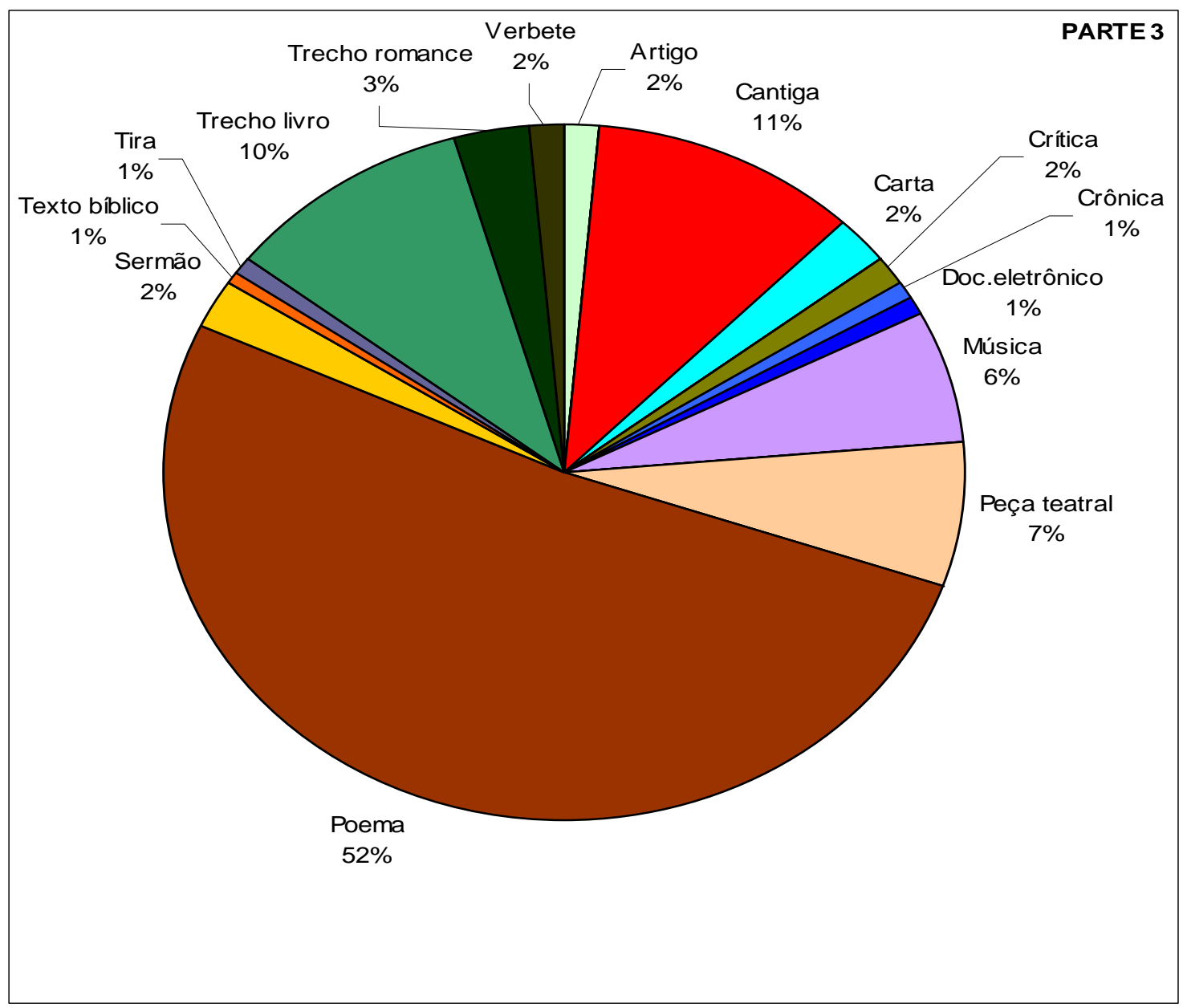

\section{Gráfico 3.15 Gêneros contemplados na parte 3}

Apresentamos, a seguir, um gráfico geral que representa todos os gêneros discursivos encontrados nas três partes do livro Língua, Literatura e produção de textos. 


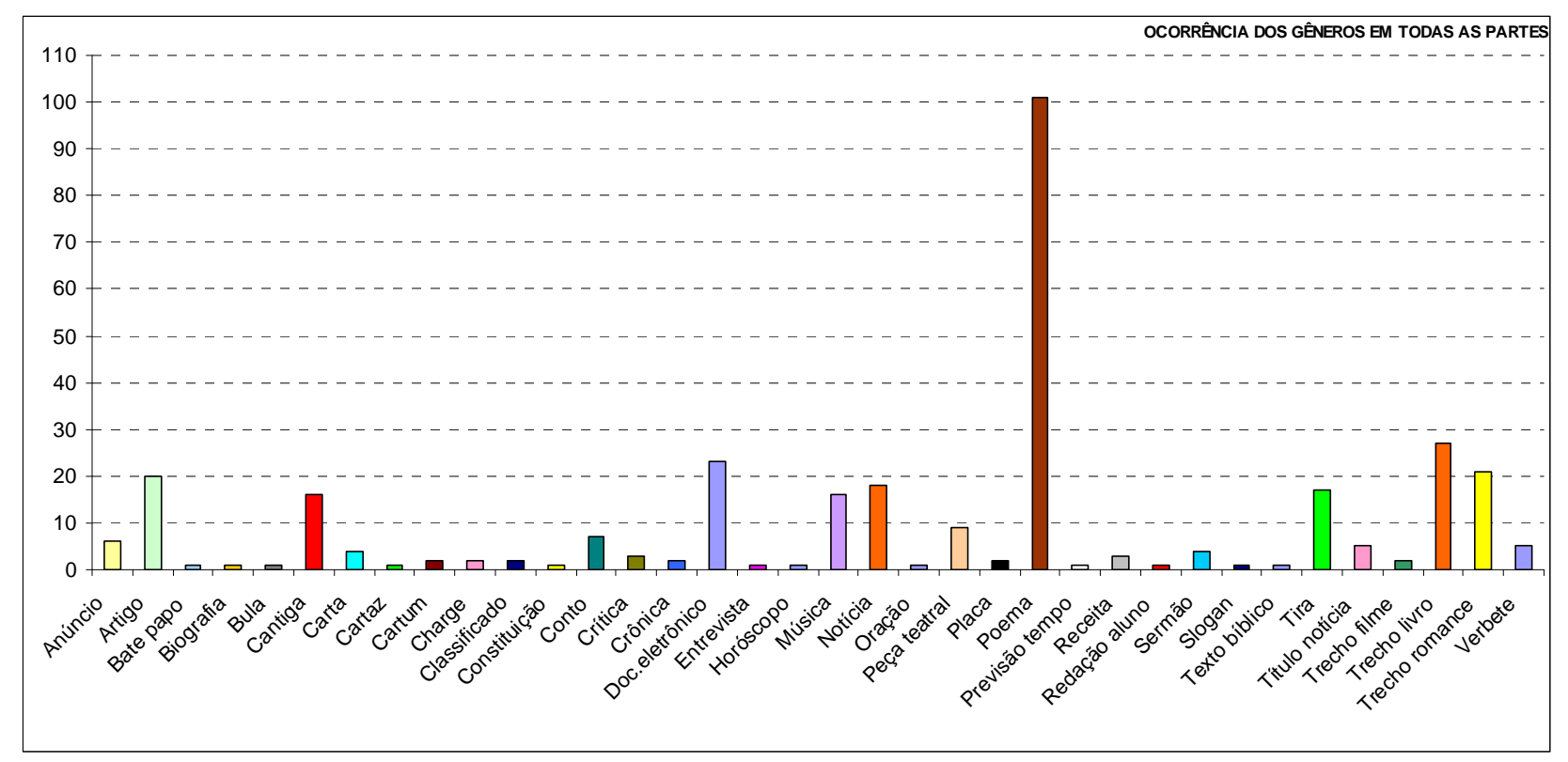

Gráfico 3.16 Gêneros discursivos no livro Língua, Literatura e Produção de Textos

\subsection{Português Linguagens}

O livro Português Linguagens possui 4 unidades distribuídas em 43 capítulos. A unidade 1 comporta os capítulos de 1 a 12; a unidade 2, comporta os capítulos de 13 a 22; a unidade 3, os capítulos de 23 a 33 e a unidade 4, os capítulos de 34 a 43 .

Os títulos dos capítulos são: Língua: uso e reflexão, Literatura e Produção de texto. Os capítulos destinados à produção de texto começam com uma "Introdução aos gêneros do discurso", explicando o que é gênero textual e os capítulos que seguem têm como proposta trabalhar um gênero. O autor utiliza a classificação gêneros textuais: "Esses tipos de textos constituem os chamados gêneros textuais [...]" (CEREJA E MAGALHÃES,2004, p.46-47).

Os gêneros discursivos que se propõem trabalhar em 12 capítulos, são: a fábula, o poema, o texto teatral escrito, a carta pessoal, o relato pessoal, o diário e o blog, o texto de campanha comunitária, o relatório de experiência científica, o 
seminário, o debate regrado público, o artigo de opinião e o debate e artigo de opinião. Em cada uma dessas propostas, o livro traz uma explicação e exemplos de textos no referido gênero discursivo e depois uma proposta para produção daquele gênero.

Além dos gêneros discursivos acima, o livro traz outros diversos gêneros, como podemos observar na tabela a seguir:

Observações:

1) $\mathrm{Na}$ contagem, consideramos, no caso dos poemas, contos, notícias, músicas, cartas, peças teatrais, sermões, cantigas, artigos, crônicas, fábulas, relatórios, depoimentos, relatos, tanto os textos completos como trechos deles.

2) Como trechos de livros consideramos textos teóricos.

3) Documentos eletrônicos são textos que só apresentam como fonte um endereço eletrônico.

4) As ocorrências cartas que aparecem nesse didático são trechos da Carta de Caminha assim como cartas pessoais de pessoas famosas e de pessoas comuns.

5) Como artigos, consideramos todos os textos de jornais e revistas que não são notícias.

6) As críticas encontradas no didático são críticas a filmes, livros etc. 
Tabela 3.3 Gêneros discursivos no livro Português Linguagens

\begin{tabular}{|c|c|c|c|c|c|c|}
\hline GÊNERO & $\begin{array}{c}\text { UNIDADE } \\
1\end{array}$ & $\begin{array}{c}\text { UNIDADE } \\
\mathbf{2} \\
\end{array}$ & $\begin{array}{c}\text { UNIDADE } \\
\mathbf{3} \\
\end{array}$ & $\begin{array}{c}\text { UNIDADE } \\
4\end{array}$ & TOTAL & $\%$ \\
\hline Poema & 28 & 24 & 17 & 26 & 95 & $32 \%$ \\
\hline Tira & 6 & 9 & 17 & 9 & 41 & $14 \%$ \\
\hline Artigo & 4 & 5 & 8 & 13 & 30 & $10 \%$ \\
\hline Trecho livro & 13 & 2 & 6 & 4 & 25 & $8 \%$ \\
\hline Anúncio & 7 & 6 & 6 & 3 & 22 & $7 \%$ \\
\hline Cantiga & 11 & 2 & & & 13 & $4 \%$ \\
\hline Trecho romance & 9 & 2 & 2 & & 13 & $4 \%$ \\
\hline Carta & 2 & 4 & 1 & & 7 & $2 \%$ \\
\hline Música & 2 & 2 & 2 & & 6 & $2 \%$ \\
\hline Fábula & 5 & & & & 5 & $2 \%$ \\
\hline Peça teatral & 4 & & & & 4 & $1 \%$ \\
\hline Relatório & & & 4 & & 4 & $1 \%$ \\
\hline Cartum & 1 & 1 & 1 & & 3 & $1 \%$ \\
\hline Doc.eletrônico & 3 & & & 1 & 3 & $1 \%$ \\
\hline Notícia & 1 & 2 & & 1 & 3 & $1 \%$ \\
\hline Sermão & & & 3 & & 3 & $1 \%$ \\
\hline Conto & 2 & & & & 2 & $1 \%$ \\
\hline Crítica & & 2 & & & 2 & $1 \%$ \\
\hline Provérbio & 2 & & & & 2 & $1 \%$ \\
\hline Blog & & 1 & & & 1 & \multirow{12}{*}{$4 \%$} \\
\hline Cartaz & 1 & & & & 1 & \\
\hline Cena filme & & & 1 & 3 & 1 & \\
\hline Charge & & 1 & & & 1 & \\
\hline Crônica & & 1 & & 1 & 1 & \\
\hline Depoimento & 1 & & & 3 & 1 & \\
\hline Dicas & 1 & & & & 1 & \\
\hline Diário & & 1 & & & 1 & \\
\hline Relato & & 1 & & & 1 & \\
\hline Slogan & 1 & & & & 1 & \\
\hline Texto bíblico & & 1 & & & 1 & \\
\hline Verbete & 1 & & & & 1 & \\
\hline TOTAL & 105 & 67 & 68 & 64 & 295 & \\
\hline
\end{tabular}

Pela tabela acima, observamos que no Português Linguagens há 295 ocorrências de gêneros discursivos, sendo 95 poemas, correspondendo a 32\% e com apenas 1 ocorrência (menos de 1\%) aparecem: o blog, o cartaz, a cena de filme, a charge, a crônica, o depoimento, as dicas, o diário, o relato, o slogan, o texto bíblico e o verbete.

Percebemos que a quantidade de gêneros discursivos trabalhados em cada unidade varia de 64 a 105. Quanto à diversidade dos gêneros discursivos, encontramos na unidade 1, 21 gêneros diferentes, na unidade 2, 18 gêneros, na 
unidade 3, 15 gêneros discursivos diferentes e na unidade 4, somente 10 . Observamos que nesse livro didático também há maior diversidade de gêneros discursivos nas duas primeiras unidades e nas duas últimas, menor diversidade.

Os gráficos, a seguir, resumem os números coletados na tabela anterior em cada unidade do livro didático em questão.

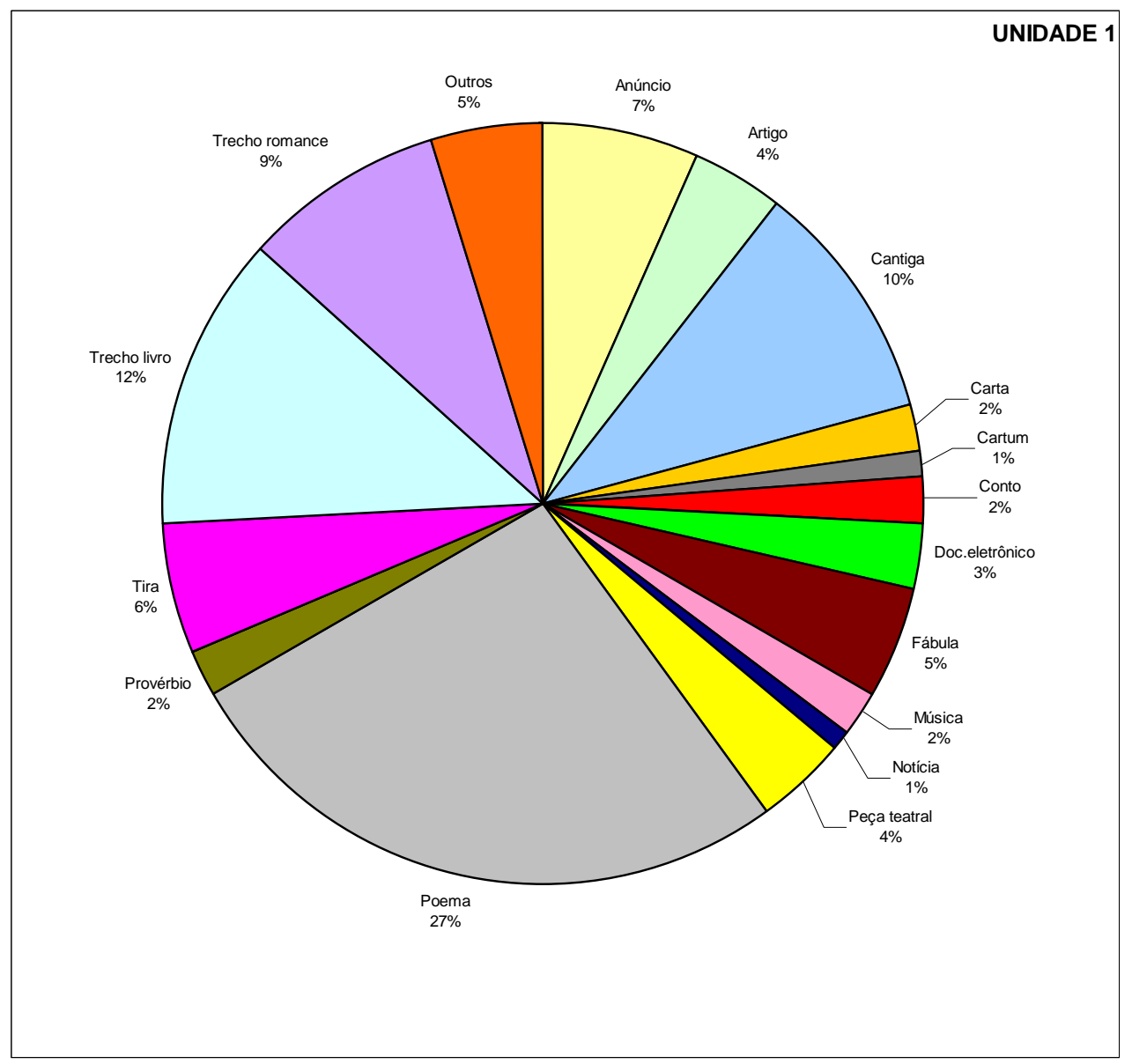

Gráfico 3.17 Gêneros contemplados na unidade 1 


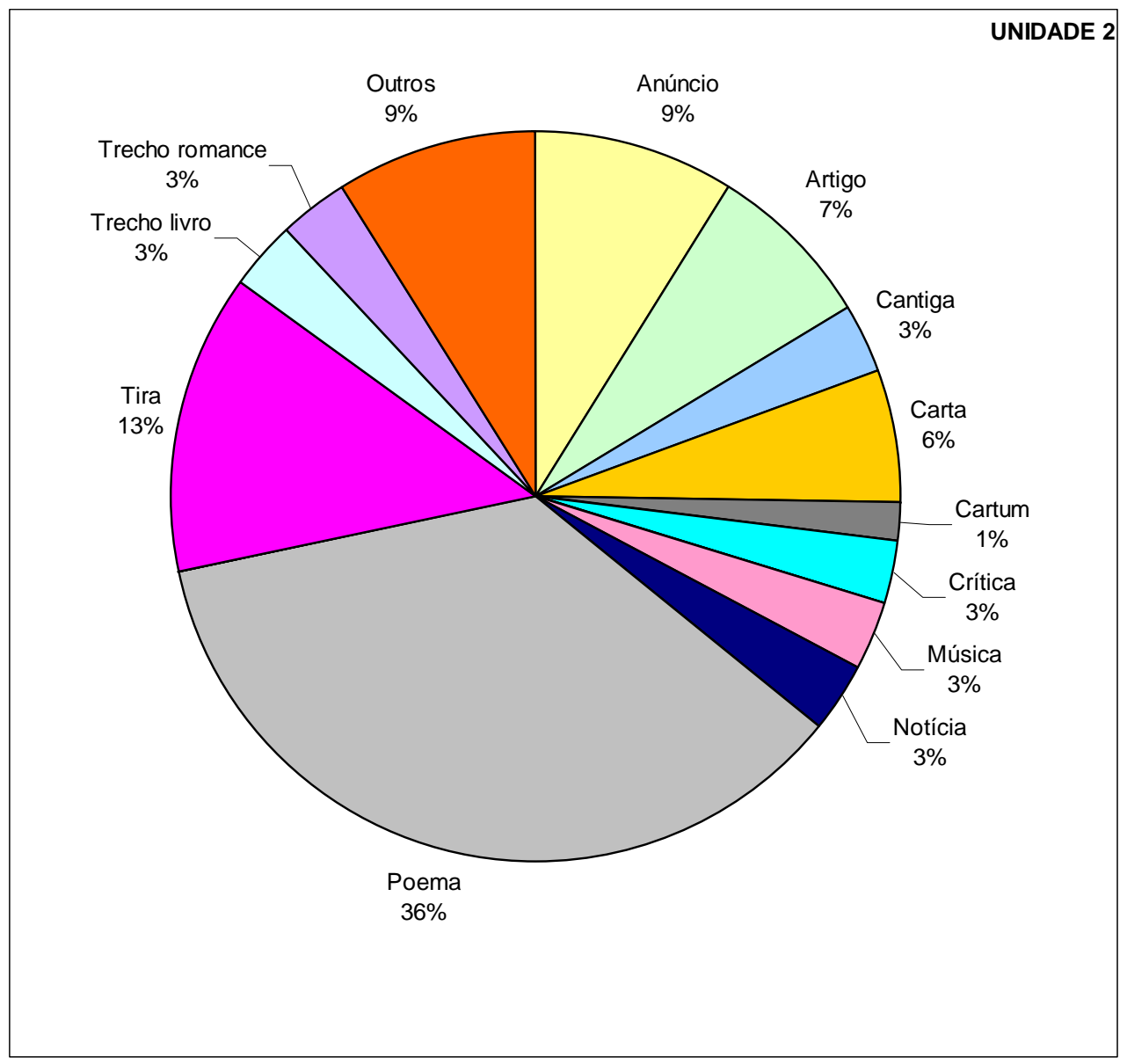

Gráfico 3.18 Gêneros contemplados na unidade 2 


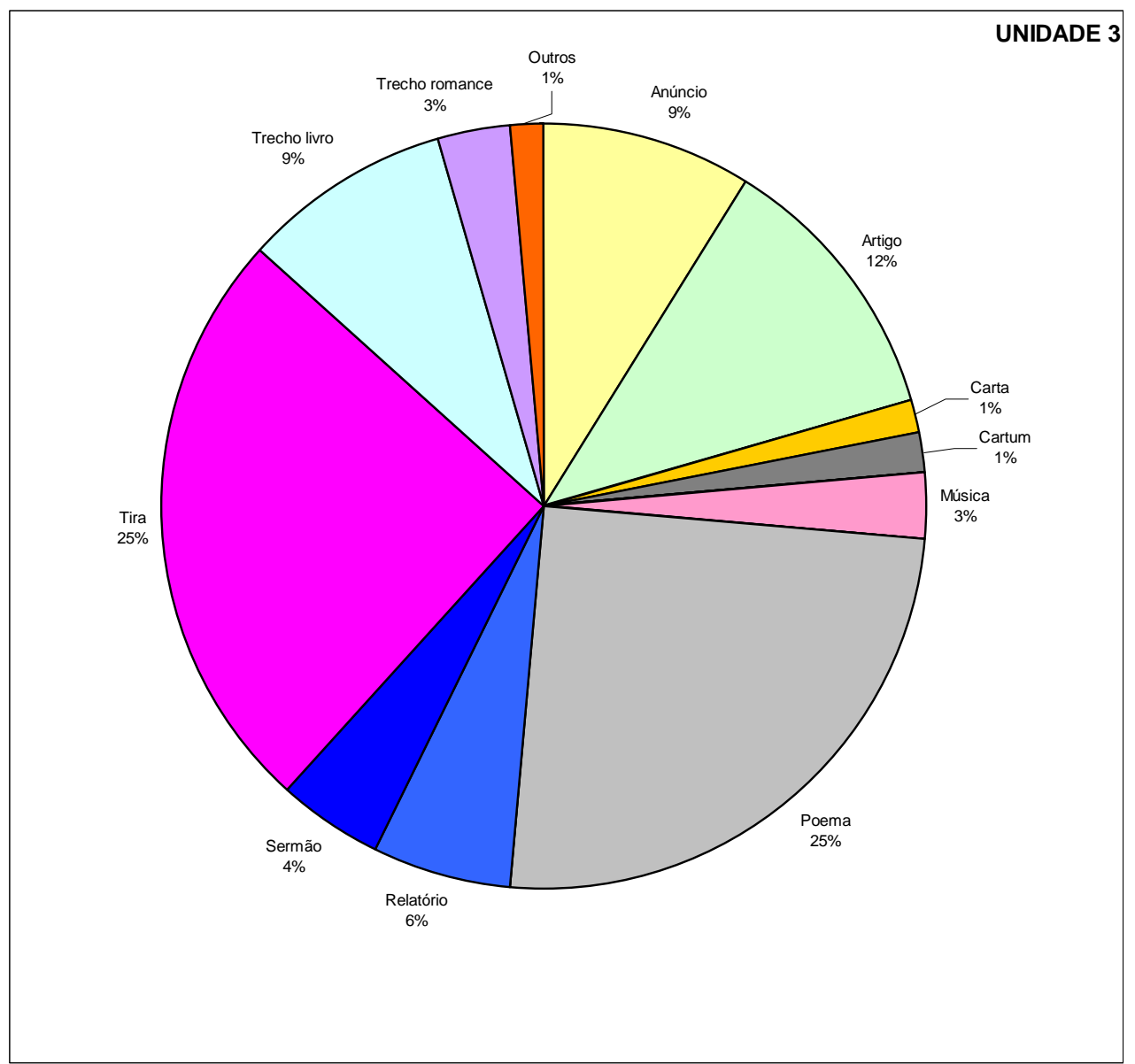

Gráfico 3.19 Gêneros contemplados na unidade 3 


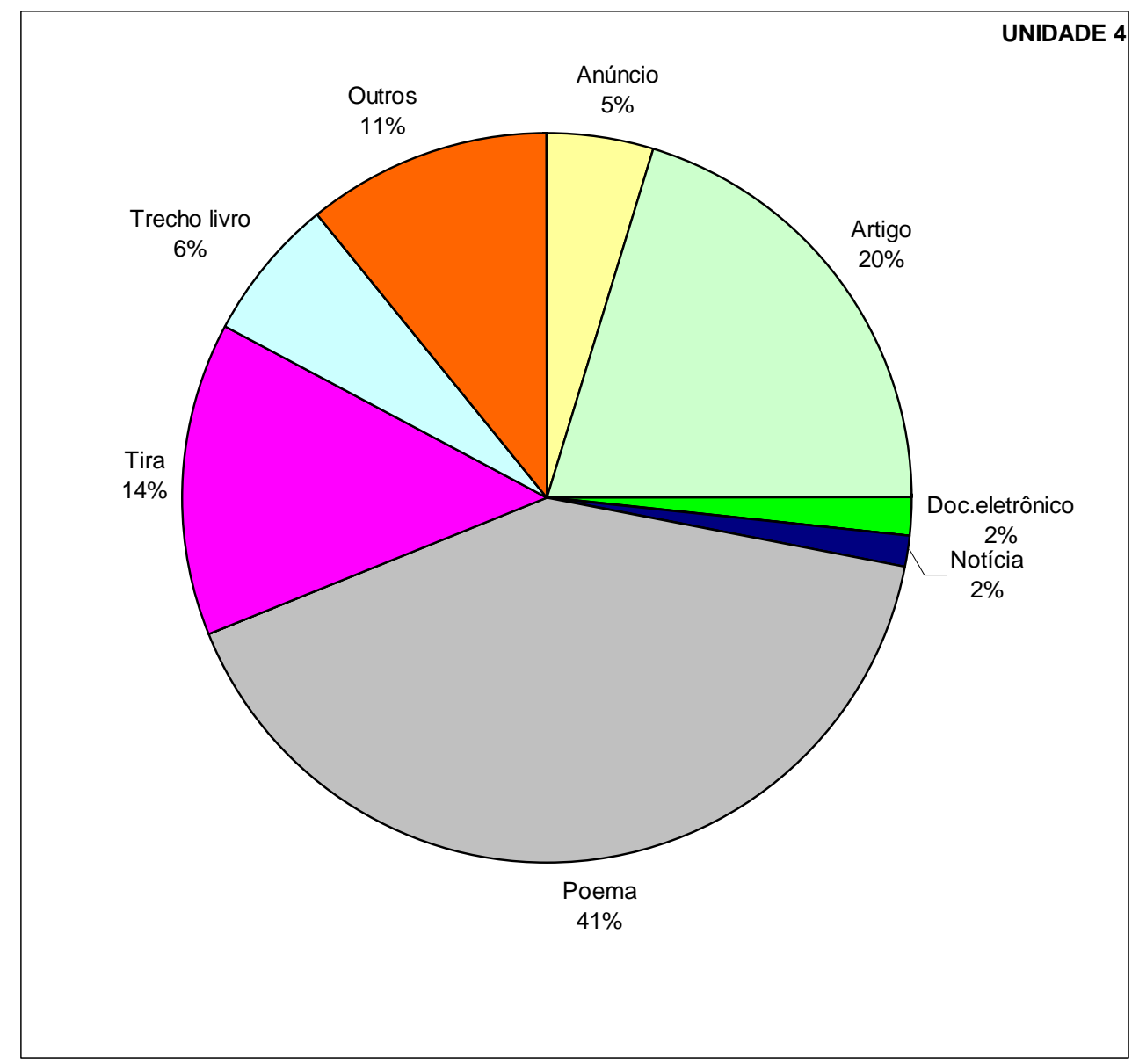

Gráfico 3.20 Gêneros contemplados na unidade 4

Apresentamos, a seguir, um gráfico geral que representa todos os gêneros encontrados nas quatro unidades do livro Português Linguagens. 


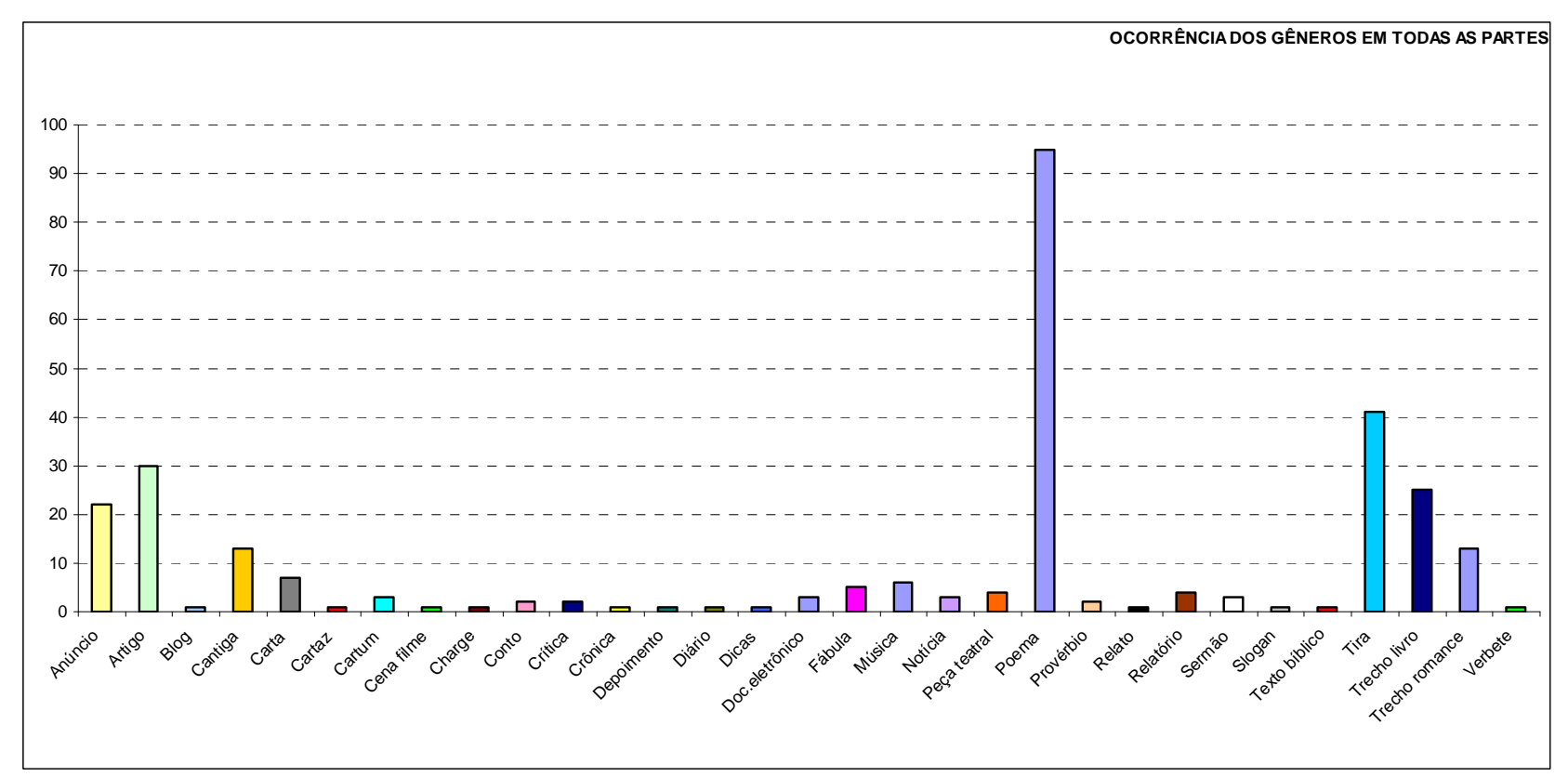

Gráfico 3.21 Gêneros discursivos no livro Português Linguagens

Após conhecermos as ocorrências dos gêneros discursivos nos livros didáticos selecionados para o presente trabalho, constatamos que o gênero discursivo mais estudado nos três livros é o poema. Tal constatação está relacionada ao fato de que os movimentos literários explorados no primeiro ano do Ensino Médio - Trovadorismo, Humanismo, Classicismo, Barroco e Arcadismo trazem como base de estudo o poema.

Passaremos, no próximo capítulo, a análise do corpus dedicada a alguns gêneros discursivos que são trabalhados nos livros didáticos selecionados. 


\section{OS GÊNEROS DISCURSIVOS NO LIVRO DIDÁTICO: Análise do}

\section{corpus}

Como já foi visto no capítulo anterior, os livros didáticos selecionados apresentam uma grande diversidade de gêneros discursivos, como: poesia, tira de quadrinhos, música, artigo, blog, cartum, fábula, notícia etc. Mas a exploração desses textos deve levar o aluno a produzir, reproduzir e desafiar a realidade em que vive, conforme sugere Meurer. Os exercícios propostos para o estudo dos textos devem levar o aluno a perceber aqueles que estão relacionados às situações de comunicação oral e imediata e aqueles que envolvem escrita e estão relacionados às situações mais complexas. Ou ainda, os alunos devem estudar a inter-relação entre os gêneros discursivos primários e secundários, sugerida por Bakhtin. As atividades encontradas nos livros devem relacionar texto e contexto e levar o aluno a perceber a importância das condições de produção dos textos.

Partiremos, a seguir, para uma análise de algumas propostas dos autores dos livros didáticos quanto ao trabalho com os gêneros discursivos. Embora seja uma pequena mostra dos gêneros discursivos estudados nos livros, procuramos escolher atividades relacionadas a gêneros discursivos diferentes em cada um dos livros selecionados.

\subsection{Língua e Literatura}

Selecionamos no livro Língua e Literatura três atividades com os gêneros discursivos: um trecho de romance, uma tira de quadrinhos e um trecho de conversa em sala de bate-papo.

A) Trecho de romance

A atividade abaixo foi destacada da página 24, da Unidade I "Linguagem", que conceitua língua, linguagem, signos, fala, palavra, denotação e conotação.

Para o trecho que segue, os autores propõem as seguintes questões:

2. O trecho seguinte foi extraído do livro Quarto de despejo - diário de uma favelada. Na edição dessa obra, os originais da autora sofreram poucas mudanças. Leia: 


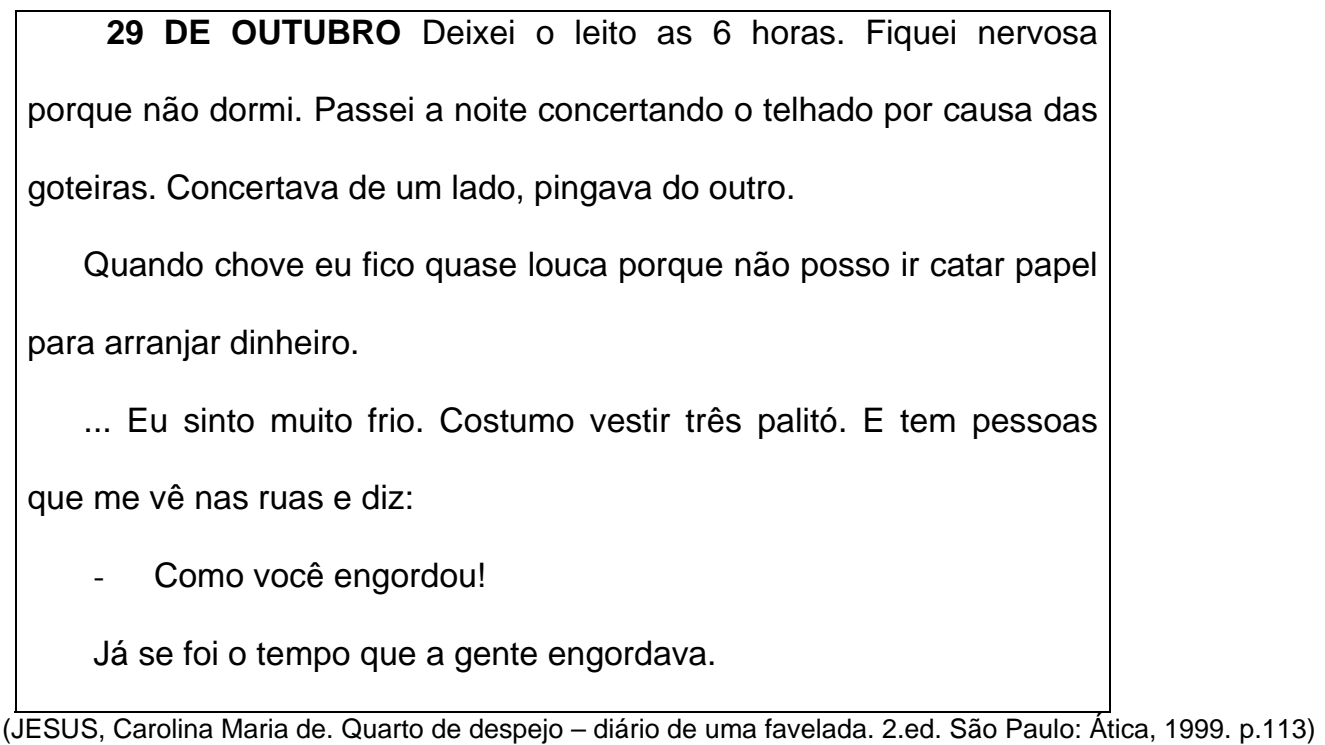

Que infrações à gramática normativa ocorrem no texto?

3. Se os originais da autora, uma mulher com baixo grau de escolaridade, tivessem sido revisados de acordo com a gramática normativa, o que se perderia no livro, na sua opinião? Justifique sua resposta.

O trecho de romance que selecionamos para análise, traz características de dois gêneros discursivos: o gênero romance (embora se trate de um trecho apenas) e o gênero diário, ou seja, o gênero discursivo romance foi constituído a partir da forma/estrutura composicional de um diário, duas fontes de proveitoso trabalho que muito poderiam contribuir para as leituras e produções de textos do aluno do primeiro ano do ensino médio.

Os autores do livro didático optaram por tão somente realizar um estudo da gramática normativa, deixando de lado um trabalho mais rico e proveitoso para a formação do aluno e do cidadão.

B) Tira de quadrinhos

Esta atividade consta da página 81 do livro, na Unidade IV "Gêneros literários":

A maioria das histórias em quadrinhos também se classifica no gênero narrativo: 


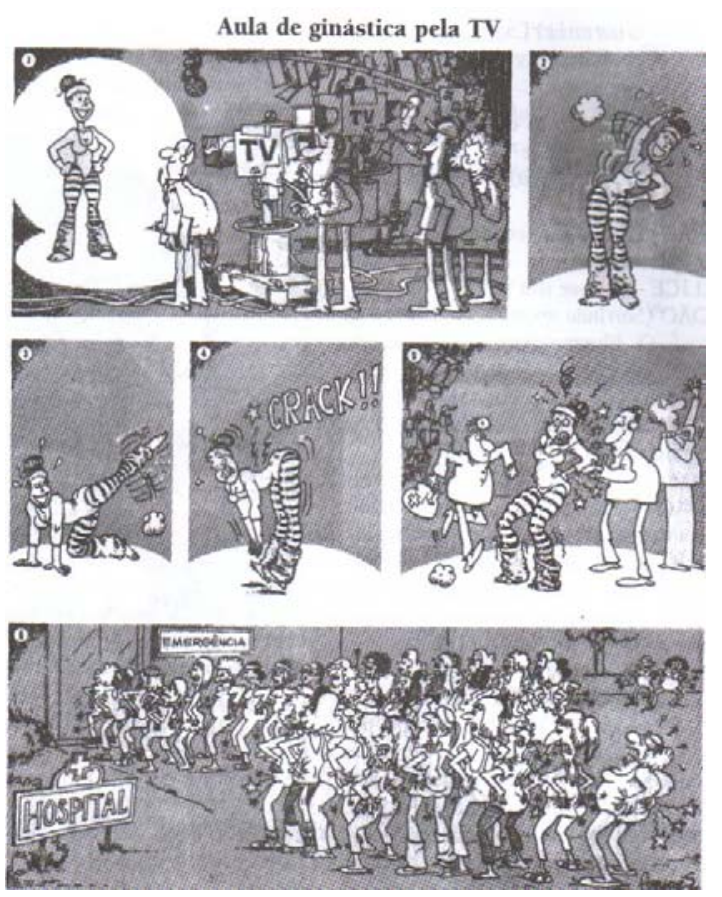

Segue a questão proposta pelos autores do livro didático:

> Recontar oralmente a história em quadrinhos. Lembre-se: a língua falada dispõe de recursos, como a entonação, gesticulação e a expressão fisionômica.

Essa atividade convidou-nos a uma análise porque as tiras de quadrinhos são subsídios valiosos para reconhecermos aspectos da modalidade oral da língua e essa seria uma excelente oportunidade para um minucioso estudo sobre o assunto. A atividade proposta pelos autores do livro não comporta uma abordagem produtiva da oralidade, que consistiria em propor atividades pelas quais se pudesse conceber à modalidade oral como prática textual-discursiva, por exemplo, mostrando que a língua oral possui seus próprios recursos, diferentes da modalidade escrita.

A língua oral e a língua escrita possuem condições de produção que determinam formulações lingüísticas que apresentam aspectos distintos e específicos e para que não ocorram distorções é preciso considerá-los. O esquema a seguir contribui para uma melhor compreensão das condições de produção da oralidade e da escrita: 


\begin{tabular}{|c|c|}
\hline Fala & Escrita \\
\hline -Interação face a face & -Interação à distância (espaço temporal) \\
\hline $\begin{array}{l}\text {-Planejamento simultâneo ou quase } \\
\text { simultâneo }\end{array}$ & -Planejamento anterior à produção \\
\hline -Criação coletiva & -Criação individual \\
\hline -Impossibilidade de apagamento & -Possibilidade de revisão \\
\hline $\begin{array}{l}\text {-Sem condições de consulta a outros } \\
\text { textos }\end{array}$ & -Livre consulta \\
\hline $\begin{array}{l}\text {-A reformulação pode ser promovida } \\
\text { tanto pelo falante como pelo interlocutor }\end{array}$ & $\begin{array}{l}\text {-A reformulação é promovida apenas } \\
\text { pelo escritor }\end{array}$ \\
\hline $\begin{array}{l}\text {-Acesso imediato às reações do } \\
\text { interlocutor }\end{array}$ & -Sem possibilidade de acesso imediato \\
\hline $\begin{array}{l}\text {-O falante pode processar o texto, } \\
\text { redirecionando-o a partir das reações } \\
\text { do interlocutor }\end{array}$ & $\begin{array}{l}\text {-O escritor pode processar o texto a } \\
\text { partir das possíveis reações do leitor }\end{array}$ \\
\hline $\begin{array}{l}\text {-O texto mostra todo o seu processo de } \\
\text { criação }\end{array}$ & $\begin{array}{l}\text {-O texto tende a esconder o seu } \\
\text { processo de criação, mostrando apenas } \\
\text { o resultado }\end{array}$ \\
\hline
\end{tabular}

Fonte: Fávero, Andrade e Aquino (1999, p.74)

\section{Quadro 4.1 Condições de produção da oralidade e escrita}

A atividade proposta pelos autores do livro didático, se tivesse explorado tais condições de produção, poderia levar o aluno a aperfeiçoar suas habilidades comunicativas. A atividade proposta sugerida pelos autores limita-se apenas à pratica da leitura oral de um texto.

C) Bate-papo

A terceira atividade que selecionamos encontra-se na Unidade IV do livro, na página 140. O título do capítulo é "Trovadorismo" e tem como texto de abertura do capítulo "Computador: cupido eletrônico", veiculado no jornal O Estado de S.Paulo.

Segue a atividade que selecionamos para análise: 
5. O texto "Cupido eletrônico" trata de namoros pelo computador. Transcrevemos um trecho de uma conversa ocorrida numa sala de bate-papo em 13/10/99. Acompanhe principalmente o diálogo entre Tiago e Sedutora Sp:

(17:46:12) TIAGO fala para Sedutora SP: Eu sou moreno, olhos castanhos e cabelo castanho escuro, e tenho $19^{\text {a }}$, e vc o que gosta de fazer?

(17:46:19) Sedutora Sp fala para EDU: podemos afinal um papo sempre é bom e todos nos gostamos.

(17:46:20) É o amor!: entra na sala...

(17:46:43) MEL@NNI: entra na sala...

(17:46:59) Sedutora Sp fala para TIAGO: Eu gosto de estudar, passear e viajar e vc?

(17:47:43) Sedutora fala para EDU: aqui está super gostoso e quente!!

(17:47:46) rinaldo fala para Helen: oi, tudo bem??

(17:48:16) Sedutora SP fala para TIAGO: de vc tecla?

(17:48:37) TIAGO fala para Sedutora SP: idem, mas ñ tenho tempo, pois trabalho e não sobra tempo, só no final de semana, gostaria de conhecer

(17:48:45) Sedutora Sp fala para TIAGO: Que bairro eu estou super curiosa para saber.

(17:48:58) g@atinho 69 reservadamente grita com TODOS: alguma gata quer tc

(17:49:25) noivo: tem alguma japonesa??

(17:50:12) Sedutora Sp fala para TIAGO: Eu adoraria te conhecer mas vc acabou de dizer que não vai Ter tempo nos finais de semana os finais de semana é mais apropriado para um casal de conhecer.

(17:50:15) Principe dos sonhos: Boa tarde! Alguma princesa de Sampa afim de um tc???

(17:50:33) Icarus: entra na sala...

(17:51:03) Sedutora Sp fala para TIAGO: Qual é a sua profissão?

(17:52:43) TIAGO fala para Sedutora Sp: auxiliar de escritório, e pelas suas características que vc citou vc deve ser bonita, estou começando a gostar de vc

(17:54:20) Sedutora Sp fala para TIAGO: Muito obrigada pelas qualidades que vc me deu eu também estou começando a gostar de vc.

(17:54:53) TIAGO fala para Sedutora Sp: que tal nós marcarmos um encontro?

(UNIVERSO ON LINE. Sala 3 - namoro no escuro)

\section{O autor propõe como questão para o texto o seguinte exercício:}

Compare a linguagem desse texto com a linguagem da cantiga e identifique traços de formalidade e informalidade em uma e outra. 
O bate-papo é um gênero discursivo produzido por meio de um suporte material eletrônico (a internet). É uma forma moderna de as pessoas se comunicarem e faz parte do universo do adolescente que freqüenta o primeiro ano do ensino médio. Segundo Hilgert (2000, p. 17):

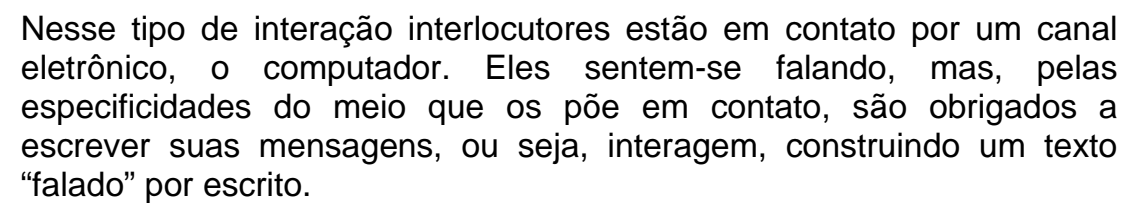

O bate-papo é usado pelo adolescente por duas razões básicas: proporciona uma interação pessoal, tem um caráter social e uma atmosfera predominantemente recreativa. O reconhecimento de tais características e estratégias poderiam auxiliar o aluno na adequação desse gênero discursivo àquela situação de comunicação que lhe é permitida. Mas, o texto somente serviu para a comparação entre a formalidade e informalidade entre o bate-papo e uma cantiga trovadoresca.

\subsection{Língua, Literatura e Produção de Textos}

Seguem agora três exemplos de atividades propostas pelo autor do livro didático Língua, Literatura e Produção de Textos.

a) Entrevista

A primeira atividade que selecionamos encontra-se no capítulo 2, dedicado ao estudo dos "Processo de comunicação e seus elementos", Parte 2, na página 150. Temos, abaixo, um texto de entrevista de Nilma Raquel com Felipe Dylon, publicada em janeiro de 2004.

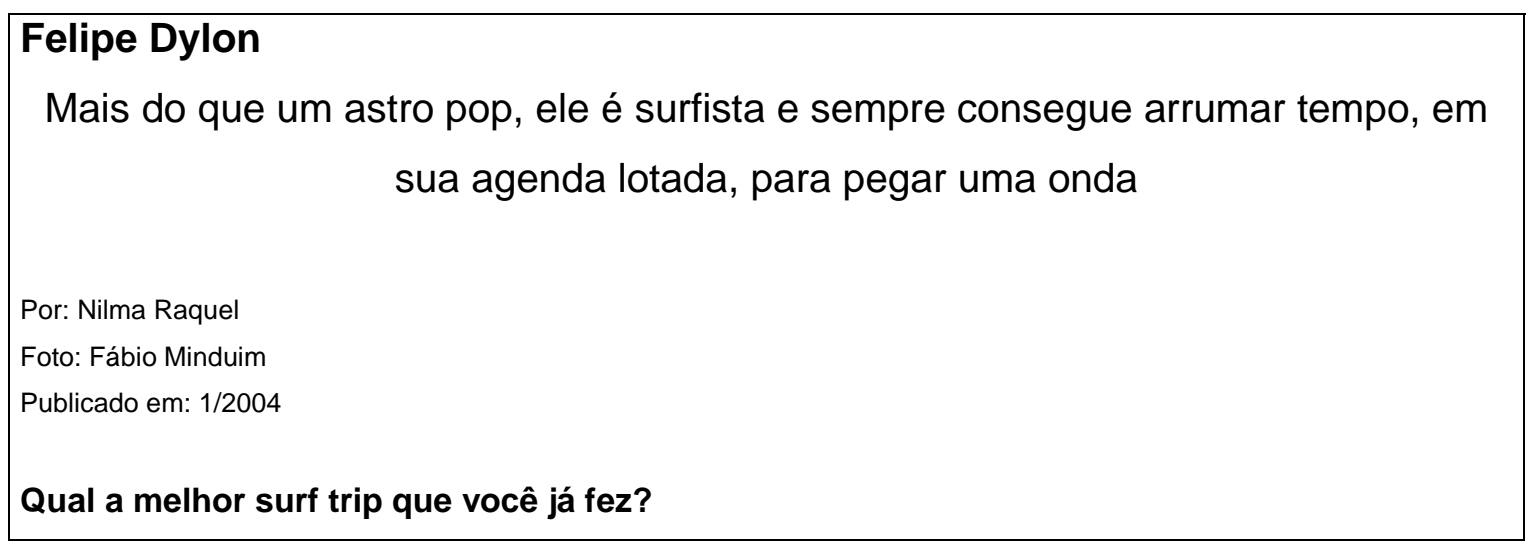


Tive oportunidade de viajar com meu pai para a Califórnia e peguei boas ondas lá, apesar de a água ser congelante. Em seguida a gente foi ao Hawai, tive grande prazer de estar naquela terra, lugar muito bonito, uma energia boa pra caramba, sem contar as ondas perfeitas. A surf trip da minha vida sem dúvida foi para o Hawai.

\section{Qual a surf trip dos seus sonhos?}

Pô, tem vários lugares que eu tenho vontade de conhecer. Quero ir à Indonésia, um lugar que vejo em filmes e fico louco. Depois dá até tédio pegar essas ondas aqui no Brasil. Tenho vontade de conhecer também a Austrália, tem um grande amigo meu que mora lá e diz que pega altas ondas com grande freqüência. Tenho vontade de conhecer muitos lugares ainda, até umas direitas lá na África do Sul, se Deus quiser, eu vou pegar.

\section{Como você se vê daqui a dez anos?}

Acho que estarei fazendo mais shows, com uma quantidade maior de gente gostando do meu trabalho, e eu continuarei o mesmo moleque de sempre, surfista, que gosta da natureza, do mar e de curtir como qualquer outra pessoa.

http://www.2.uol.com.br/fluir/fluir_girls/04_04_27_felipe_dylon.shtml

\section{Para a entrevista acima, o autor propõe os exercícios que seguem:}

1. Observe os pronomes pessoais de primeira, segunda e terceira pessoas que aparecem ao longo do texto (eu/você/ele). Quais são seus referentes?

2. Releia a resposta à primeira pergunta da entrevista e comente:

a) a referência extratextual dos tempos verbais empregados;

b) o tipo de referenciação dos circunstanciais lá e naquela terra.

3. Após uma nova leitura da resposta à segunda pergunta:

a) evidencie algumas "palavrinhas" argumentativas, reescreva o parágrafo sem elas e compare-o com a versão original;

b) no trecho "Depois dá até tédio pegar essas ondas aqui do Brasil", comente a relação entre as palavras destacadas e o valor semântico do demonstrativo;

c) explique o tipo de referenciação do advérbio lá, que aparece duas vezes, comparando os casos.

4. O referente do advérbio daqui da última pergunta é textual ou situacional/ Justifique sua resposta. 
No capítulo em que se encontra essa atividade, o autor aborda o processo de comunicação, as competências dos participantes e, a atividade que estamos analisando, aparece no subtítulo "Recursos textuais para montagem da mensagem". O autor apresenta textos teóricos sobre o que é intencionalidade, referência situacional e referência textual, mas não cita os teóricos que estudam referenciação.

As quatro questões estão relacionadas à referenciação e, a partir das teorias conhecidas no capítulo, podem levar o aluno a perceber que "o dizer orienta-se sempre para algo que não é um dizer" e que "é a esta orientação que se denomina referência" (KOCK e FÁVERO, 1984, p.11). A referenciação é importantíssima para o entendimento, reconhecimento e adequação dos gêneros do discurso.

A entrevista é um importante gênero discursivo. A entrevista aproxima-se da conversação e, apesar de ser construída visando a um público determinado, segue as regras do diálogo cotidiano. "Neste tipo de interação, há certos elementos condicionantes que são próprios da comunicação espontânea", comenta Andrade (2001, p. 99). Falantes de todas as classes sociais usam, muitas vezes, a norma não-padrão nesse tipo de evento. O livro didático não explica nem explora as características desse tipo de interação, assim como não aponta as características desse gênero discursivo: a entrevista escrita.

B) Tira de quadrinhos

Essa atividade encontra-se no Capítulo 3 "Gêneros e tipos textuais no cotidiano", p.162, parte 2 do livro. Esse capítulo diferencia gêneros textuais de tipos textuais, relaciona os tipos textuais e sua gramática e descreve as seqüências textuais. Aqui também não são apresentadas citações de Bakhtin e Bronckart, teóricos que se dedicaram ao assunto
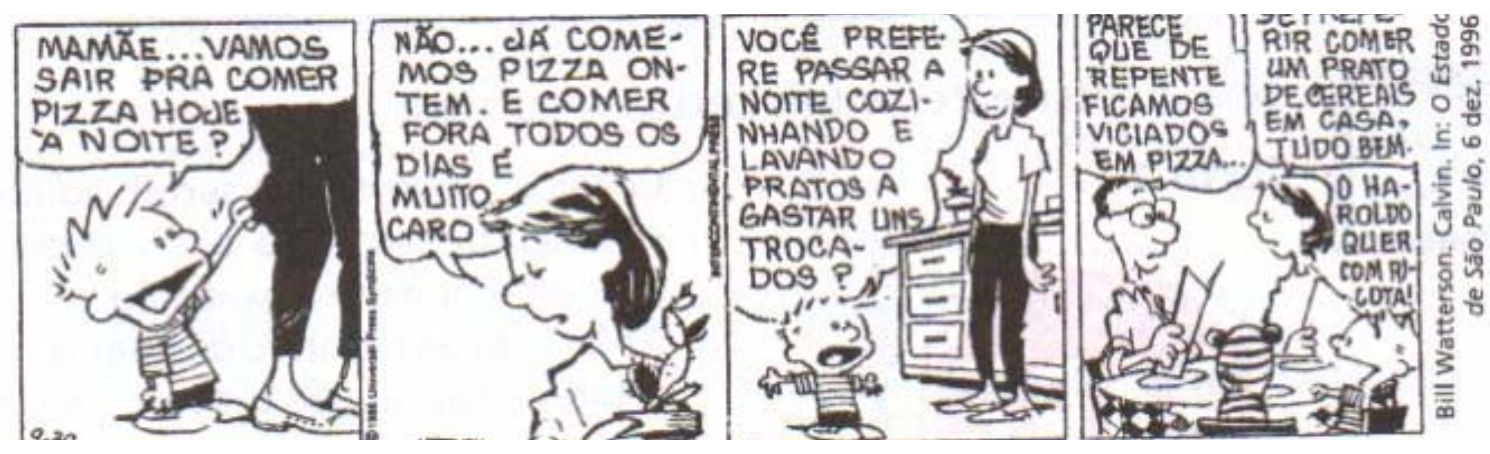
As questões propostas pelo autor, são:

a) Qual é o gênero textual e quais são as características que permitem identificá-lo?

b) Pensando no texto como um todo, qual é o tipo textual que predomina? Justifique sua resposta.

c) Pensando nas falas, qual é a seqüência textual que predomina?

d) Observe com atenção o primeiro quadrinho: Calvin está fazendo uma pergunta, mas sua intenção não é a de obter informação. Calvin faz mais uma pergunta a sua mãe. Qual é a sua intenção? Como você classificaria essa seqüência?

e) No terceiro quadrinho, Calvin faz mais uma pergunta a sua mãe. Qual é a sua intenção? Como você classificaria essa sequência?

f) Observando o quarto quadrinho, responda: Calvin conseguiu atingir suas intenções? Explique.

As questões a, b e c ficam bastante no plano das teorias sobre gênero, tipo e seqüências já as questões de d a f procuram relacionar as teorias à situação dos quadrinhos, o que leva o aluno a entender a intencionalidade e a seqüência.

Apesar de os gêneros discursivos envolverem o formato, a estrutura lingüística, o assunto e estarem relacionados às práticas sociais, o autor limita-se a trabalhar as intenções e as seqüências.

A tira envolve a estrutura dialogal e esta poderia ser uma possibilidade de trabalho a ser sugerida pelo autor do livro didático. "A necessidade de se estudar o par adjacente (pergunta-resposta [...]) deve-se ao fato de ser elemento básico da interação." (FÁVERO; ANDRADE; AQUINO, 1999, p. 49)

Além de elemento básico da interação, o par pergunta-resposta organiza a conversação, controla o encadeamento de ações e pode, inclusive, introduzir o tópico discursivo, como é o caso do primeiro quadrinho em que Calvin pergunta à mãe: "Mamãe... vamos comer pizza hoje à noite?". Já no terceiro quadrinho, a pergunta de Calvin não serve somente para introduzir um tópico discursivo, mas, nesse caso, Calvin utiliza uma pergunta no sentido de persuadir sua mãe a fazer o que ele deseja. O autor do livro Língua, Literatura e Produção de Textos poderia ter aproveitado a atividade para estudar a estrutura e estratégias relativas ao par adjacente pergunta-resposta. 
C) Cartum

A terceira atividade selecionada no Língua, Literatura e Produção de Textos é um cartum da página 237. O capítulo é o 9 "Recursos estilísticos - a sonoridade das palavras", Parte 2 do livro didático.

Texto para as questões de 7 a 9.

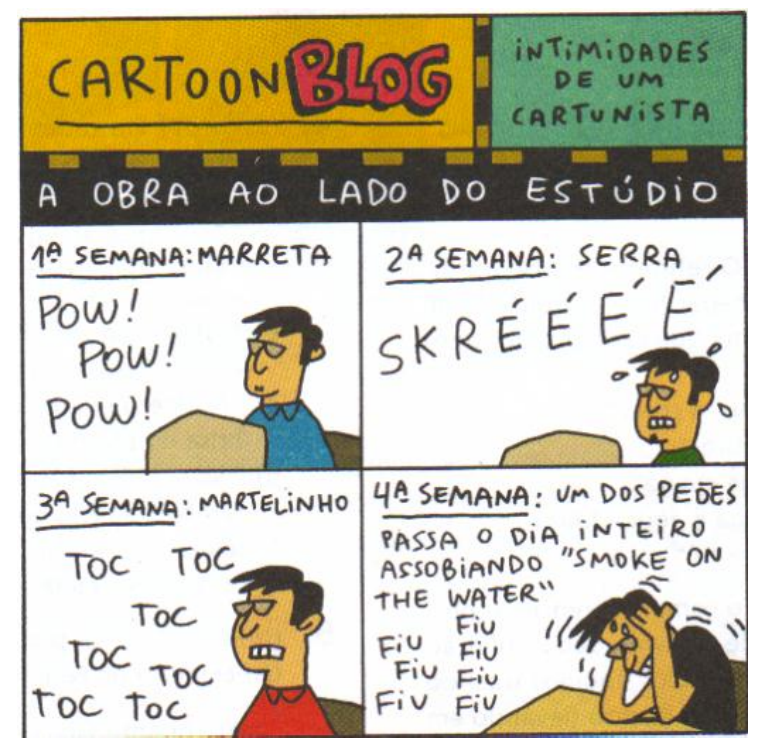

Questões propostas pelo autor:

7. Qual é o recurso sonoro utilizado no cartum para obter humor?

8. A seqüência temporal acompanhada pelos sons da obra que atrapalham a vida do cartunista evidenciam uma gradação crescente. Justifique.

9. Tente imaginar outros sons da obra do estúdio do cartunista que pudessem atrapalhar a tranqüilidade dele e represente-os por meio de onomatopéias.

As questões propostas pelo autor trabalham somente os sons e a sonoridade. Nada é explorado quanto ao tema, forma composicional nem ao estilo e outras características do gênero discursivo cartum.

Apesar de não ser a proposta do capítulo trabalhar características de algum gênero discursivo, logo abaixo das questões o autor sugere uma produção de texto ao aluno e inicia a proposta com o seguinte enunciado: "Cartunista é o nome dado ao profissional que desenha e escreve cartuns, charges, desenhos animados ou tiras cômicas. E é nesses gêneros que encontramos a onomatopéia como um dos recursos recorrentes," e prossegue: "Montem pequenas equipes de 'cartunistas' e preparem um cartum”. Ou seja, além de descrever as 
características do cartum, o autor propõe uma produção do gênero discursivo apresentado. Consideramos relevante tal iniciativa, pois o conhecimento $\mathrm{e}$ adequação dos gêneros discursivos muito pode contribuir para o crescimento intelectual do aluno do primeiro ano do ensino médio.

\subsection{Português Linguagens}

Selecionamos no Português Linguagens um anúncio, uma letra de música e uma carta pessoal.
A) Anúncio
O anúncio selecionado aparece na página 23 do Capítulo 1 "Linguagem, comunicação e interação":

\begin{tabular}{|l|}
\hline Olá, Papai Noel :) \\
Em primeiro lugar já está mais do que na hora \\
de vc ter um e-mail. Não existe nada mais antigo \\
que mandar uma carta. Mas, vamos lá: estou \\
precisando de um upgrade no meu home-office. \\
Por isso, neste Natal eu quero um OZ Gradiente. \\
Talvez uma pessoa que nem website tem não \\
saiba o que é isso. OZ é DVD, TV, CD, MP3, \\
FM, internet e computador ao mesmo tempo. Na \\
verdade o senhor devia me agradecer. Imagine se eu \\
tivesse pedido tudo isso separado, o peso \\
Que seria no seu saco. Tks,........................................
\end{tabular}

(Veja, 18/12/2002.)

As questões relativas ao anúncio são as seguintes:

1. O anúncio tem por finalidade, evidentemente, vender um determinado tipo de produto e, para isso, lança mão de um conjunto de estratégias. Responda:

a) O anúncio apresenta uma estrutura semelhante à de um tipo de texto muito usado em correspondências. Qual é esse tipo de texto?

b) Quem, supostamente, é o autor desse texto : criança, adolescente ou adulto? Por quê? 
c) Sabendo-se que o anúncio foi publicado no mês de dezembro e levando-se em conta o destinatário da carta, quem supostamente são os interlocutores do anúncio?

d) Na sua opinião, as estratégias utilizadas pelo anunciante são eficientes para que o anúncio atinja seu objetivo? Por quê?

2. A sintonia da linguagem do texto revela algumas informações sobre as características do autor.

a) Qual o significado dos seguintes sinais, palavras e expressões?

\begin{tabular}{|llllll|}
\hline$:)$ & e-mail & upgrade & home-office & website & MP3 tks \\
\hline
\end{tabular}

b) O que o domínio dessas palavras e expressões revela sobre o autor do texto?

3. Conclua: Qual a importância da variedade lingüística escolhida na construção do anúncio, tendo em vista a finalidade deste?

As questões 1 e 2 trabalham de maneira satisfatória os aspectos do gênero discursivo anúncio e do gênero discursivo carta. Levam o aluno a perceber as estratégias usadas no anúncio e a interação que ocorre entre autor e destinatário da carta, locutor e interlocutor da mensagem. A terceira questão trabalha a variedade lingüística utilizada que, além de tornar o anúncio mais informal, define o público alvo pretendido pelo anunciante.

B) Letra de música

Capítulo 4 "Introdução aos gêneros do discurso", página 51:

Leia a letra da canção "Dois rios", de Samuel Rosa, Lô Borges e Nando Reis. Se possível, ouça a composição que se encontra no CD Cosmotron, do Grupo Skank, e responda às questões de 3 a 6.

\begin{tabular}{|lll|}
\hline $\begin{array}{l}\text { O céu está no chão } \\
\text { O céu não cai do alto } \\
\text { É o claro, é a escuridão }\end{array}$ & $\begin{array}{l}\text { Dois rios } \\
\text { E sol se pós se pôr } \\
\text { O sol renasce no Japão }\end{array}$ & $\begin{array}{l}\text { Que os braços sentem } \\
\text { E os olhos vêem } \\
\text { Que os lábios beijam } \\
\text { Dois rios inteiros } \\
\text { Sem direção }\end{array}$ \\
$\begin{array}{lll}\text { O céu que toca o chão } \\
\text { É que vai no alto }\end{array}$ & $\begin{array}{l}\text { Eu vi também } \\
\text { Dois lados deram as mãos poder entender }\end{array}$ & Na voz a vida ouvi dizer \\
Como eu fiz também & E o meu lugar é esse \\
Só pra poder conhecer & E os olhos vêem & Ao lado seu, no corpo inteiro \\
\hline
\end{tabular}




\begin{tabular}{|llr|}
\hline O que a voz da vida vem dizer & $\begin{array}{l}\text { Que os lábios sejam } \\
\text { Dois rios inteiros }\end{array}$ & O dia e a noite as quatro estações \\
O sol é o pé e a mão & Sem direção & \\
O sol é a mãe e o pai & & \\
Dissolve a escuridão & & \\
\end{tabular}

3. A letra da canção apresenta várias relações binárias, isto é, pares de elementos que se aproximam ou se opõem. Identifique no texto:

a) elementos que estejam em oposição;

b) elementos que formem um tipo de relação diferente.

4. A linguagem da canção apresenta bastante sonoridade. É o caso, por exemplo, da sonoridade criada pela repetição do som /s/ (lê-se cê) das palavras céu, só, sol, dissolve, se, após, renasce, braços e sentem, entre outras. Com base na $5^{a}$ e na $6^{a}$ estrofes, identifique outras repetições sonoras.

5. A letra da canção faz uso da conotação em diferentes situações. É o caso, por exemplo, da caracterização do sol feita na $4^{\mathrm{a}}$ e $5^{\mathrm{a}}$ estrofes. Dê uma interpretação coerente a esses versos.

6. A expressão "dois rios" também foi empregada conotativamente e constitui um dos elementos básicos para a interpretação da letra.

a) O que ou quem representa os dois rios?

b) A relação existente entre os dois rios pode ser compreendida a partir das outras relações binárias mencionadas na canção, como céu e chão, claro e escuridão? Explique por quê.

A seleção da atividade, acima, fez-se pela possibilidade de observarmos que, apesar de pertencer a um capítulo introdutório sobre os gêneros discursivos, as questões propostas estão somente relacionadas à denotação, conotação e relações binárias. Os autores do livro não exploram nem o tema, nem a forma composicional, nem o estilo de texto que tanto poderiam contribuir para 0 entendimento do aluno quanto ao fato de condições de produção de um tipo de texto com o qual ele se depara em diversas situações de sua vida. O autor sequer explora o fato de tratar-se de música de um conjunto jovem que atinge o públicoalvo do livro didático em questão. O que seria bastante recomendado. Trata-se de uma música do Skank que é um conjunto bastante ouvido pelos alunos do ensino médio, principalmente do primeiro ano. 
C) A carta pessoal

O terceiro texto foi extraído do capítulo 17 "Trabalhando o gênero", páginas 163 e 164.

Campinas, 10 de setembro de 2005.

Querida Micha

Quanto tempo não te escrevo... Mexendo na minha gaveta bagunçada, encontrei os papéis de carta com cheirinho de maçã verde (aqueles que compramos juntas naquelas férias radicais de janeiro, lembra? ) e, de repente, me bateu aquela saudade de você. E por falar em férias, estou louca por umas. A vida não está nada fácil pra mim, amiga, pois estou estudando o dia inteiro pra passar na faculdade pública no final do ano. Alguns até já estão me chamando de CDF, imagine eu uma CDF! Fora o apelido, eu continuo a mesma, curiosa, cheia de perguntas e totalmente indecisa nas respostas, como sempre. Eu não consigo nem decidir o nome do peixe que ganhei há dois meses de minha mãe, muito menos se namoro ou não aquele gato da rua de cima. Ele é tão bonitinho, inteligente, educado, legal, mas é também meio antipático, convencido demais para uma garota tão especial como eu, você não acha?

Gostei demais das novidades da sua última carta, do seu emprego no shopping... Fico com pena de você ter que ralar nessa idade, pois isso te rouba tempo dos estudos. Mas tenho certeza que você chegará lá, na realização de seus sonhos, pois para isso é preciso ter garra e isso você tem de montão... Bom, da última vez que nos vimos suas unhas estavam bem compridas (risos)

Não pare de me escrever! Você não sabe como sinto falta dos velhos tempos de fofocar em cima da "nossa" árvore, ou da revolta de seu irmão quando a gente invadia o quarto dele pra dançar com o som no último! Aproveita e diga pro nerd do seu irmão me escrever, pois eu só mudei de endereço, não de amigos.

Não se esqueça de mim, tá? Me escreva.

Com carinho,

Pity

PS.: Minhas irmãs te mandam um beijo. Ah! Sabe onde meu irmão está neste momento? No Japão! Conto sobre isso na próxima, tá? Bye, bye!

(Suelen Cristina Gennari - 17 anos) 
Os cinco exercícios que seguem, são propostos pelo autor do livro didático:

1. A carta é um gênero textual que costuma apresentar uma estrutura padrão, composta de local e data, vocativo (nome da pessoa a quem se dirige a carta), texto e assinatura.

a) A carta em estudo apresenta esses elementos em sua estrutura?

b) O vocativo pode conter apenas o nome do destinatário ou vir acompanhado de palavras de cortesia. Junto ao nome da pessoa a quem Pity escreve a carta, foi empregada a palavra querida.

O que esse tratamento revela quanto ao relacionamento das interlocutoras?

c) Qual é o assunto da carta?

2. Depois da assinatura, há um P.S., abreviatura da expressão latina post scriptum, que significa "depois de escrito".

a) Qual é a finalidade do P.S.?

b) Qual foi o objetivo de Pity ao incluir um P.S. em sua carta?

3. Observe a linguagem empregada nestes trechos da carta:

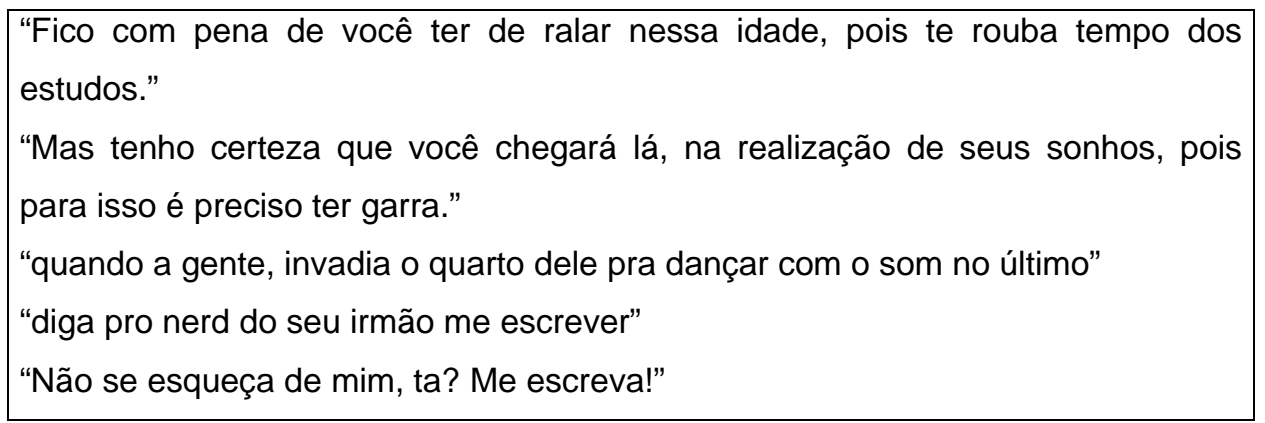

a) Que elementos (palavras, expressões, construções) desses trechos fogem à variedade padrão escrita e formal da língua portuguesa?

b) A linguagem empregada na carta em estudo é formal ou informal? Levante hipóteses: O que justifica o uso desse tipo de linguagem na carta?

4. Observe as formas verbais empregadas na carta em estudo.

a) Que tempos verbais predominam?

b) A que fatos se referem os verbos no pretérito?

c) Nas frases:

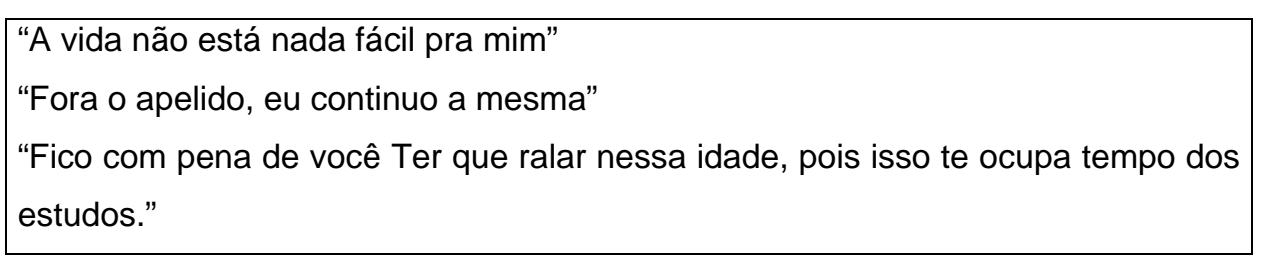

Com que finalidade os verbos foram empregados no presente do indicativo?

- Para enunciar um fato atual, isto é, que ocorre no momento em que se fala. 
- Para expressar ações habituais, ainda que algumas delas não estejam ocorrendo no momento em que se fala

- Para dar vivacidade a fatos ocorridos no passado (presente histórico ou narrativo)

- Para indicar um fato futuro, porém próximo.

5. Reúna-se com seus colegas de grupo e, juntos, concluam: Quais as características da carta pessoal?

Além das descrições que aparecem nos exercícios, os autores do livro optaram por não trazer teoria sobre as características da carta pessoal, exceto em um pequeno boxe que aparece na página 164 intitulado de "Sobre o vocativo e a assinatura" em que explica: "Na carta pessoal, o vocativo pode ser seguido de dois-pontos, de vírgula ou não conter pontuação. A assinatura do remetente é normalmente manuscrita, sem o sobrenome." Há também, na mesma página, um boxe que explica a maneira de se preencher o envelope.

A questões 1 e 2 trabalham a estrutura do gênero carta. A terceira, trata da linguagem empregada na carta de Pity. Aqui parece que os autores do livro vão um pouco além no estudo do gênero, pois fazem o aluno perceber que a carta pessoal utiliza-se da linguagem informal, mas não citam que isso a aproxima da interação oral, podendo apresentar marcas de oralidade. A questão 4 questiona as formas verbais utilizadas e a 5 , leva o aluno a concluir as características da carta pessoal.

As questões trabalham a forma composicional do gênero carta, chamam a atenção do aluno para o estilo, variedade e linguagem utilizadas, mas nenhuma questão leva o aluno a perceber as características da seqüência narrativa, para concluir que esse texto pertence ao gênero epistolar (carta) e que se caracteriza por ser um texto com seqüências narrativas que também apresenta seqüências descritivas, comentários etc.

Na letra a da questão 3, solicita-se ao aluno identificar quais trechos fogem à variedade padrão escrita e formal, apesar disso, os autores não comentam o fato de o uso de tal linguagem estar relacionado à aproximação do gênero carta à conversação cotidiana/língua oral. Isso nos leva a observar que a reclamação de 
Marcuschi (2003) quanto à exploração da língua oral no livro didático é cabível e relevante.

Outro ponto que também não discutido é que a carta traz alguns marcadores como 'pois' e 'mas'. Esses importantes elementos de organização interna do texto não dão margem a nenhum tipo de estudo por parte dos autores do livro.

O 'mas', por exemplo, aparece 2 vezes no texto da carta. Segundo Urbano (1999, p.216), "este marcador é um dos mais férteis em termos de matizes funcionais" , acrescenta que, o 'mas' não só combina o seu traço seqüenciador com o de orientador, mas também seu caráter bidirecional; seu caráter de operador argumentativo e seu caráter de forte orientador interacional. $O$ reconhecimento dessas combinações poderia levar o aluno a compreender e aprender a utilizar melhor os gêneros discursivos em favor de uma comunicação mais efetiva.

O que vemos com muito bons olhos é o fato de, após os exercícios, o aluno ser convidado a produzir três cartas, enviar pelo correio e aguardar a resposta. É sugerida também a leitura de alguns livros que envolvem cartas e apresentado um texto do trecho de um filme em que uma escritora escreve uma carta.

A partir da análise de algumas propostas de atividades nos três livros didáticos selecionados, observamos que a diversidade de gêneros discursivos que são apresentados pelos autores dos livros é grande, mas que um trabalho adequado com esses mesmos gêneros discursivos está longe de ser uma realidade e de atender aos $\mathrm{PCN}$.

O livro que menos trabalha os gêneros discursivos de maneira apropriada é o Língua e Literatura, apesar de informar que está de acordo com as Diretrizes Curriculares Nacionais para o Ensino Médio. O livro Língua, Literatura e Produção de Textos, apesar de não constar do Catálogo do PNLEM, traz algumas questões relevantes sobre os gêneros discursivos. O Português Linguagens faz juz à escolha dos selecionadores do Programa Nacional do Livro didático do Ensino Médio e traz, em grande parte, exercícios que fazem um trabalho que atende às 
exigências da educação e às necessidades do aluno do primeiro ano do Ensino Médio. 


\section{CONSIDERAÇÕES FINAIS}

Por meio do presente trabalho, é possível observar que muitas são as possibilidades de classificações, divisões e agrupamentos dos gêneros discursivos, assim como muitas são as nomenclaturas possíveis para seu estudo, mas é inquestionável que eles são imprescindíveis aos aprendizes, tanto para despertar-Ihes a análise crítica como a auxiliá-los na produção e reprodução da realidade social na qual vivem e dentro da qual vão construindo suas próprias narrativas pessoais. No primeiro capítulo, averiguamos a pluralidade de definições que os gêneros discursivos receberam, apresentando as teorias de Bakhtin, Bronckart, Brandão e outros, assim como a abordagem que os gêneros discursivos receberam nos PCN do Ensino Médio.

O aluno do ensino médio precisa e deve saber ler, interpretar, compreender e identificar os diversos gêneros discursivos para melhorar sua fala e sua escrita, além de, e principalmente, conseguir adequar os mesmos gêneros discursivos às diversas situações de comunicação às quais é constantemente submetido. Está é, portanto, a pertinência do estudo dos gêneros discursivos na atualidade.

No segundo capítulo, discutimos um dos grandes responsáveis por uma ação consciente e justificada no aluno do primeiro ano do ensino médio: o polêmico livro didático, que deve apresentar diversidade, propostas de estudo e um sério trabalho no que diz respeito aos gêneros discursivos. Fizemos um percurso histórico a fim de conhecer as perspectivas e papel do livro didático na sala de aula. Analisamos também o Manual do Professor do livro didático que deve trazer conceitos claros e coerentes sobre os diversos gêneros discursivos presentes nas nossas práticas sociais.

No terceiro capítulo, examinamos quais os gêneros discursivos se fazem presentes nos livros didáticos selecionados e apresentamos tabelas e gráficos

Os gêneros discursivos aparecem classificados pelo tema, forma composicional e estilo, mas os autores dos livros didáticos selecionados não explicam nem caracterizam esses gêneros. Constatando-se, assim, que não 
basta colocar o aluno em contato com os gêneros discursivos, mas é preciso levá-lo ao seu completo domínio.

Apesar da pequena coletânea, foi possível observar que os Manuais do Professor dos três livros didáticos analisados, na presente dissertação, demonstram a necessidade de um trabalho com os diversos gêneros; reconhecem que o aluno deve estar preparado para as mudanças do mundo contemporâneo tendo, assim, a necessidade de ser um leitor atento e competente produtor de texto. No entanto, somente o Manual do Professor do livro Português Linguagens traz os conceitos e fundamentos teóricos necessários para um bom desempenho do professor e conseqüente desenvolvimento intelectual do aluno.

No quarto e último capítulo, por meio da interpretação e análise das estratégias e técnicas de estudo dos gêneros discursivos apresentados nos livros didáticos selecionados, pôde-se observar que os três livros oferecem ao aluno do ensino médio textos de diversas naturezas, constituindo assim uma apropriada variedade de gêneros discursivos, mas não exploram a adequação desses mesmos textos, de forma a contribuir efetivamente para o crescimento $e$ amadurecimento do indivíduo, no tocante às suas leituras e escritas.

Sem o intuito de mudar a qualidade do livro didático, esta dissertação pretende contribuir para uma visão mais abrangente do trabalho efetuado com os gêneros discursivos dentro da sala de aula de Língua Portuguesa do Ensino Médio. O livro didático, como já salientamos anteriormente, é, muitas vezes, o principal instrumento de ensino do professor, seja ele experiente ou não, por isso precisa auxiliá-lo no trabalho com os gêneros discursivos e contribuir para que o aluno seja inserido neste contexto comunicacional.

Este estudo não teve a pretensão de ser exaustivo quanto ao enfoque dos gêneros discursivos no livro didático do ensino médio, posto que muito ainda se tem que pesquisar sobre esse importante tema. 


\section{REFERÊNCIAS BIBLIOGRÁFICAS}

ABREU, A. S. A arte de argumentar:gerenciando razão e emoção. São Paulo: Ateliê Editorial, 2000.

ADAM, J-M. Textualité et séquentialité: l'exemple de la description. Langue Française, n. 74, p.51-72, 1987.

Les textes: types et prototypes. Paris: Nathan, 1992.

ANDRADE, M. L. da C. V.de O. Estratégias pragmático-discursivas e controle situacional em entrevistas. In: Dino Preti e seus temas: oralidade, literatura, mídia e ensino. São Paulo: Cortez, 2001. p.97-106.

AZEVEDO, O. A história da aprendizagem da leitura pela criança e o que a escola tem a ver com essa história. Rio de Janeiro: Nova Fronteira, 1990.

BAKHTIN, M. Questões de literatura e de estética. São Paulo: Hucitec, 1988.

Os gêneros do discurso. In: . Estética da criação verbal.Trad. do francês de Maria Ermantina Galvão Gomes Pereira. São Paulo: Martins Fontes, 1992. p. 277-326. Título original: Estetika Slovesnogo Tvortchestva, 1953.

. Marxismo e filosofia da linguagem. Trad. Michel Lahud e Yara Frateschi Vieira. 6.ed. São Paulo: Hucitec, 1992a. Título da edição original: Marksizm i filosofija, 1929.

BASTOS, N. B. Língua Portuguesa: teoria e método. São Paulo : Educ, 2000.

BATISTA, A.A. Um objeto variável e instável: textos, impressos e livros didáticos. In M.ABREU (Org.). Leitura, história e história da leitura. Campinas: Mercado de Letras/ALB, 2000.

O programa nacional do livro didático: problemas e perpectivas. São

Paulo: s.e., 2001.

BEACCO, J.C. Types ou genres? Catégorisation dês textes et didactique de la comprehension et de la production écrites. In Études de linguistique appliquée. Didactologie dês langues -cultures, didier Erudition, juillet-septembre 1991.

BEZERRA, M. A. Ensino de língua portuguesa e contextos teóricometodologógicos. In: Angela Paiva DIONÍSIO, Anna Rachel MACHADO, Maria Auxiliadora BEZERRA (Orgs.) Gêneros textuais \& ensino. 3.ed. Rio de Janeiro: Lucerna, 2005. 
BONINI, A. A noção de sequência textual na análise pragmático-textual de JeanMichel Adam. IN: MEURER, J.L.; BONINI, A.; MOTTA-ROTH, D. (Orgs.) Gêneros: teorias, métodos, debates.São Paulo: Parábola, 2005.

BOUQUET, S. Linguistique textuelle, jeux de langage et sémantique du genre. Langages. Paris: Larousse, n. 129, mars 1998.

BRAIT, B. Ironia em perspectiva polifônica. Campinas: Unicamp, 1996.

BRANDÃO, H. N. (Coord). Gêneros do discurso na escola. São Paulo: Cortez, 2000.

. Introdução à análise do discurso. 6.ed. Campinas: UNICAMP, 1997.

. Revista de Estudos Lingüísticos XXXS - GEL-FFLCH-USP, 2002.

BRONCKART, J.P. Atividade de linguagem, textos e dicursos por um interacionismo sócio-discursivo. São Paulo: EDUC, 2003.

. Interactions, discours, significations. In Langue Française, n.74, Paris: Larousse, mai 1987.

CATÁLOGO do programa nacional do livro didático para o ensino médio: PNLEM/2005: língua portuguesa. Brasília: MEC, SEMTEC, FNDE, 2004.

CEREJA, W. R.; MAGALHÃES, T. C. Português linguagens: literatura, produção de texto e gramática. São Paulo: Atual, 2004.

CHIAPINI, L. A circulação dos textos na escola. IN.: BRANDÃO, H.N. Gêneros do discurso na escola. São Paulo: Cortez, 2000, p.9-15.

CORACINI, M.J. Um fazer persuasivo: o discurso subjetivo da ciência. Campinas: Pontes, 1991.

Pontes, 1999.

(Org.) Interpretação, autoria e legitimação do livro didático. Campinas/SP:

COSTE, D. O texto: leitura e escrita. Campinas: Pontes, 1997.

Genres de textes et modes discursifs dans l'enseignement/appentissage dês langues. In Études de linguistique apliquée. Didactologie dês langues-cultures, didier Erudition, juillet-septembre 1991.

CRISTOVÃO, V. L. L. Gêneros e ensino de leitura em le: os modelos didáticos de gêneros na construção e avaliação de material didático. Tese (Doutorado em Lingüística Aplicada e Estudos da Linguagem). Pontifícia Universidade Católica, São Paulo, 2001. 
DE NICOLA, J. Língua, literatura e produção de textos. São Paulo: Scipione, 2005. DIONÍSIO, A. P.; BEZERRA, M. A. O livro didático de português: múltiplos olhares. 2.ed. Rio de Janeiro: Lucerna, 2003.

; MACHADO, A. R.: BEZERRA,M. A. Gêneros textuais \& ensino.3.ed. Rio de Janeiro: Lucerna, 2005.

DOLZ, J.; SCHNEUWLY, B. Gêneros e progressão em expressão oral e escrita. Trad. Roxane H.R.Rojo. Mimeografado, 1999.

ESTEFOGO, F. Reflexão crítica: caminhos para novas ações. Dissertação de mestrado. São Paulo: Lael/PUCSP, 2001.

FARACO, C. E.; MOURA, Francisco Marto. Língua e literatura. São Paulo: Ática, 2002.

FAVERO, L.L.; ANDRADE, M.L.C.V.O; AQUINO, Z.G.O. Oralidade e escrita: perspectivas de língua materna. São Paulo: Cortez, 1999.

FIORIN, J.L. As astúcias da enunciação: as categorias de pessoa, espaço e tempo. São Paulo: Ática, 1996.

FREITAG, B., COSTA, W. F.da; MOTTA, V. R. O livro didático em questão. São Paulo: Cortez, 1989.

GARCIA, O.M. Comunicação em prosa moderna: aprendendo a escrever, aprendendo a pensar. 11.ed. Rio de Janeiro: FGV, 1983.

GAVAZZI, S.; EDUARDO, S. Lugares/valores argumentativo no ensino médio. In: Da língua ao discurso: reflexões para o ensino. Rio de Janeiro: Lucerna, 2005.

GERALDI, J. W. Portos de passagem. 2.ed. São Paulo: Martins Fontes, 1993.

GOMES JÚNIOR, S. C.. À margem da confluência: a relação oralidade x escrita no livro didático de português (ensino fundamental $-5^{\mathrm{a}}$ a $8^{\mathrm{a}}$ série). Dissertação de Mestrado. São Paulo: USP, 2005.

GRILLO, S. V. de C. Formas de produção do real na imprensa brasileira: greve dos petroleiros e gêneros do discurso nos jornais Folha de S. Paulo e o Estado de São Paulo. Tese. Universidade de São Paulo, São Paulo, 2001.

; CARDOSO, F. M. As condições de produção dos gêneros discursivos em atividades de leitura de livros didáticos de língua portuguesa do ensino fundamental. In: Livro didático de língua portuguesa, letramento e cultura escrita. Campinas: Mercado de Letras, 2003. 
HILGERT, J.G. "A construção do texto 'falado' por escrito na Internet". In: PRETI, D. (Org.). Fala e escrita em questão. São Paulo: Humanitas, 2000.

HOLANDA, G. Programas e compêndios de história para o ensino secundário brasileiro de 1930 a 1956. Rio de Janeiro: INEP?MEC, 1957.

JACOBSON, R. Lingüística e comunicação. 3.ed. São Paulo: Cultrix, 1970.

KLEIMAN, A.. Oficina de leitura: teoria e prática. 9.ed. Campinas:UNICAMP, 2002. 2002. Texto e leitor: aspectos cognitivos da leitura. 8.ed. Campinas: Pontes,

KOCH, I. V.; FÁVERO, L. L. Discurso e referência. São Paulo: Alfa, 1984.

MACHADO, I.A. O romance e a voz. Rio de Janeiro: Imago/Fapesp, 1995.

MACHADO, A. R. Gêneros e tipos de discurso. In Estudos Lingüísticos XXVII. Grupo de Estudos Lingüísticos do Estado de São Paulo. UNESP-IBILCE. São José do Rio Preto, 1998.

A perspectiva interacionista sociodiscursiva de Bronckart. In: MEURER, J.L.; BONINI, Adair, MOTTA-ROTH, Desirée. Gêneros, teorias, métodos, debates. São Paulo: Parábola Editorial, 2005.

MAINGUENEAU. D. Genèses du discours. Bruxelles: Pierre Mardaga, 1984. Novas tendências em análise do discurso. 2.ed. Campinas:

Pontes/UNICAMP, 1989.

MARCUSCHI, L. A. Da fala para a escrita: atividades de retextualização. 2.ed. São Paulo: Cortez, 2001.

Oralidade e ensino de língua: uma quetão pouco "falada". In: DIONÍSIO, A. P.; BEZERRA, M. A. O livro didático de português: múltiplos olhares. 2.ed. Rio de Janeiro: Lucerna, 2003.

Gêneros textuais: definição e funcionalidade. In: MACHADO, Anna Rachel: BEZERRA,Maria Auxiliadora. Gêneros textuais \& ensino.3.ed. Rio de Janeiro: Lucerna, 2005.

MARCUSCHI, E. Os destinos da avaliação do manual do professor. In: DIONISIO, Angela Paiva; BEZERRA, Maria Auxiliadora. O livro didático de português:

múltiplos olhares. 2.ed. Rio de Janeiro: Lucerna, 2003. 
MEURER, J. L.; MOTTA-ROTH, D. (Org.). Gêneros textuais e práticas discursivas: subsídios para o ensino da linguagem. Bauru/SP: EDUSC, 2002.

MUNAKATA, K. Livro didático: Produção e leituras. In: ABREU, M. (Org.) Leitura, história e História da leitura. Campinas: Mercado de Letras/ALB, 2000.

NEVES, M. H. de M. Gramática de Usos do Português. São Paulo: UNESP, 2000.

ORLANDI, E.P. Análise do dirscurso: princípios e procedimentos. 2.ed. Campinas: Pontes, 2000.

A linguagem e seu funcionamento: as formas do discurso. Campinas:

Pontes, 1983.

PCN: Apresentação da área de Língua Portuguesa: Introdução. Brasil: 1997. Brasil: 1999.

PÈCHEUX, M. O discurso: estrutura ou acontecimento. Trad. E.P.Orlandi. Campinas: Pontes, 1990.

PERRENOUD, P. Construir competências desde a escola. Porto Alegre: Artes Médicas, 1999.

POSSENTI, S. Discurso, estilo e subjetividade. São Paulo: Martins Fontes, 1988.

QUEIRÓS, Bartolomeu Campos. As circunstâncias da escrita para jovens. Em conferência de abertura do $1^{\circ}$.COLE, UNICAMP / Campinas, 05 jul.2005.

RIZZO, S. Clássico é Clássico. Educação. São Paulo: Segmento, Ano 28, no. 242, junho de 2001.

ROJO, R. H.R. Perspectivas enunciativo-discursivas em produção de textos. Anais do IV Concresso de Lingüística Aplicada. Campinas: DLA/IEL/ÜNICAMP, 1996.

; BATISTA, A. A. G. (Orgs.) Livro didático de língua portuguesa, letramento e cultura escrita. São Paulo: Mercado de Letras, 2003.

Gêneros do discurso e gêneros textuais: questões teóricas e aplicadas. In: MEURER, J.L.; BONINI, A.; MOTTA-ROTH (Orgs.). Gêneros: teorias, métodos, debates. São Paulo: Parábola Editorial, 2005.

SCHNEUWLY, B.; DOLZ, J. Os gêneros escolares: das práticas de linguagem aos objetos de ensino. In: Gêneros orais e escritos na escola. Tradução e organização de Roxane Rojo e Glaís Sales Cordeiro. Campinas/SP: Mercado de letras, 2004. 
SIMONIN-GRUMBACH, J. Pour une typologie des discours. In KRISTEVA, J. et al. Langue, discours, société. Paris: Seuil, 1975.

SOUZA, G.T. Introdução à teoria do enunciado concreto do círculo

Bakhtin/Volochinov/Medvedev. São Paulo: Humanitas FFLCH/USP, 1999.

SOUZA, D. M. Autoridade, autonomia e livro didático. In: CORACINI, Maria José (Org.). Interpretação, autoria e legitimação do livro didático. São Paulo: Pontes, 1999.

TODOROV, T. Os gêneros do discurso. São Paulo: Martins Fontes, 1980.

URBANO, H. Aspectos basicamente interacionais dos marcadores discursivos. In: NEVES, Maria Helena de Moura. Gramática do português falado. São Paulo:Humanitas, 1999.

VANOYE, F. Usos da linguagem: problemas e técnicas na produção oral e escrita. São Paulo: Martins Fontes, 1973.

VIGNER, G. Técnicas de aprendizagem da argumentação escrita. In O texto: leitura e escrita. Campinas: Pontes, 1988. 